$\int_{\mathcal{G}}^{\text {Semantics \& Pragmatics Volume 8, Article 3: 1-103, } 2015}$

\title{
The role of givenness, presupposition, and prosody in Czech word order: An experimental study*
}

\author{
Radek Šimík \\ University of Potsdam/SFB632
}

\author{
Marta Wierzba \\ University of Potsdam/SFB632
}

Submitted 2014-02-28 / First decision 2014-06-19 / Revision received 2014-07-09 /

Accepted 2014-07-16 / Final version received 2014-08-13 / Published 2015-01-14

\begin{abstract}
We present evidence from acceptability judgment experiments that there is systematic prosodic givenness marking in Czech in that discourse-salient elements avoid sentence stress, contra the claim in Kučerová 2007, 2012 that givenness is marked only syntactically — by establishing a word order in which all given elements precede all new ones - and not prosodically in Czech. We argue that the syntactic movement of given elements results from the need to avoid the rightmost position where sentence stress falls, and not from a syntactic ordering requirement. This is supported by the empirical finding that given objects need not scramble if they are not in sentence-final position, even if they are preceded by new elements (experiment 2). We also argue against Kučerová's claim that given elements are marked only if definite/presupposed in Czech by showing that irrespective of this property, all given objects tend to avoid the sentence-final position (experiment 1). Finally, our results reveal an interaction between presupposition and word order, in the sense of an acceptability penalty for utterances in which non-
\end{abstract}

* We are grateful to the following people for their valuable comments: Philippa Cook, Gisbert Fanselow, Jana Häussler, Beste Kamali, Ayesha Kidwai, Ivona Kučerová, Frank Kügler, Agata Renans, Michael Rochemont, Filip Smolík, Kriszta Szendrői, Barbara Tomaszewicz, Luis Vicente, Malte Zimmermann. Parts of this paper were presented in preliminary versions on two occasions: in a seminar on the relation between information structure and syntax in Potsdam (January 2012) and at the Formal Approaches to Slavic Linguistics 22 at McMaster University (May 2013). We thank the audiences for their comments. The paper has undergone significant revision during the review process. We are grateful to the anonymous reviewers and the editors of Semantics \& Pragmatics, esp. Paul Elbourne, for their incredibly valuable comments and questions. Finally, we'd like to express our gratitude to the following people for their help with the data and experiments: Dan Faltýnek, Anna Koubová, Eva Lehečková, Marcela Mikulková, Jiří Neděla, Veronika Pleskotová, Hana Strachoňová, Veronika Šimíková Vlachová, Tereza Štěpánová. All remaining errors are ours.

(C)2015 Šimík \& Wierzba

This is an open-access article distributed under the terms of a Creative Commons Attribution License (http://creativecommons.org/licenses/by/3.o/). 
presupposed expressions precede presupposed ones (experiment 1 and 2). We propose to model the results by a set of weighted constraints that apply post-derivationally.

Keywords: givenness, presupposition, prosody, Czech, scrambling, acceptability judgments, experiments

\section{Introduction}

This paper intends to contribute to the discussion of givenness and definiteness in Czech and their effects on sentence form, in particular word order and prosody. According to a recent approach (Kučerová 2007, 2012), Czech has a special way of grammatically marking givenness. Whereas other intonation languages like English or German make use of deaccentuation, Czech uses syntactic movement to mark an element as given. According to Kučerová (2007, 2012), a further difference between the two types of givenness marking is that in Czech, givenness is marked only if combined with definiteness or presupposition, whereas in English, discourse-salience alone licenses deaccenting.

In this paper, we use controlled acceptability judgment experiments to argue that Czech does in fact have a system of prosodic givenness marking that is very similar to the one found in English or German, and which is independent of definiteness/presupposition. We argue that the need to deaccent given elements can motivate movement away from the sentence-final position, where default sentence stress falls. The evidence for this position consists of the following experimental findings:

i. there is a clear relation between givenness and sentence stress in Czech;

ii. given objects scramble even if they are indefinite (non-specific); and

iii. given objects (both definite and indefinite) need not scramble at all if they are not in the sentence-final position, where they would receive sentence stress.

Despite the finding that definiteness/presupposition is not a necessary condition for scrambling, we do find an interaction between presupposition 
The role of givenness, presupposition, and prosody in Czech word order

and word order: we find a significant penalty for structures in which non-presupposed expressions precede presupposed ones. However, we argue that this can be conceptualized as an additional effect on top of the prosodygivenness interaction that motivates scrambling.

We propose to model the findings by three constraints that apply postderivationally at the interface-level: *STRESS-GIVEN prohibits given elements from carrying sentence stress, NSR-I requires sentence stress to fall on the rightmost element, and *NON-PRES $>$ PRES penalizes structures in which non-presupposed elements precede presupposed ones. Each constraint is associated with a certain weight; these weights add up in a cumulative way to model acceptability contrasts between structures depending on the constraint violations in which they differ: a violation of *STRESS-GIVEN causes a decrease in acceptability in comparison to a structure that does not violate it which amounts to an effect size around $\delta=0.6$ in terms of Cliff's $\delta$ (Cliff 1993, 1996) and would correspond to a "large effect" in Cohen's (1988) categorization of effect sizes, whereas a violation of one of the other two constraints causes a decrease corresponding to a "small" to "medium effect" (Cliff's $\delta$ between 0.2 and 0.3 ).

We find the findings interesting in at least three respects. First, they show the relevance (and in a way primacy) of prosody for information structure, and givenness in particular, in a language that was considered a "discourse configurational language" long before this term was introduced (e.g., Mathesius 1939). Second, they show that there is a relation between definiteness and word order, which partly corroborates the proposal of Kučerová $(2007,2012)$. At the same time, however, we will show that her proposal is problematic in a number of respects. Third, our conclusion that presupposition interacts directly with word order, but givenness does so only indirectly via prosodic constraints, is in line with the analysis of German scrambling proposed by Fanselow (2012) (where it is definiteness rather than the informationstructural property of givenness that is linked to word order), and more generally with the view that there is no direct relation between word order and information structure related features, a position defended by Horváth (2010), among others.

The paper is structured as follows. In Section 2 we introduce the core notions discussed in this paper: definiteness, presupposition, and givenness. In Section 3 we discuss two existing approaches to givenness-related word order alternations: the grammatical approach of Kučerová (2007, 2012), according to which givenness is marked by means of word order, and a prosodic approach, 
according to which givenness is marked prosodically (via *STRESS-GIVEN) and only secondarily by word order (via NSR-I). We also briefly discuss the possibility of a multi-factorial approach, according to which a word order restriction and a prosodic restriction could both jointly contribute to word order alternations. It is the last kind of approach that we end up defending in this paper. Section 4 discusses the experiments that we performed to test the two hypotheses. We will show that neither hypothesis can explain the results completely. In Section 5 we discuss a number of potential confounds that could in principle have had an impact on the experimental results. In Section 6 we provide a general discussion of the results and their relation to the examined hypotheses. We conclude that the prosodic hypothesis is in principle better suited to model the results but needs to be supplemented by an independent word order-based restriction. Our proposal as to how the results should be modeled is presented in Section 7. We use Linear Optimality Theory, which allows us to capture the gradience in our results, and argue that three constraints are instrumental in explaining them: *STRESS-GIVEN (relating givenness to prosody), NSR-I (relating prosody to word order), and *NON-PRES $>$ PRES (relating presupposition to word order). Section 8 concludes the paper.

\section{Theoretical and empirical background}

In this section we provide some necessary background on definiteness and givenness. Definiteness is discussed mainly in order to introduce the way it is marked (or not marked) in Czech. Givenness is discussed in order to avoid any terminological confusion and only using English as an example. Givenness marking in Czech is a controversial issue and will be discussed in the rest of this paper.

\subsection{Definiteness and presupposition}

We understand definiteness in terms of the presupposition of uniqueness. ${ }^{1}$ More particularly, a definite NP is associated with the presupposition that

1 We only provide a very rough sketch of this approach to definiteness. Also, we do not discuss prominent competing theories, in particular the Russellian view that uniqueness is asserted rather than presupposed (Russell 1905) and the treatment of definiteness in terms of familiarity (Christophersen 1939, Kamp 1981, Heim 1982). For a thorough discussion of the presuppositional approach and arguments in its favor we refer the reader to Elbourne 2013. 
The role of givenness, presupposition, and prosody in Czech word order

there is exactly one entity that satisfies the NP descriptive content (Frege 1892). If this presupposition is satisfied, the definite NP denotes that entity. If not, the denotation of the definite NP is undefined. ${ }^{2}$ This is illustrated by the contrast between (1a) and (1b). While the capital of Sweden has a well defined denotation (it denotes Stockholm), this is not necessarily the case with the town in Sweden. That is, while the presupposition of uniqueness is satisfied in (1a), this is not the case in (1b). This is not to say, of course, that the town in Sweden never has a denotation. If the NP contains a phonologically null property variable (see von Fintel 1994), whose value (say 'northernmost') intersects with the value of the overt material (giving rise to the property 'northernmost town in Sweden'), it might very well be the case that the presupposition of uniqueness is satisfied and the expression has a denotation (Kiruna in this case).

a. The capital of Sweden is flooded.

b. The town in Sweden is flooded.

In English, definite NPs are obligatorily marked by a definite article (or another definite determiner). Czech, on the other hand, has no grammaticalized expression of definiteness. The sentence that corresponds to the English (1a) is expressed with no marking at all:

(2) Hlavní město Švédska je zaplavené. main town.NOM Sweden.GEN is flooded 'The capital of Sweden is flooded.'

More generally, whether an expression is interpreted as definite or indefinite in Czech depends on various lexical, grammatical, discourse-related, and world-knowledge-related factors. Consider the example in (3). As indicated by the English translation, the bare nominal kreslo 'chair' can be interpreted both as definite and as indefinite. The indefinite interpretation will be salient if Karel has entered a room full of empty chairs. Since the presupposition that there is a single chair is not satisfied in such a situation, no definite interpretation of kreslo 'chair' is possible. (Accordingly, the use of the chair in English would be infelicitous.) The definite interpretation will be salient if the room that Karel has entered is a dentist's office and the chair Karel sat

2 We use NP as a shorthand for both NP and DP (in Abney's (1987) terms) and remain agnostic as to whether Czech (or more generally Slavic) NPs have or lack the D(eterminer) syntactic category. For some discussion see Pereltsvaig 2007 and Bošković $2009 a$. 
down on is a dentist's chair. Since it is usual that there is a single dentist's chair in a dentist's office, the presupposition of a single chair is satisfied and consequently the definite interpretation is salient (and the use of a definite article in English is felicitous).

(3) Karel vstoupil, posadil se na křeslo a čekal. Karel.NOM entered sat.down REFL on chair.ACC and waited 'Karel entered, sat down on a/the chair, and waited.'

Besides discourse-, context- or world-knowledge-based resolution of the (in)definiteness of a noun phrase, Czech has a range of determiners, which typically unambiguously mark the noun phrase they attach to as indefinite or definite. For example, the determiners nějaký 'some' and ten 'that', illustrated below (italicized for clarity), go hand in hand with indefinite and definite interpretation, respectively. In (4) no single brewery is mentioned in the discourse and accordingly, it is infelicitous to use the definite determiner ten. ${ }^{3}$ On the other hand, the use of an indefinite determiner nějaký is perfectly natural. In (5) the presupposition needed for a definite interpretation is satisfied - there is a particular brewery that the participants have in mind and consequently, the use of the definite determiner is licensed. The use of the indefinite determiner is possible, too, but it signals that the brewery that Karel visited is different than the one talked about. ${ }^{4}$ Finally, both in (4) and in (5), the use of a bare noun (introduced by $\emptyset$ for ease of comparison with the determiners) is felicitous, and, as expected, the most salient interpretation is an indefinite one for (4) and a definite one for (5).

(4) Plánovali jsme výlet a bavili jsme se planned AUX.PAST.1PL trip.ACC and talked AUX.PAST.1PL REFL o různých vinárnách a pivovarech. Karel about various wine.cellars.LOC and breweries.LOC Karel.NOM nakonec navštívil nějaký /\# ten / Ø pivovar. in.the.end visited some / that / brewery.ACC

'We were planning a trip and we talked about various wine cellars and breweries. In the end, Karel visited a/the brewery.'

3 We assume that the determiner is definite because it behaves in many respects as a demonstrative and it has recently been argued (convincingly, in our view) that demonstratives are indeed are definites of sorts; see Roberts 2002, Elbourne 2008.

4 This is the standard novelty condition on referents introduced by indefinite descriptions; see Heim 1982. 
The role of givenness, presupposition, and prosody in Czech word order

(5)
Plánovali jsme
výlet a bavili jsme
se planned AUX.PAST.1PL trip.ACC and talked AUX.PAST.1PL REFL o jedné vinárně a jednom pivovaru. Karel about one wine.cellar.LOC and one brewery.LOC Karel.NOM nakonec navštívil nějaký / ten / Ø pivovar. in.the.end visited some / that / brewery.ACC 'We were planning a trip and we talked about a certain wine cellar and a certain brewery. In the end, Karel visited a/the brewery.'

As will become clear later on, the possibility to resolve the definiteness of a NP contextually is used in our experiments to form minimal pairs with no formal difference in definiteness marking.

\subsection{Givenness}

Just like other information-structural notions, the term "givenness" has been used in many different ways. (See E. Prince 1981 for an early overview.) We follow the line of thought represented by Rochemont (1986), Schwarzschild (1999), and Wagner (2012), among others, according to whom givenness corresponds to discourse salience: an expression is given if there is a proper antecedent for it in the discourse. What it is to be a "proper antecedent" will be discussed shortly. In English, given expressions cannot realize the main stress in a certain domain. ${ }^{5}$ Since we will only be interested in the clausal domain, it is sufficient to say that given expressions avoid the main stress in the intonation phrase domain (roughly corresponding to a clause). This often leads to the so called stress shift - a situation where the default stress realization is overridden in order to satisfy the requirement that given expressions not be stressed (see, e.g., Reinhart 1995, 2006). Consider example (6): in (6B) can speak French is given because of the presence of the antecedent can [...] speak French in (6A). As a consequence, even though can speak French would by default contain the sentence stress (realized on French), the stress is shifted to a non-given part of the sentence, namely John. We indicate sentence stress by boldface and givenness by underlining.

$$
\begin{aligned}
& \text { A: Can anybody speak French? } \\
& \text { B: John can speak French. }
\end{aligned}
$$

5 As correctly pointed out by an anonymous reviewer, this is only true of given expressions that are not focused at the same time. We kindly ask the reader to always read "given" as "given and not focused". 
Let us get back to what it means to be a "proper antecedent" for a given expression. This depends on the semantic type of the evaluated expression: for entities, the meaning of the antecedent must be equal to the meaning of the evaluated expression, see (7a); for functions, the $\exists$-type shifted version of the evaluated expression must be entailed by the $\exists$-type shifted version of the antecedent, see $(7 \mathrm{~b}){ }^{6,7}$

(7) Given

An utterance $U$ counts as given iff it has a salient antecedent $A$ and

a. if $U$ is of type $e$, then $A$ and $U$ corefer;

b. otherwise: modulo $\exists$-type shifting, $A$ entails the existential Fclosure of $U .^{8}$

In this approach to givenness, almost any kind of meaningful linguistic expression can be given. This includes a referential argument (type $e$ ), as in (8), a non-referential expression contained in an argument (type $\langle e, t\rangle$ ), as in (9), or a predicate (type $\langle e, t\rangle)$, as in (10). ${ }^{9}$

a. Context: I thought about John yesterday. I decided to call him.

b. $\quad \llbracket$ him $_{4} \rrbracket^{g}=\llbracket \mathrm{John} \overline{\rrbracket^{g}}$

(9) a. A: Did you see any octopus?

B: I didn't look for an octopus.

b. $\exists x$.octopus $(x)$ entails $\exists \overline{x \text {.octopus }}(x)$

6 Schwarzschild's definition of givenness can only account for expressions of type $e$ and functions whose type "ends in" $t$. It is not our ambition to extend the approach to other expressions.

7 Wagner $(2006,2012)$ argues that Schwarzschild's entailment condition is too weak: the givenness of an expression must be evaluated relative to its sister, which must be focused in the sense of Rooth 1992. As we will show in Section 5.5, our experimental results seem to support Wagner's stronger condition.

$8 \exists$-type shifting is, to put it simply, an operation that replaces expression-initial lambdas by $\exists$ (e.g., $\lambda x$.apple $(x)$ turns into $\exists x$.apple $(x)$ ). Existential F-closure is a two-step operation, which first replaces focused expressions by variables of the same type and then binds them existentially. We are not concerned with given expressions that contain focused constituents and the F-closure part of the definition could therefore be ignored for the purpose of this paper.

9 Predicates with more than one argument can easily be subsumed under the above definition if they are "de-Schönfinkelized" - that is, if all the arguments are turned into a single argument tuple, turning, for instance, a two-place predicate into a one-place predicate with pairs of entities in its extension. 
The role of givenness, presupposition, and prosody in Czech word order

(10) a. A: Does one of them play the guitar?

B: I hear that Tom is musical.

b. $\exists x$.play the guitar' $(x) \overline{\text { entails } \exists} x$.is musical $(x)$

An important consequence of this approach is the clear dissociation of givenness - presupposition of discourse salience - from the standard presupposition of truth (see Wagner 2012 for a good recent discussion). A definite NP is not necessarily given and, conversely, a given NP is not necessarily definite in that it need not presuppose the existence of a (unique) referent. The latter case is illustrated by (9), where octopus is given despite the fact that it is not definite. Examples of non-given definite NPs are abundant and include all the newly mentioned unique definites such as the President of the US, the capital (of Sweden), and so on. Indeed, if these are mentioned for the first time in a discourse, they can realize sentence stress.

(11) A: What are you going to do in Sweden?

B: We want to visit the capital.

An analogous difference can be observed for expressions of other types. (Complements of factive verbs need not be given, given complements of non-factive verbs don't give rise to a presupposition, etc.)

The formal expression of givenness in Czech is a controversial issue. A common assumption is that givenness somehow relates to word order but the question is whether it does so directly or through prosody.

\section{Approaches to givenness-related word order alternations}

In this section we first describe two existing approaches to givenness-related word order alternations: the grammatical approach recently proposed by Kučerová (Subsection 3.1) and a prosodic approach, according to which word order alternations are driven by prosodic considerations (Subsection 3.2). We then move on to a third possible approach (Subsection 3.3), anticipating our own proposal in Section 7, which attributes givenness-related word order alternations to more than just a single factor.

\subsection{Kučerová's grammatical approach}

Our experiments are partly designed to test the predictions of a recent approach to Czech word order alternations - the grammatical approach of 
Kučerová $(2007,2008,2012)$ (Ko7, Ko8, K12 for short). In this section, we discuss Kučerová's approach in some detail in order for the readers to be able to evaluate its predictions for themselves. Whenever possible, we stick to the most recent formulation of her theory $\left(K_{12}\right)$, yet, we will often refer to her dissertation (Ko7), which is more specific about issues that are not explicitly discussed in the more recent paper. We would also like to point out that some aspects of Kučerová's theory are modified in the exposition below. Modifications are always announced and are limited to cases where the original formulations are technically problematic in one way or another. Also, we try to make sure that our modifications do not alter the empirical predictions that Kučerová intends to make.

\subsubsection{Given+presupposed: Kučerová's notion of givenness}

Kučerová proposes that a certain semantic/pragmatic property is grammatically marked in Czech. (We will discuss how this marking is realized in the next section.) She calls this property "givenness" (in Ko7), but makes clear that it is not identical with the property that is marked by deaccentuation in English (discourse-salience). The condition on grammatical marking in Czech is stronger: on top of having a discourse antecedent, the marked elements are also required to be "presupposed" (Ko7:127-128, K12:18), a condition that is satisfied by expressions that are definite or specific (in Enç 1991's sense of implicit partitivity) but not expressions that are non-specific. In order to keep the two notions of givenness apart, we continue using the term givenness in its weaker sense only, that is, in the sense of discourse-salience defined in Section 2.2. For Kučerová's "givenness", we use the somewhat clumsy but precise term given+presupposed. ${ }^{10}$ The definition of given+presupposed is in (12) (adapted from Schwarzschild 1999 by strengthening his (bi) by (bii)). ${ }^{11}$

10 Not all given+presupposed expressions are grammatically marked as such in Czech, according to Kučerová. Some, such as personal pronouns, are lexically marked as given+presupposed and consequently require no grammatical marking. In this paper, we are not concerned with lexically marked given+presupposed expressions in a way that would require any deeper discussion.

11 There is one major departure from Kučerová's original formulation. (We are grateful to Paul Elbourne and an anonymous reviewer for drawing our attention to the problems with the original formulation; the formulation in (12) is our own, just as all the potential remaining errors in it.) In particular, the condition in (12b-ii) is originally formulated as "it is presupposed that $U$ exists". However, such a condition is trivial in that discourse participants always presuppose that their utterances exist. Certainly, it does not have the 
The role of givenness, presupposition, and prosody in Czech word order

Given+presupposed

(adapted from Ko7:127)

An utterance $U$ counts as given+presupposed iff it has a salient antecedent $A$ and

a. if $U$ is of type $e$, then $A$ and $U$ corefer;

b. otherwise:

(i) modulo $\exists$-type shifting, $A$ entails the existential F-closure of $U$, and

(ii) the denotation of $U$ characterizes a familiar set of entities/properties/relations/...

In order to illustrate how (12) works, consider the simple example in (13) and the conditions on the givenness+presupposition of linguist, (13a), and invited, (13b).

(13) Dave invited a linguist.

a. The utterance linguist (of type $\langle e, t\rangle$ ) counts as given+presupposed iff it has a salient antecedent $A$ (e.g., syntactician) and it holds that $\exists x \cdot A^{\prime}(x)$ entails $\exists x$.linguist ${ }^{\prime}(x)$ and the function that linguist maps to $\left(\lambda x\right.$.linguist $\left.^{\prime}(x)\right)$ characterizes a familiar set of linguists.

b. The utterance invited (of type $\langle e,\langle e, t\rangle\rangle$ ) counts as given+presupposed iff it has a salient antecedent $A$ (e.g., invited) and it holds that $\exists x, y \cdot A^{\prime}(x, y)$ entails $\exists x, y$.invited $(x, y)$ and the function that invited maps to $(\lambda x . \lambda y$.invited $(x, y))$ characterizes a familiar set of invitee-invited pairs.

A prototypical example of an expression that is grammatically marked as given+presupposed in Czech is, according to Kučerová, an anaphoric definite $\mathrm{NP}$, such as lízátko 'the lollipop' in (14b). We use double underlining to

effect intended by Kučerová, who merely wants to say that a given+presupposed indefinite NP is interpreted as (implicitly) partitive. Kučerová does not offer a theory of partitivity, but she seems to rely on Enç (1991), who in turn builds on Heim's (1982) theory of familiarity. The idea is that an indefinite is interpreted as (implicitly) partitive if the referent that is intended to verify the statement belongs to a familiar set of referents. Our formulation (12b-ii) intends to generalize partitivity to " $t$-ending" functions of any type, so that the property of being given+presupposed can also apply to, say, transitive verbs. Finally, we assume that an analogous familiarity condition is satisfied trivially for given+presupposed $e$-type expressions, (12a), as these corefer with expressions from the previous discourse and in that sense, their referents are familiar. 
indicate givenness+presupposition and continue using single underlining for the weaker notion of givenness.
a. girl.NOM lost
la na cestě
do školy
lízátko.
A pak...
then
'A girl lost a lollipop on her way to school. And then...'
b. lízátko našel chlapec.
lollipop.Acc found boy.NOM
'A boy found the lollipop.'
$(K 12: 3 / 6)$

Let us see why lízátko 'lollipop' counts as given+presupposed in (14b). Suppose it is of type $e$ : it refers to a particular lollipop. Then, it is sufficient if there is an antecedent with which lízátko 'lollipop' in (14b) is coreferent. Lízátko 'lollipop' in (14a) is the suitable candidate.

According to Kučerová, the requirement on having a salient antecedent in the discourse is a necessary one, as a consequence of which not every definite description is grammatically marked as given+presupposed in Czech (see Ko7:128) If (15) is uttered out of the blue, for instance, the definite NP královnou 'the queen' is not given+presupposed.

(15) Král včera hrál šachy s královnou. king.NOM yesterday played chess.ACC with queen.INSTR

'The king and the queen played chess yesterday.'

$($ Ko7:128)

The type of case where givenness+presupposition differs from mere givenness is illustrated in (16). Suppose that Porsche in (16B) is of type $\langle e, t\rangle .^{12}$ Since the set of Porsches that it characterizes is not a familiar one (any unfamiliar Porsche could verify the statement), the condition (12b-ii) is not satisfied, and the expression Porsche in (16B) does not count as given+presupposed. The formal consequence of this is that the fronting of Porsche is

12 Depending on one's favorite analysis of "weak NPs" and of have-sentences, Porsche in (16B) could either function as an argument of má 'have' directly or it could first undergo some type shifting, be it lowering to an individual-type or raising to a quantifier-type. We remain noncommittal about this issue. 
The role of givenness, presupposition, and prosody in Czech word order

not licensed in this case, cf. (16B) vs. $\left(16 B^{\prime}\right) .{ }^{13}$ We will get to the formal effect of givenness+presupposition shortly.

(16) A: Do you happen to know someone who owns a Porsche?

B: Kamarád mojí ženy má Porsche.

friend.NOM my wife.GEN has Porsche.ACC

'A friend of my wife has a Porsche.'

B':\#Porsche má kamarád mojí ženy.

Porsche.ACC has friend.NOM my wife.GEN

'A friend of my wife has a Porsche.'

(Ko7:126-127)

The example above contrasts with (17), where there is a familiar group of Porsches in the discourse. In this case $(17 \mathrm{~B}) /\left(17 \mathrm{~B}^{\prime}\right)$ involves an implicitly partitive use of Porsche (i.e., 'one of the Porsches that you had'). Partitive indefinites, according to Kučerová, do count as given+presupposed. ${ }^{14}$ The formal effect of this is that Porsche in $(17 \mathrm{~B}) /\left(17 \mathrm{~B}^{\prime}\right)$, in contrast to the previous example, must undergo fronting. ${ }^{15}$

(17) A: I've heard that you finally sold all the used cars from your store. You also had several Porsches, right? Do you remember who bought a Porsche?

B: Porsche si např́klad koupil kamarád mojí ženy. Porsche.ACC REFL for.example bought friend.NOM my wife.GEN 'For example, a friend of my wife bought a Porsche.'

$\mathrm{B}^{\prime}$ : \#Kamarád mojí ženy si napríklad koupil Porsche. friend.NOM my wife.GEN REFL for.example bought Porsche.ACC 'For example, a friend of my wife bought a Porsche.' (Ko7:126)

13 The judgments of (16) are from Kučerová. According to the native-speaker intuition of RŠ, $\left(16 \mathrm{~B}^{\prime}\right)$ is perfectly acceptable in this context or in fact the preferred option, provided that sentence stress is realized on ženy. (16B) is only acceptable if the main stress is realized on ženy 'wife', just like in English. An anonymous reviewer points out that Kučerová's judgment of $\left(16 \mathrm{~B}^{\prime}\right)$ could be due to a different implicit stress placement (e.g., on Porsche). Indeed, in this case, $\left(16 \mathrm{~B}^{\prime}\right)$ is infelicitous according to RŠ's intuition. Yet, provided that implicit stress placement is default (i.e., rightmost; see Fodor 2002), we find it unlikely that wrong stress placement would account for Kučerová's judgment of (16B').

14 More precisely, Kučerová says that "[t]he partitive semantics seems to be independent of givenness even though it is a precondition for an indefinite to be treated as given." (Ko7:127) 15 Also here, the intuition of RŠ differs slightly: $\left(17 \mathrm{~B}^{\prime}\right)$ is also acceptable provided that the main stress is realized on ženy 'wife'. 
In summary, only a proper subset of the nominal expressions that count as given in English count as given+presupposed in Czech according to Kučerová. Like in English, all must have a salient antecedent but on top of that they must either be definite or (implicitly) partitive.

\subsubsection{The given-new partition of the Czech clause, the $G$-operator, Maxi- mize Presupposition and presupposition failure}

Kučerová argues that the following generalization holds for Czech. ${ }^{16}$

Generalization I: *New $\succ$ Given+presupposed (adapted from K12:15) Within [wp Y ... X ...], where WP is of type $\langle s, t\rangle$, if $\mathrm{X}$ is given+presupposed, so is $\mathrm{Y}$.

Schematically, the generalization corresponds to the data patterns in (19) and (20): the constituent WP (of a propositional type) must be partitioned into a given+presupposed area and the rest such that all given+presupposed expressions precede all other expressions, called "new" for convenience. (We continue using double underlining here to mark givenness+presupposition.) If there is even a single instance of a new expression preceding a given+presupposed one within the WP, the result is claimed to be unacceptable.

(19) Acceptable patterns
a. [WP X Y Z ]
b. [WP $\underline{\underline{X}}$ Y Z ]

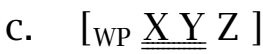
d. [wP $\underline{\underline{X} Y Z}]$

(20)

Unacceptable patterns
a. *[wP X Y Z $]$
b. *[wp X $\underline{\underline{Y Z}}]$
c. *[wp X $\underline{\underline{Y} Z}$ ]
d. *[wP $\underline{\underline{X}} \underline{\underline{Z}}]$

Kučerová accounts for the generalization by postulating an LF operator, which she calls the $G$-operator. The $G$-operator or simply $G$ operates "upwards" - its scope corresponds to whatever is not in its c-command domain. For each constituent in its scope, $G$ introduces the presupposition that that constituent is given+presupposed. Consequently, there will be as many presuppositions as there are constituents in G's scope. It follows from the Maximize Presupposition principle (Heim 1991) that all expressions that are not in the scope of $G$ will be interpreted as non-given+presupposed - that is,

16 We use WP instead of Kučerová's "Dom(ain)” and given+presupposed instead of Kučerová's "presupposed". The term "presupposed" in Kučerová 2012 is used in the same way as "given" in Kučerová 2007. 
The role of givenness, presupposition, and prosody in Czech word order

as discourse-new, non-presupposed, or both. We will say that the Maximize Presupposition principle is "violated" if the intention of the speaker was to convey that a constituent is given+presupposed but the constituent fails to be marked as such by $G$. If, on the other hand, a constituent is in the scope of $G$ and the common ground fails to support its givenness+presupposition, the resulting effect is one of presupposition failure. Kučerová's idea is that the placement of $G$, being syntactically free, is constrained just by these pragmatic considerations.

The following examples show the effect of different placement of $G$ in some of the schematic LF structures above. For the acceptable given+presupposed-before-new patterns, represented below by (21), there is exactly one position, namely between Y and Z, where $G$ can be placed without causing Maximize Presupposition violation (MPV) or presupposition failure (PF). For the unacceptable new-before-given+presupposed patterns, there is no position where $G$ could be placed without causing MPV, PF, or both: (22a) is unacceptable because $Z$ remains unmarked by $G$, $(22 b)$ is unacceptable because $Y$ is marked by $G$, and (22c) is unacceptable because $Y$ is marked and $\mathrm{Z}$ is unmarked by $G$.

[wp $\underline{\underline{X Y} Z](=(19 c))}$

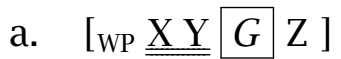

b. *[wp $\underline{X} \underline{X Y Z}] M P V$

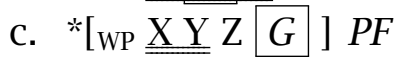

(22) $\quad *[w p \underline{\underline{X}} Y \underline{\underline{Z}}](=(20 d))$

a. *[wP $\underline{\underline{\mathrm{X}}} G \mathrm{Y} \underline{\underline{\mathrm{Z}}}] M P V$

b. *[wp $\underline{\underline{X}} Y \underline{\underline{Z}} G] P F$

c. $*$ WP $\underline{\underline{X}} Y[G[\underline{\underline{Z}}]$ both

\subsubsection{Scrambling and economy}

Scrambling or, as Kučerová calls it, " $G$-movement” can turn an unacceptable structure into an acceptable one. If we take (22), for instance, and scramble $Z$, we get either (23a) or (23b), both of which are amenable to a licit insertion of $G$.
a. [wP $\left.\underline{\underline{\mathrm{XZ}}} G \mathrm{Y} \mathrm{t}_{\mathrm{Z}}\right]$
b. $\quad\left[\mathrm{wP} \underline{\underline{Z X}} G \mathrm{Y} \mathrm{t}_{\mathrm{Z}}\right]$

Scrambling in Czech is a kind of A-movement (Ko7: Appendix A) which, similarly to the placement of $G$, is syntactically free (i.e., not feature driven; 
Ko7:58). ${ }^{17}$ Yet, it is constrained by a general economy condition which licenses it "only if it yields an interpretation that would not be available otherwise (cf. Fox 1995, 2000, Reinhart 1995).” (K12:17) A consequence of this is that even some structures that comply with the given+presupposed-before-new partition are unacceptable. This holds for structures that involve scrambling within the new area or within the given area, as illustrated below by (24a) and (24b), respectively.
a. *[wp $\left.\underline{\underline{X}} \underline{\mathrm{Z}} \mathrm{Y} \mathrm{t}_{\mathrm{Z}}\right]$
b. *[wP $\underline{\underline{\mathrm{Y} \mathrm{X} \mathrm{t}}} \underline{G} \mathrm{Z}]$

\subsubsection{The relation of givenness to prosody}

As we have showed so far, Kučerová claims that givenness+presupposition is marked grammatically in Czech. As it stands, the grammatical marking of givenness+presupposition is in principle compatible with prosodic marking of givenness of the English type. This leaves the possibility open that both grammar and prosody are involved in the marking of givenness in Czech. (We come back to this possibility in Section 3.3.) Kučerová denies this option explicitly and supports it by the following argument: if a given non-presupposed indefinite appears in the position of sentence stress, it realizes the stress without any problem. Recall that we use single underlining for givenness, double underlining for givenness+presupposition, and boldface for stress. ${ }^{18}$

17 The distinction between A- and $\mathrm{A}^{\prime}$-scrambling (based on the standard binding and scope tests) was introduced in Déprez 1989 and Mahajan 1990. Many Slavic languages have been argued to involve A-scrambling (possibly alongside $\mathrm{A}^{\prime}$-scrambling), see, e.g., Bošković 2009b for a comparison of Slavic scrambling with Japanese A'-scrambling, Slioussar 2007 for Russian, Witkoś 2007 for Polish, Biskup 2011 for Czech, or Mykhaylyk 2011 for Ukrainian.

18 The native-speaker intuition is not shared by R $\breve{S}-(25)$ sounds quite infelicitous to him. One option to make it more acceptable is shifting the stress to the verb, (ia), or (better yet) changing the word order in such a way that jezevčk ky is not sentence final, as in (ib) or (ic).

(i) a. ... ale jenom někdy důchodci trestají jezevčíky. but only sometimes pensioners.NOM punish dachshunds.ACC

'... but pensioners only sometimes punish dachshunds.'

b. ... ale jenom někdy důchodci jezevčíky trestají but only sometimes pensioners.NOM dachshunds.ACC punish

'... but pensioners only sometimes punish dachshunds.'

c. ... ale důchodci jezevčíky trestají jenom někdy. but pensioners.NOM dachshunds.ACC punish only sometimes 
The role of givenness, presupposition, and prosody in Czech word order

(25) Jezevčíci jsou obvykle nevychovaní, ale jenom někdy dachshunds.NOM are usually badly.behaved but only sometimes důchodci trestají jezevčíky. pensioners.NOM punish dachshunds.ACC

'Dachshunds are usually badly behaved but pensioners only sometimes punish dachshunds.'

(Ko7:124)

In other words, given (non-presupposed) expressions are not subject to the requirement that they not bear stress according to Kučerová. The only exception that Kučerová notes are generic plurals. In (26), the generic plural obrazy 'paintings' does not bear sentence stress: either the stress is shifted to rád 'glad', (26b), or the two constituents locally reorder and the general stress pattern obtains, (26a). ${ }^{19}$

(26) I bought a painting last week...
a. Já mám obrazy rád.
I have paintings.Acc glad 'I really like paintings.'
b. Já mám rád obrazy.
I have glad paintings.ACC
'I really like paintings.'

$($ Ko7:125)

Yet, Kučerová goes on to argue that the destressing is only apparent. Rather it is the predicate rád 'glad' that is contrastively accented, leading to the destressing-like effect on its adjacent element. All in all, Kučerová argues that destressing (or non-stressing) for reasons of givenness does not exist in Czech.

'... but pensioners only sometimes punish dachshunds.'

An anonymous reviewer wonders how associates with jenom 'only' behave prosodically in Czech (and whether that affects the formal realization of the sentence under discussion). In the typical case, associates with jenom 'only' carry main sentence stress. In that respect, (ic), where někdy 'sometimes' carries the main sentence stress, is the typical realization. Yet, (ib) is felicitous even without někdy 'sometimes' carrying sentence stress. This sentence might just be an instance of jenom 'only' associating with a topic of sorts. Compare: Everybody was dancing, only John was still washing the dishes, where sentence stress need not fall on the associate of only, either.

19 This reordering is considered to be qualitatively different from " $G$-movement" in that it is strictly local (boiling down to "switching" the order of two neighboring words/constituents) and cannot be cyclic. See Ko7: Section 4.7 for discussion. 
Šimík \& Wierzba

\subsubsection{Technical implementation of the $G$-operator}

Let us look more closely at how the $G$-operator works and how it derives the given+presupposed-before-new generalization (18). Its semantics is defined recursively: it applies to a function, reducing its arity by one at every application, and stops when it applies to a proposition, see (27b); in this way the restriction to constituents of the propositional type in (18) is derived. At every non-vacuous application, see (27a), it returns a partial function, marking its argument as given+presupposed. Kučerová defines the semantics of $G$ in a syncategorematic way. That is, $G$ is not interpreted by the standard interpretation function $\llbracket . \rrbracket$, rather, whenever the computation encounters a node one of whose daughters is $G$, the rule in (27) is applied. In order to distinguish the metalanguage from the object language operator, we mark the former $\mathbf{G}$ and keep marking the latter as $G .^{20}$

(27) $\mathbf{G}(\llbracket B \rrbracket)=$
a. $\lambda x_{\alpha}: \kappa(x)$ is given+presupposed.G $(\llbracket B \rrbracket(x))$
(if $B$ is of type $\langle\alpha, \beta\rangle$ other than $\langle s, t\rangle$ ) or
b. $\llbracket B \rrbracket$
(if $B$ is of type $\langle s, t\rangle$ )
where $\kappa(x)$ is the constituent that denotes $x$. (adapted from K12:20)

The schematized trees below (nodes are labeled by denotations) might help the reader to grasp the functioning of this operator.

20 We are grateful to Paul Elbourne for making us aware of a number of technical problems with Kučerová's original technical solution. What you see is our attempt at an improvement. Besides some notational and technical issues, we depart from the original interpretation rule in the following respect. In her implementation, Kučerová assumes that givenness+presupposition is a property of denotations. This assumption is incompatible with the notion of givenness+presupposition introduced in Section 3.1.1 (and to be clear: also with Kučerová's original notion), where it is assumed to be a property of utterances (i.e., object language expressions). Since the latter assumption is unavoidable in the treatment of givenness - givenness cannot be reduced to a property of denotations, which are independent of discourse - we try to make Kučerová's implementation compatible with it. We introduce the operator $\kappa$, which maps denotations back to the constituents that gave rise to them. We further assume that a constituent can more or less be equated with the utterance of that constituent. 
The role of givenness, presupposition, and prosody in Czech word order

a. $B$ of type $\langle\alpha, \beta\rangle$ other than $\langle s, t\rangle$

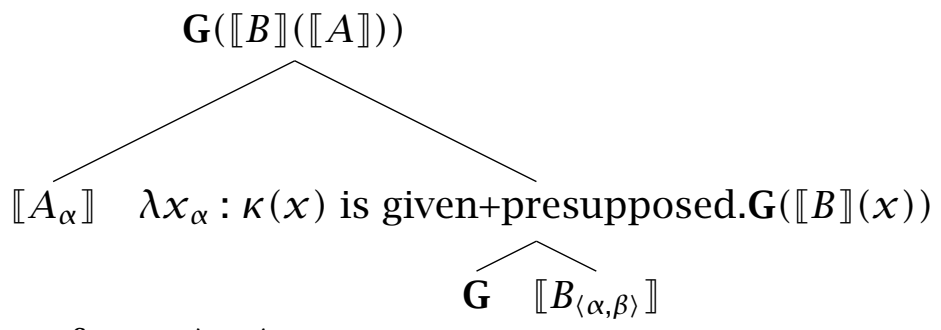

b. $B$ of type $\langle s, t\rangle$

$$
\overbrace{\mathbb{G} \quad B_{\langle\alpha, \beta\rangle} \rrbracket}
$$<smiles>CC(C)(Br)Br</smiles>

Let us now have a look at a particular example. In (29B) Marie and Pavlovi must be marked by $G$ as given+presupposed in order to comply with the Maximize Presupposition principle. Hence, they scramble to the propositional level in order to be located in the scope of the $G$-operator. ${ }^{21}$

(29) A: What do you know about Marie and Pavel?

B: Marie Pavlovi dala knihu. Marie.NOM Pavel.DAT gave book.ACC

'Marie gave Pavel a book.'

The LF of (29B) is in Figure 1. The $G$-operator is placed in between the given+ presupposed part Marie Pavlovi 'Marie to Pavel' and the new part dala knihu 'gave a book'. In this particular case, the complement of the $G$-operator denotes a two-place function, taking the two given expressions, one by one, as its arguments. This process is mediated by the $G$-operator. ${ }^{22}$

21 Alternatively, only Pavlovi scrambles and Marie stays in situ. We leave this option aside here because it is semantically indistinguishable.

22 The reader might wonder how the LF in Figure 1 is derived. Since Kučerová is not explicit about the details, we suggest how it could be done. (Note that our aim is not to defend Kučerová's theory; we just want to make it workable.) As is clear from the presence of lambda operators, Marie and Pavlovi appear in their scrambled positions. In order to derive the order of the scrambled constituents and the order of their respective lambdas, one must assume that Marie moves first (triggering immediate lambda insertion), after which Pavlovi moves and tucks in between Marie and its lambda (again followed by immediate lambda insertion). Finally, the $G$-operator is inserted in between the scrambled constituents and the lambdas. As pointed out by Paul Elbourne, such a scenario contradicts Kučerová's assumption that scrambling never involves tucking-in in Czech (Ko7:54-56). Nevertheless, it is the most viable one, as far as we can see. 


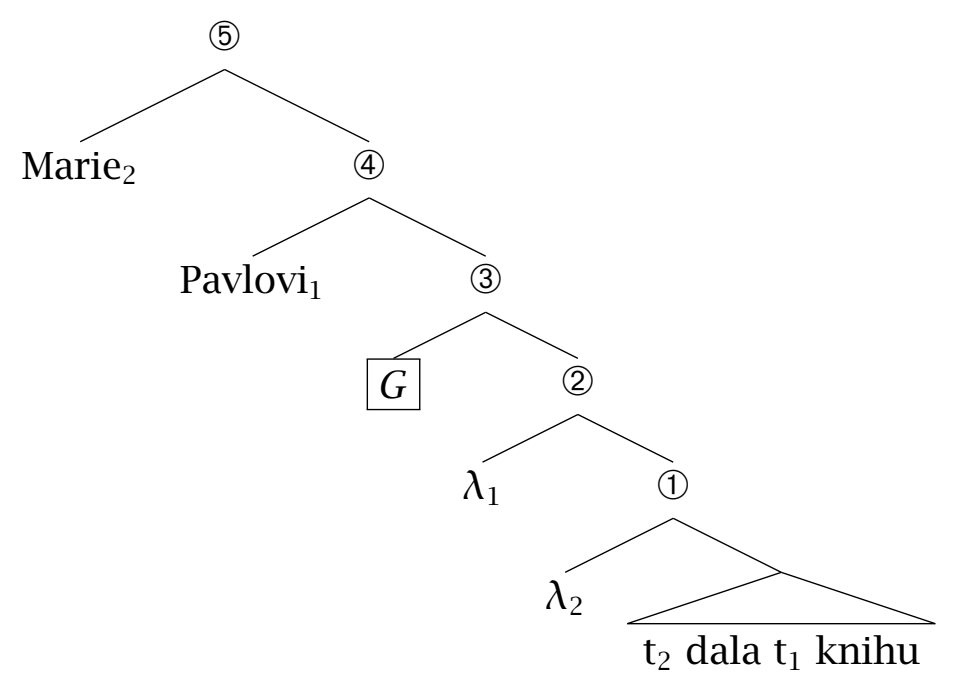

Figure 1 The LF of (29).

【(2)』= $\lambda x . \lambda y \cdot \lambda w \cdot y$ gave $x$ a book in $w$

$\llbracket(3) \rrbracket=\mathbf{G}(\lambda x \cdot \lambda y \cdot \lambda w \cdot y$ gave $x$ a book in $w)$

$=\lambda x: \kappa(x)$ is given+presupposed.

$(\lambda y . \lambda w . y$ gave $x$ a book in $w) \quad$ by (27a)

【4) $=[\lambda x: \kappa(x)$ is given+presupposed.

$\mathbf{G}(\lambda y . \lambda w . y$ gave $x$ a book in $w)]$ (Pavel) by FA

$=\mathbf{G}(\lambda y \cdot \lambda w \cdot y$ gave Pavel a book in $w) \quad$ by LR

$=\lambda y: \kappa(y)$ is given+presupposed.

$\mathbf{G}(\lambda w \cdot y$ gave Pavel a book in $w) \quad$ by (27a)

$\llbracket(5) \rrbracket=[\lambda y: \kappa(y)$ is given+presupposed.

$\mathbf{G}(\lambda w . y$ gave Pavel a book in $w)]$ (Marie) by FA

$=\mathbf{G}(\lambda w$.Marie gave Pavel a book in $w) \quad$ by LR

$=\lambda w$. Marie gave Pavel a book in $w \quad$ by (27b)

Figure 2 Derivation of truth conditions for the LF in Figure 1. 
The role of givenness, presupposition, and prosody in Czech word order

Figure 2 contains a compositional computation of Figure 1's truth-conditions. The denotation of (2) characterizes a relation between two individuals $x, y$ and a world $w$ such that $y$ gave $x$ a book in $w$. By applying the rule (27), we get the denotation of (3): a partial function that takes an individual as its argument and, if the constituent that the individual is a denotation of is given+presupposed, yields a function that one gets by applying $\mathbf{G}$ to the denotation of (1). Node (4) is computed by function application (FA), followed by lambda reduction (LR), and its denotation corresponds to the denotation of (1) (with variable corresponding to $t_{1}$ replaced by Pavel) selected by $G$. The denotation of (4) is only defined if the constituent Pavlovi is given+presupposed. After another application of (27), we get the denotation of (5): a partial function, applied to Marie, that takes an individual as its argument and, if the constituent that the individual is a denotation of is given+presupposed, yields the proposition that the individual gave Pavel a book such that the proposition is applied to G. By LR, we get the proposition that Marie gave Pavel a book such that the proposition is applied to $\mathbf{G}$. The final step in the derivation is a third application of $\mathbf{G}$; this time it applies to a proposition, an expression of type $\langle s, t\rangle$. By (27b), G functions as the identity function: it returns its argument as the value. In result, the LF maps to truth (relative to some $w$ ) iff Marie gave Pavel a book (in $w$ ). This meaning is only defined if the constituents Pavlovi and Marie are given+presupposed.

\subsubsection{Summary}

In this section we presented Kučerová's $(2007,2012)$ approach to word order alternations in Czech. We saw that her approach relates givenness+ presupposition directly to word order by making given+presupposed expressions structurally sensitive to a specialized operator at LF. This derives the given+presupposed-before-new generalization (18). If a base-generated order does not comply with the generalization, it can be "fixed" by scrambling given+presupposed expressions into the "given+presupposed area". Unmotivated scrambling is prohibited by a general economy condition. Finally, we saw that Kučerová suggests that there is no relation between givenness and prosody in Czech. In the upcoming section we discuss a competing hypothesis which crucially builds on such a relation. 
Šimík \& Wierzba

\subsection{A prosodic approach}

The idea that word order might not be affected by information structure directly but rather via prosody has been around for quite a while. The general shape of the argument is the following:

i. There are general rules for assigning main stress within a domain. One such rule is the nuclear stress rule of Chomsky \& Halle (1968), which requires the main stress in a sentence to be placed on the rightmost accented constituent.

ii. Information structure relates to prosody. It has been argued, for instance, that focused expressions must contain main stress (Chomsky 1971, Jackendoff 1972 and many others since then) and that given expressions (modulo focus, see footnote 5) cannot do so (Halliday 1967, Ladd 1980, Taglicht 1982, among others).

iii. To the extent that word order is free, constituents can be reordered in a way that satisfies both the general prosodic rules and the information structure-prosody relations.

Many linguists proposed to account for information structure-driven word order alternations in this indirect way - for instance, Reinhart 1995, 2006, Zubizarreta 1998, Neeleman \& Reinhart 1998, Büring 2001, Büring \& GutiérrezBravo 2001, Szendrői 2001, 2003, Arregi 2002, Arnaudova 2003, SamekLodovici 2005, Hamlaoui 2009 and Hamlaoui 2011. Languages for which these analyses were devised include German, Dutch, Spanish, Hungarian, Italian, French, and Bulgarian. To the best of our knowledge, Czech has never been explicitly analyzed in this way. (The analysis is briefly considered and rejected in Ko7: Section 4.7.)

Building on previous work, we sketch a simple prosodic analysis and show how it can account for the basic word order alternation patterns in Czech.

\subsubsection{Basics of Czech sentence prosody}

According to Daneš (1957), "[t]he basic rule is: the intonational center of phonological phrases as well as the intonational center of the utterance is always placed on the last word of the phrase and the last phrase of the utter- 
The role of givenness, presupposition, and prosody in Czech word order

ance, respectively." (p. 63) ${ }^{23}$ This roughly means that within a phonological phrase it is the last phonological word that is most prominent and within an utterance (or, an intonation phrase) it is the last phonological phrase that is most prominent. ${ }^{24}$ Consider the example in (30). The utterance is divided into three phonological phrases each of which contains two prosodic words. (Short prepositions do not count as prosodic words in Czech.) It is always the rightmost prosodic word of each phrase that receives the phrasal stress. Out of these phrasal accents it is the rightmost one which realizes the main stress of the utterance. (Just for this particular case, we mark phrasal stress by boldface and sentence stress by boldface+capitals. Note that otherwise, boldface alone stands for sentence stress. $)^{25}$

(30) (Všecky traktory) (rychle vyjely) (do družstevních POLÍ). all tractors.NOM quickly went.out into cooperative fields.GEN 'All tractors quickly went out into the cooperative fields.' adapted from Daneš 1957

Following most literature, we will assume that the assignment of sentence stress is regulated by some version of the nuclear stress rule of Chomsky \& Halle 1968. For concreteness, we adopt the NSR-I of Truckenbrodt 1995 and his subsequent work:

(31) NSR-I: Strengthen the rightmost phrasal stress in the intonation phrase. (Truckenbrodt 2012)

In the next subsection we move to the second main ingredient of the analysis.

\subsubsection{Stress and givenness}

The reader might already have noticed that RŠ does not share Kučerová's intuition that there is no "deaccenting" of given expressions in Czech (footnotes 13,15 , and 18). In fact, the intuition that given expressions avoid stress in Czech is not new. Already Petřík (1938: 132-133) says that "[c]onstituents which are known, repeated, self-evident, or functional, are typically unac-

23 Translation of: "Základní pravidlo zní: intonační centra úseková i intonační centrum výpovědní je umístěno vždy na poledním přízvukovém taktu úseku a výpovědi."

24 Prominence is realized by a combination of pitch and intensity, according to Daneš (1957). 25 We abstract away from the problem of syntax-prosody mapping. While Daneš (1957) admits that syntax and semantics play a rather important role in phonological phrasing in Czech, the relation is quite complex and not substantial for the present purposes. 
cented, whereas constituents which are important, new (i.e., not repeated) have accent, in which they can be told apart from known constituents." (cited from Daneš 1957: 62; italics ours) ${ }^{26}$ Based on these intuitions, we hypothesize that there is indeed a relation between stress and givenness in Czech, which we formulate by the following constraint (inspired by Féry \& Samek-Lodovici's (2006) DESTRESS-GIVEN). ${ }^{27}$

*STRESS-GIVEN: A given expression does not realize sentence stress.

Note that we formulate the constraint for given rather than given+presupposed expressions. We take it to be the null hypothesis that Czech does not differ from other languages in its deaccenting in this respect, which is, moreover, supported by the intuition of RŠ (see footnotes 13 and 18).

\subsubsection{Deriving scrambling from NSR-I and *STRESS-GIVEN}

If syntax generates a string in which the final position is occupied by a given expression, either NSR-I or *STRESS-GIVEN is violated. Let us have a look at a particular example. In (33), the expression knížku 'book' is given according to our definition of givenness from Section 2.2. Since Czech is SVO (and prodrop), the syntax places it at the end of the sentence by default. Prosody then has a choice: either it satisfies NSR-I by strengthening the rightmost phrasal stress, as in (33a), or it satisfies *STRESS-GIVEN by realizing sentence stress elsewhere than on knížku, as in (33b). In the former case *STRESS-GIVEN is violated and in the latter case NSR-I is violated. Neither sentence is therefore expected to be fully acceptable, which corresponds to the intuition of RS. ${ }^{28}$

26 Translation of: “Členy známé, prostě opakované, samozřejmé, nevýznamné, bývají bez přízvuku, kdežto členy důležité, nové (tedy neopakované) mívají důraz, jímž se právě odrážejí od členů známých.”

27 We call our constraint *STRESS-GIVEN rather than DESTRESS-GIVEN mainly because we do not subscribe to the idea that given material is literally "destressed" (i.e., that it first receives stress and then it "loses" it). As an anonymous reviewer correctly points out, there is also a difference in predictions because Féry and Samek-Lodovici's DeSTRESS-GIVEN denies prosodic prominence to any given expression, while our *STRESS-GIVEN only bans it from bearing sentence stress. One of the reasons why we use *STRESS-GIVEN is that we are not convinced that in pre-nuclear positions given expressions are denied prosodic prominence (at the phrasal level). However, the research that would support such a stand is yet to be done.

28 More particularly, (33a) is felt as less acceptable than (33b). Yet, we await the upcoming section for a more serious data discussion. 
The role of givenness, presupposition, and prosody in Czech word order

(33) Context: 'I haven't read any book for a long time.'

a. Zítra v knihovně si vypůjčím knížku. tomorrow in library.LOC REFL borrow.1SG $\overline{\text { book.ACC }}$ 'Tomorrow I'll borrow a book in the library.'

*STRESS-GIVEN violated

b. Zítra v knihovně si vypůjčím knížku. tomorrow in library.LOC REFL borrow.1SG book.ACC 'Tomorrow I'll borrow a book in the library.' $\quad$ NSR-I violated

It appears that syntax has not done a job good enough to satisfy the interface constraints. But it can do better, for instance if the VO order is switched to OV, as illustrated in (34). Placing main stress on vypůjčím 'borrow' in (34) satisfies NSR-I, as the verb is rightmost, and it also satisfies *STRESS-GIVEN, as the given expression knížku 'book' is devoid of sentence stress. ${ }^{29}$

(34) Context: 'I haven't read any book for a long time.'

Zítra v knihovně si knížku vypưjčím.

tomorrow in library.LOC REFL book.ACC borrow.1SG

'Tomorrow I'll borrow a book in the library.'

The prosodic analysis predicts that (34) is the optimal way of expressing the required truth-conditions in the context provided (which also corresponds to the intuition of RŠ).

The above illustration shows that scrambling can be forced (or at least preferred) in order to satisfy interface (prosodic and pragmatic) constraints. There is no need for a syntactic/LF device like Kučerová's $G$-operator in this account. The only thing that must be ensured is movement of the Akind which is free from the perspective of syntax (an assumption present in Kučerová's work, too). Alternatively, the "scrambled" order could be basegenerated, as in Fanselow 2001 among others. Nothing hinges on the choice, so we leave this issue open for future research.

\subsection{A multi-factorial approach}

It is of course possible that more than a single factor is responsible for word order alternations in Czech: a givenness-based word order restriction and a givenness-based prosodic restriction could both jointly contribute to the pref-

29 Note that this presupposes that transitive verbs carry phrasal stress in Czech. We believe this is indeed the case (at least by default). 
erence for noncanonical orders. Even though Kučerová's approach in its full strength is not compatible with the prosodic approach - Kučerová explicitly argues against the effect of givenness on prosody - a weaker version thereof might very well be. In order to be able to test and evaluate this possibility, we divide Kučerová's original approach into a number of independent claims.

i. G-operator: The G-operator introduces the requirement that every constituent in its scope be given+presupposed.

ii. Economy: Scrambling is only allowed if it produces new givenness+ presupposition marking.

iii. Givenness-prosody: Givenness is not marked prosodically.

Our experimental results reveal that assumptions 2 and 3 are too restrictive for Czech and should be abandoned. Assumption 2 is disqualified by the fact that scrambling takes place even if it is not motivated by givenness+presupposition marking; that is, given indefinites also scramble, and not just given definites. Assumption 3 is disqualified by the interaction between givenness and sentence stress that we find. At the same time, however, we will see that the prosodic approach alone cannot explain the observed interaction between word order and definiteness - something that assumption 1 seems to be suitable for. We will argue that a weaker version of assumption 1 is in fact needed: a constraint that says that non-presupposed expressions should not precede presupposed ones. We thus arrive at the following multi-factorial picture: givenness interacts directly with prosody (via *STRESSGIVEN) and only indirectly with word order (via NSR-I) and presupposition interacts directly with word order - via a newly proposed interface constraint *NON-PRES>PRES, which reduces the acceptability of sentences in which non-presupposed expressions precede presupposed ones.

\section{Experiments}

We designed and ran two experiments on scrambling in Czech. Both experiments, together with materials from an unrelated study serving as fillers, were combined to one experimental set-up, so the information about participants and method is shared by all of them and will be only described once. A description of the design and materials and a discussion of the predictions and results will be presented and discussed for each of the two main 
The role of givenness, presupposition, and prosody in Czech word order

experiments separately in the following sections. After that, we will present a number of additional post-hoc analyses, in which we investigate potential confounds. This section includes a discussion of an auxiliary experiment that complemented experiment 1.

\subsection{Experiment 1: The impact of definiteness on scrambling}

In this experiment, we used structures in which a discourse-new verb was either preceded or followed by an object that was given (i.e., that was mentioned in the preceding context). We manipulated the relative order of verb and object, the position of sentence stress, and the definiteness of the object.

\section{Participants and method}

41 native speakers of Czech took part in the experiment. All of them were university students at Olomouc (10 participants) or Prague (31). They were paid for participation. ${ }^{30}$

Auditory stimuli were used, because one of the manipulated factors was accentuation. They were presented via headphones. Each stimulus was a short dialog, where the question/context was read by a woman and the response by a man. At the beginning of the experimental trial, the participants read the experiment instructions on the computer screen telling them to rate the acceptability of the response in each dialog. A translation of the instructions can be found in Appendix A. Before the trial started, the task was illustrated by three examples. Then a total of 126 stimuli were presented (6 training items at the beginning, 40 items from experiment 1, 20 from the auxiliary experiment, 20 from experiment 2, 40 from two unrelated experiments) in pseudo-randomized order. When the audio file with a stimulus stopped, participants rated the response on a 1-9 scale (1 completely unacceptable, 9 completely acceptable) using the computer keyboard. Reaction times were measured. After the rating, they could decide when the next file was played by pressing space. The experiment took 20 to 40 minutes, depending on the individual pace of participants.

30 We ran a pilot experiment with 20 participants in Brno. 
Šimík \& Wierzba

\section{Design and Materials}

We used a $2 \times 2 \times 2$ within-items design. The three factors we manipulated were WORD ORDER (verb $\gg$ object vs. object $\gg$ verb), STRESS (sentence stress on the verb vs. on the object) and DEFINITENESS (definite vs. indefinite object NP).

We constructed 40 item sets, each consisting of 8 items that only differed in the specification of the manipulated factors, resulting in 320 items in total. Each item was a short dialog - that is, a context of one to maximally three short sentences followed by a response, which contained the target structure. The last two elements of the target clause always were a transitive verb and a bare noun phrase as its direct object. The verb was discourse-new. All target sentences were episodic (i.e., not generic; recall that generic plurals are the only case of non-presupposed NPs that can scramble under certain circumstances according to Kučerová, as discussed in Section 3.1.4).

The factor WORD ORDER determined whether the object followed or preceded the verb. STRESS determined whether sentence stress fell on the verb or on the object; this entailed the distinction between stress on the rightmost element of the sentence (the default case), or a deviation from the default stress pattern (stress shift), depending on the specification of WORD ORDER. The native speaker who read the target sentences for us was instructed how to produce the different stress patterns in advance and was supervised during the recording. Elements marked as bearing sentence stress in the items bore the nuclear pitch accent. If anything followed them, it was deaccented. Preceding elements optionally bore prenuclear (phrasal) accents. DEFINITENESS was manipulated by constructing two different contexts for each item. In both contexts the relevant NP that reoccurred in the response was given (the NP was mentioned in the context), but in the "definite" context the existence of a unique referent of this NP was established, which triggered a definite interpretation of the NP in the target sentence; in the "indefinite" context, no such referent was introduced, thus encouraging an indefinite interpretation of the target NP. The expression "definite/indefinite context" serves as a shorter way of saying "context which does/does not support the presupposition of a definite NP in the target sentence". We take it that the object NP was presupposed in Kučerová's sense in definite contexts, and non-presupposed in indefinite contexts. The verb was non-presupposed and discourse-new. ${ }^{31}$ The object and the verb were always contained within

31 We assume that a verb like see counts as presupposed if $\exists x . \exists y \cdot \operatorname{see}(x, y)$ is presupposed. 
The role of givenness, presupposition, and prosody in Czech word order

one clause and consequently also within a propositional domain, which is assumed to be the relevant domain for the given+presupposed-new partition in Kučerová's account. Note that in the discussion of the predictions and the results we will ignore all preverbal elements. These included complementizers, auxiliaries, pronouns, and adverbials. We assume that these either cannot be given/new in a nontrivial way, or (in the case of pronouns) would fall into the category of lexically given+presupposed elements that do not require to be marked by the $G$-operator according to K12:26. For the predictions of the prosodic approach, the presence of these elements does not play any role.

The following token set in (35) and (36) exemplifies all eight conditions. Since contexts and responses were recorded separately, we were able to make sure that the phonetic realization of the target sentences was identical in the definite and indefinite condition and was not influenced by the context. More particularly, the same recording was used for (35a) and (36a), (35b) and (36b), and so on. In all following examples, given elements are marked by underlining, given+presupposed elements are marked by double underlining, and sentence stress is marked by boldface.

(35) Definite context: 'I don't know how long we will tolerate this. We have to get rid of that rat in the cellar.'
a. No, volal mi Jirka, že prý právě potkana well called me.DAT Jirka.NOM that allegedly just rat.ACC objevil.
found
'Well, Jirka called and said that he has just found the rat.' $\underline{\underline{O}} \mathbf{V}$
b. No, volal mi Jirka, že prý právě objevil potkana. $\quad$ V $\underline{\underline{O}}$
c. No, volal mi Jirka, že prý právě objevil potkana. $\quad$ V
d. No, volal mi Jirka, že prý právě potkana objevil. $\quad \underline{\underline{\mathbf{O} V}}$

(36) Indefinite context: 'I don't know what you are talking about. There have never been rats in our cellar.'
a. No, volal mi Jirka, že prý právě potkana
well called me.DAT Jirka.Nom that allegedly just objevil.
found
'Well, Jirka called and said that he has just found a rat.' $\quad \underline{\mathrm{OV}}$
b. No, volal mi Jirka, že prý právě objevil potkana. $\quad \overline{\mathbf{V}} \underline{O}$
c. No, volal mi Jirka, že prý právě objevil potkana.
d. No, volal mi Jirka, že prý právě potkana objevil. 
The resulting 320 items were distributed on eight lists using a LatinSquare design, so that every participant heard exactly one token of each of the 40 sets, and each condition the same number of times (five times). Each list was randomized separately. All experimental items are listed in Appendix B with glosses and translations.

\section{Predictions}

The system developed in Kučerová 2007, 2012 predicts that given+presupposed objects like the ones in (35) should behave differently from given but not presupposed objects like the ones in (36): a given+presupposed object should obligatorily scramble over the discourse-new verb, whereas a given but non-presupposed one should obligatorily stay in situ and receive main sentence stress. This pattern follows from the interplay of several components of the system: the $G$-operator, the economy condition, and the restrictions on stress shift in Czech. In what follows, we will explain in detail how these components contribute to the predicted pattern. A summary of the components and the predictions following from them is provided in Table 1.

The central component is the $G$-operator. As described in the previous sections, it has to be inserted in such a way that all given+presupposed elements precede it and all other elements follow it. Thus, any structure with a non-presupposed element preceding a given+presupposed one should be problematic. With respect to our items this means that VO word order should be impossible in the conditions with an object that is interpreted as definite. In these cases, the object is given+presupposed and should precede the discourse-new verb, otherwise the $G$-operator cannot be inserted without leading to presupposition failure or violating Maximize Presupposition. In contrast, no problem arises in the conditions with an indefinite object. Here, the object is non-presupposed and therefore does not have to precede the verb. So, only taking into account the assumptions about the $G$-operator for now, VO word order with a definite object is predicted to be unacceptable, whereas all other conditions should be unproblematic. In more technical terms, this means that an interaction between word order and definiteness is predicted: changing the word order from VO to OV has a different effect on conditions with a definite object (which it makes better) than on conditions with an indefinite object (on which it has no effect). How this kind of interaction would be reflected in our experimental design is illustrated in the topmost graph in Table 1. 
The role of givenness, presupposition, and prosody in Czech word order

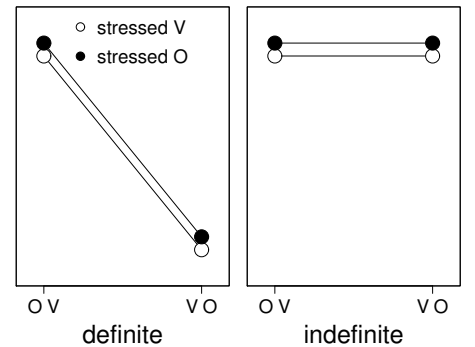

Claim: The $G$-operator requires all given+ presupposed elements to precede all others.

This predicts an interaction between word order and definiteness: scrambling should be obligatory for definite objects and optional for indefinite ones.

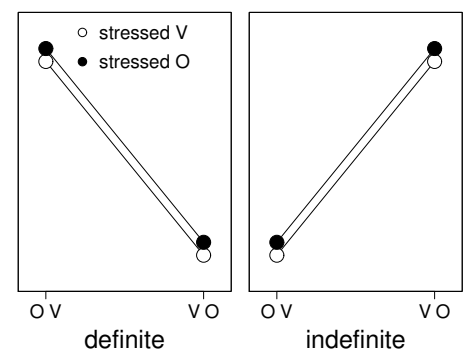

Additional claim: The economy principle bans unmotivated movement.

This predicts an interaction between word order and definiteness: scrambling should be obligatory for definite objects and banned for indefinite ones.

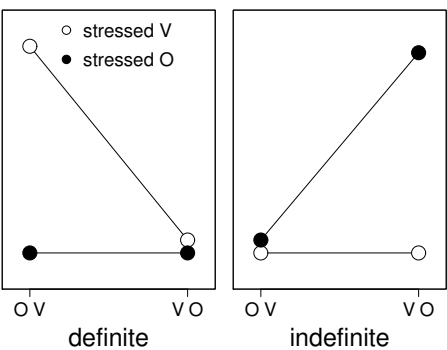

Additional claim: Stress shift is very restricted in Czech and not licensed by mere givenness.

This predicts an interaction between word order, stress and definiteness: the conditions with shifted stress should be banned.

Table 1 Predictions derived from the components of the system developed in Kučerová 2007, 2012 
The second component of Kučerová's system that is relevant for deriving the predictions with respect to our experiment is the economy principle, which is assumed to restrict Czech scrambling. Syntactic movement is only allowed if it helps to arrive at an otherwise unavailable interpretation, which in this context means that scrambling should only be possible if it allows an otherwise unavailable correct insertion of the $G$-operator. Unmotivated scrambling (i.e., scrambling that does not help to achieve a partition between given+presupposed and other elements) should be banned. For the items in this experiment this means that an indefinite (non-presupposed) object should not be able to scramble over a non-presupposed verb. If we take this into account in addition to the assumptions about the $G$-operator, the predictions for items with a definite object stay the same, but the predictions for the indefinite conditions change: scrambling should be banned for them. This still predicts an interaction between word order and definiteness, but with a different pattern. Changing the word order from VO to OV improves items with a definite object, and degrades items with an indefinite object. This pattern is illustrated in the middle graph in Table 1.

The third component is the assumption that stress shift only happens under very restricted conditions in Czech, namely when a generic plural is adjacent to a contrastive verb, as described in Section 3.1.4. No contrastive alternative to the verb was present in our items, so stress shift is predicted to be unmotivated and should lead to a decrease in acceptability (but see Section 5.5 for a discussion of potential contrast accommodation). When we take this into consideration in addition to the assumptions about the $G$-operator and the economy condition, an interaction between all three factors definiteness, word order, and stress is predicted. This is illustrated in the third graph in Table 1. This pattern expresses a three-way interaction, because the two conditions that are predicted to behave differently from all others (OV order with a definite object and stress on the verb and VO order with an indefinite object and stress on the object) differ in their specification of all three factors. This means that the prediction cannot be formulated without referring to all factors.

The predictions of the prosodic approach that we sketched in Section 3.2 follow from the interplay of two constraints: the NSR-I, which requires sentence stress to fall on the rightmost element, and *STRESS-GIVEN, which prohibits given elements from bearing sentence stress. Under the assumption that violating one constraint is worse than violating no constraint, but better 
The role of givenness, presupposition, and prosody in Czech word order

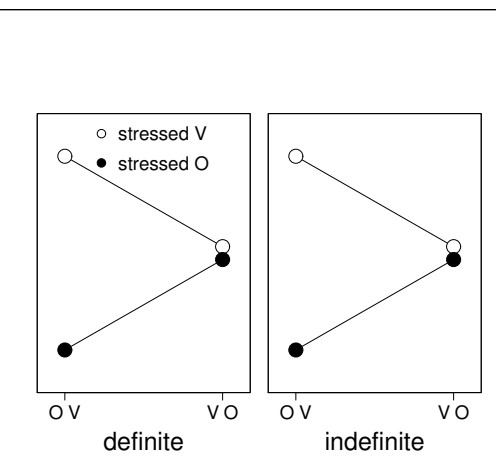

Claim: NSR-I and *STRESS-GIVEN are the relevant constraints for word order variation in Czech, and constraint violation is cumulative.

This predicts an interaction between word order and stress: in OV order stress on $\mathrm{O}$ causes two constraint violations, in $\mathrm{VO}$ order one constraint is violated no matter where sentence stress falls.

Table 2 Predictions of the prosodic approach

than violating two constraints, the following predictions emerge. OV order with sentence stress on the verb should be the best condition, because none of the constraints is violated. OV order with sentence stress shifted to the object should be the worst condition, because both constraints are violated: a given element is accented, and sentence stress does not fall on the rightmost element. VO order with sentence stress on the verb and VO order with sentence stress on the object should both have an intermediate status in comparison to the other conditions, because one of the constraints is violated in each of them. This can be described as an interaction between stress and word order: where sentence stress falls should have a greater effect on items with OV order than on items with VO order. The prosodic approach makes no predictions about the definiteness factor. This pattern is illustrated in Table 2.

\section{Results}

We used a cumulative link model with random intercepts for subjects and items to estimate the effects of our manipulations (using R, R Core Team 2013, and the package ordinal, Christensen 2013). Predictors were centered. One of the items (number 29 in the list provided in Appendix B.3) was excluded from analysis because we noticed that it had been constructed incorrectly. (Both contexts supported a definite reading.) For all three factors, ORDER, STRESS and DEFINITENESS, a significant main effect was found: Overall, OV order was rated significantly higher than VO $(z=4.94, p<0.001)$, stress on $\mathrm{V}$ was rated significantly higher than stress on $\mathrm{O}(z=21.32, p<0.001)$, 
and sentences with indefinite objects were rated significantly higher than sentences with definite objects $(z=5.21, p<0.005)$. Significant interaction effects were found for ORDER and STRESS $(z=10.63, p<0.001)$, and for ORDER and DEFINITENESS $(z=4.57, p<0.001)$. No significant interaction was found between STRESS and DEFINITENESS $(z=0.11, p=0.91)$ nor between ORDER, STRESS, and DEFINITENESS ( $z=0.08, p=0.94)$.

Medians (as well as interquartile ranges) are summarized in Table 3 and illustrated graphically in Figure 3.
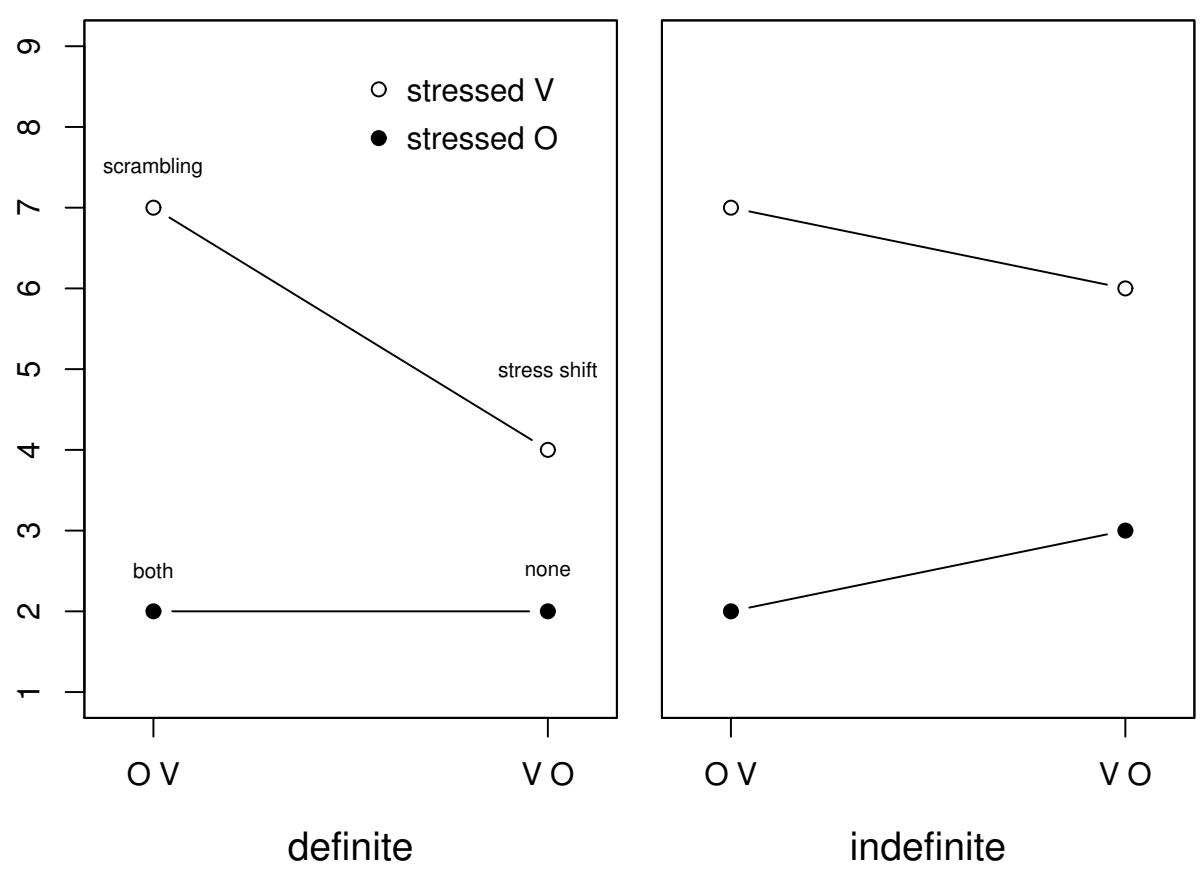

Figure 3 Plot of medians for experiment 1

\section{Discussion of the results}

The results show that the predictions following from the complete system presented in Kučerová 2007, 2012 were not borne out. No three-way interaction between the three factors was found. When we compare the results to the predicted pattern (the third graph in Table 1), we can see that the results for definite objects indeed resemble the predicted pattern in that the scrambled structure with stress on the verb is the best of the four conditions. 
The role of givenness, presupposition, and prosody in Czech word order

\begin{tabular}{llllrr}
\hline order/stress & definiteness & example & description & median & IQR \\
\hline$\underline{\underline{\mathrm{OV}}}$ & definite & $(35 \mathrm{a})$ & scrambling & $\mathbf{7}$ & $(4)$ \\
$\underline{\mathbf{V}}$ & definite & $(35 \mathrm{~b})$ & stress shift & $\mathbf{4}$ & $(4)$ \\
$\underline{\underline{\mathrm{OV}}}$ & definite & $(35 \mathrm{~d})$ & both & $\mathbf{2}$ & $(3)$ \\
$\underline{\underline{\mathrm{O}}}$ & definite & $(35 \mathrm{c})$ & none & $\mathbf{2}$ & $(3)$ \\
\hline$\underline{\mathrm{OV}}$ & indefinite & $(36 \mathrm{a})$ & scrambling & $\mathbf{7}$ & $(3)$ \\
$\overline{\mathbf{V}}$ & indefinite & $(36 \mathrm{~b})$ & stress shift & $\mathbf{6}$ & $(4)$ \\
$\underline{\mathrm{OV}}$ & indefinite & $(36 \mathrm{~d})$ & both & $\mathbf{2}$ & $(3)$ \\
$\underline{\mathrm{V}}$ & indefinite & $(36 \mathrm{c})$ & none & $\mathbf{3}$ & $(4)$
\end{tabular}

Table 3 Summary of medians and interquartile ranges (IQR) for experiment 1

However, the results for indefinite objects differ severely from the predicted pattern. It is clearly not the case that VO order with stress on the object is the only acceptable order there.

Let us evaluate the components of Kučerová's system separately. At first sight, the results provide evidence against the assumption that givenness cannot license stress shift. Whereas shifting the stress to the object in OV word order is unacceptable (which is expected, since there is no motivation for it), stress shift away from the given object raises the acceptability in VO word order significantly $(z=5.78, p<0.001$ in the definite condition and $z=5.12, p<0.001$ in the indefinite condition). ${ }^{32}$ Note, however, that we will qualify this finding in Section 5.5, where we report additional post-hoc analyses: it is possible that the acceptability raising effect of stress shift can be reduced to the confounding factor of contrast accommodation.

The predictions that follow from the economy principle were not borne out: indefinite given objects can be scrambled over the verb equally well as definite given objects, and scrambling is better than leaving them in situ, just like it is the case for definite given objects. Pairwise comparisons show that the scrambled condition with stress on the verb is better than the other three conditions both for definite and indefinite objects (all $z \mathrm{~s}>5$, all $p \mathrm{~s}<0.001$ ). If the economy principle held, scrambling should be banned for non-presupposed elements, because it is not necessary for a successful insertion of the

32 We used Mann-Whitney-U-tests for post-hoc pairwise comparisons and for these tests we report p-values after Holm-Bonferroni correction, treating all pairwise comparisons within the data of experiment 1 as a family of tests. 
$G$-operator. (None of the elements is presupposed, so none has to be marked by the operator.)

The results do provide some support for the predictions following from the mechanism of the $G$-operator. A significant interaction between word order and definiteness was found, and it goes in the predicted direction: the acceptability difference between OV and VO order is less pronounced for indefinite than for definite objects. Pairwise comparisons show that VO order is significantly better for indefinite objects than for definite objects, for both stress patterns $(z=4.36, p$ s $<0.001$ for stress on $V ; z=4.12$, $p$ s $<0.001$ for stress on $\mathrm{O}$ ). The data points for OV with stress on the object deviate from the predicted pattern (the topmost graph in Table 1), but this could be attributed to an independent constraint. Yet, it has to be noted that an obligatory partition between given+presupposed elements, as predicted by the $G$-operator, is not the only generalization compatible with the observed pattern. It would, for instance, also be compatible with the idea that presupposed elements have a stronger tendency to scramble, or that presupposed elements following non-presupposed ones are problematic. Note that these generalizations would only make reference to presupposition, not to givenness. The data obtained from experiment 1 cannot decide between these options; this question will be addressed again in the discussion of experiment 2, which sheds more light on it.

As for the prosodic approach, the prediction that word order should interact with stress was borne out. However, the results only fully resemble the predicted pattern for the items with an indefinite object. For this group, it is indeed the case that OV order with stress on the verb (which does not violate NSR-I nor *STRESS-GIVEN) was better than items with VO order (violating one constraint each; $z=5352, p<0.001$ for scrambling vs. VO with stress shift, $z=9.27, p<0.001$ for scrambling vs. VO without stress shift), which in turn were more acceptable than OV with unmotivated stress shift (violating both constraints; $z=9.27 / z=4.27$, both $p$ s $<0.001$ ). For the group of items with definite objects, too, OV order with stress on the verb is significantly better than the conditions with VO order $(z=8.61$ $/ z=12.23$, both $p$ s $<0.001$ ), and stress shift in turn is better than OV with stress on the object $(z=6.31, p<0.001)$. However, equal acceptability was found for OV and VO with a stressed object ( $z=0.77, p=1)$, which is unexpected, as they differ in the number of violated constraints. Furthermore, the prosodic approach cannot account for the interaction between word order and definiteness that was observed. 
The role of givenness, presupposition, and prosody in Czech word order

\subsection{Experiment 2: A given element in nonfinal position}

In this experiment, we only tested structures in which a given object was in its in situ position. The items differed from those of experiment 1 in that the object was followed by a prepositional phrase, which received the sentence stress.

\section{Design and Materials}

In this experiment, we used a $2 \times 2$ between-items design. The manipulated factors were DEFINITENESS OF THE OBJECT NP and and GIVENNESS OF THE PP.

We constructed 20 items. Each participant was exposed to all of the items. All items involved a discourse-new transitive verb and a given object, which always followed the verb, and a PP in the sentence-final position. The PP was always accented; in half of the items it was new, in the other half it was given.

Examples for all four conditions can be found below. (Again, given elements are marked by underlining, given+presupposed element are marked by double underlining, and sentence stress is marked by boldface.)

(37) New PP, definite object NP. Context: 'I've just come back from the carwash. The car is washed now.'

Měli byste ještě zavézt auto do garáže.

should subj.2PL still take car.ACC to garage.LOC

'You should still take the car to the garage.'

(38) Given PP, definite object NP. Context: 'What are the bags doing in the corridor? I couldn't even go through.

Promiň, když jsem přšel z nákupu, nechal

sorry when AUX.PAST.1SG come from shopping.GEN let

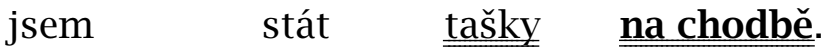

AUX.PAST.1SG stand.INF bags.ACC in corridor.LOC

'I'm sorry, when I was coming back from shopping, I forgot the bags in the corridor.'

(39) New PP, indefinite object NP. Context: 'I don't know how I should make the omelette - Roman forgot to buy eggs.'

Jsi si jistá, mám pocit, že jsem viděl

are.2SG REFL sure have.1SG feeling.ACC that AUX.PAST.1SG saw

vajíčko ve spíži.

$\overline{\text { egg.ACC }}$ in pantry.LOC

'Are you sure? I have the feeling that I saw an egg in the pantry.' 
Šimík \& Wierzba

(40) Given PP, indefinite object NP. Context: 'Yesterday they were presenting some wonderful pans in Tesco.'

Já jsem si nikdy nekoupil pánev $\underline{\underline{\mathbf{v} T e s k u}}$.

I.NOM AUX.PAST.1SG REFL never.NCI NEG.buy pan.ACC in Tesco.LOC

'I've never bought a pan in Tesco.'

\section{Predictions}

For establishing the predictions of Kučerová's theory, it is important to know whether the PP contains a definite or indefinite NP. Only elements that are both given and presupposed have to be marked by the $G$-operator, so both properties need to be known in order to determine whether they should occur inside or outside the operator's scope. Since we did not become aware of the relevance of definiteness within the PP until after the experiment (we are grateful to an anonymous reviewer for pointing this out to us), we did a post-hoc check of the PPs in all items, with the result that almost all PPs - both in the "new PP" and "given PP" conditions - were most likely to be interpreted as definite, as indicated in the examples in (40). There was only one exception among the "new PP" items with an NP that was more likely to be interpreted as indefinite. We excluded this item from the analysis for reasons of consistency. (This did not change anything in the significance or direction of the reported effects.)

The only condition in which the insertion of the $G$-operator would be

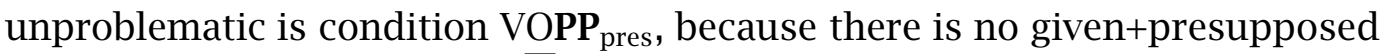
element. (The object is not presupposed, the PP is not given.) In all other conditions, there is a problem for the $G$-operator approach: in the conditions with a definite object, the object is given+presupposed, but follows a discourse-new verb; and in the condition with an indefinite object and a given PP, a given+presupposed NP (contained in the PP) follows a new verb and a non-presupposed object. Thus, condition VOPP $\mathbf{P}_{\text {pres }}$ should be better than all other conditions. This amounts to predicting an interaction between the two factors, since a difference between new PP and given PP is predicted for the group of items with an indefinite object, but not for the items with a definite object. The predicted pattern is illustrated in Table 4 .

According to the prosodic approach, the fact that a given object follows a new verb is unproblematic: it is only important that it is not in final position, so that it does not receive sentence stress under default stress assignment, and *STRESS-GIVEN is not violated. There should, however, be a problem with 
The role of givenness, presupposition, and prosody in Czech word order

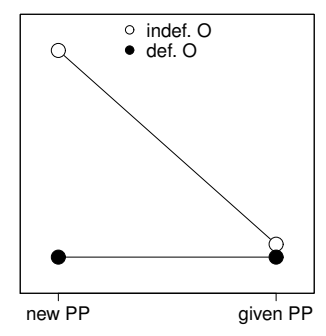

Claim: The $G$-operator requires all given+ presupposed elements to precede all others.

This predicts an interaction between givenness of the PP and definiteness of the object: a structure with an indefinite object and a discourse-new PP should be the only one allowing an unproblematic insertion of the $G$-operator

Table 4 Predictions derived from Kučerová 2007, 2012 for experiment 2

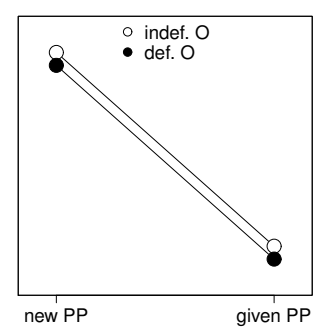

Claim: *STRESS-GIVEN is a relevant constraint.

This predicts a main effect of givenness of the PP: items with a given PP carrying sentence stress should be worse than with a new PP carrying sentence stress.

Table 5 Predictions of the prosodic approach for experiment 2

those conditions in which the sentence-final PP was given but stressed - these should be worse than those with a new PP. In other words, a main effect of the factor GIVENNESS OF THE PP is predicted. No predictions concerning the factor definiteness follow from this account. This pattern predicted by the prosodic approach is illustrated in Table 5.

\section{Results}

A cumulative link model with random intercepts for subjects and items revealed a significant main effect for GIVENNESS OF THE PP: conditions in which the sentence-final, accented PP was new were rated higher than those in which the PP was given $(z=5.22, p<0.001)$. The main effect of DEFINITENESS OF THE OBJECT was marginally significant: conditions in which the object was definite were rated higher than conditions in which it was indefinite $(z=1.91$, $p=0.056)$. There was no significant interaction $(z=0.06, p=0.95)$. 


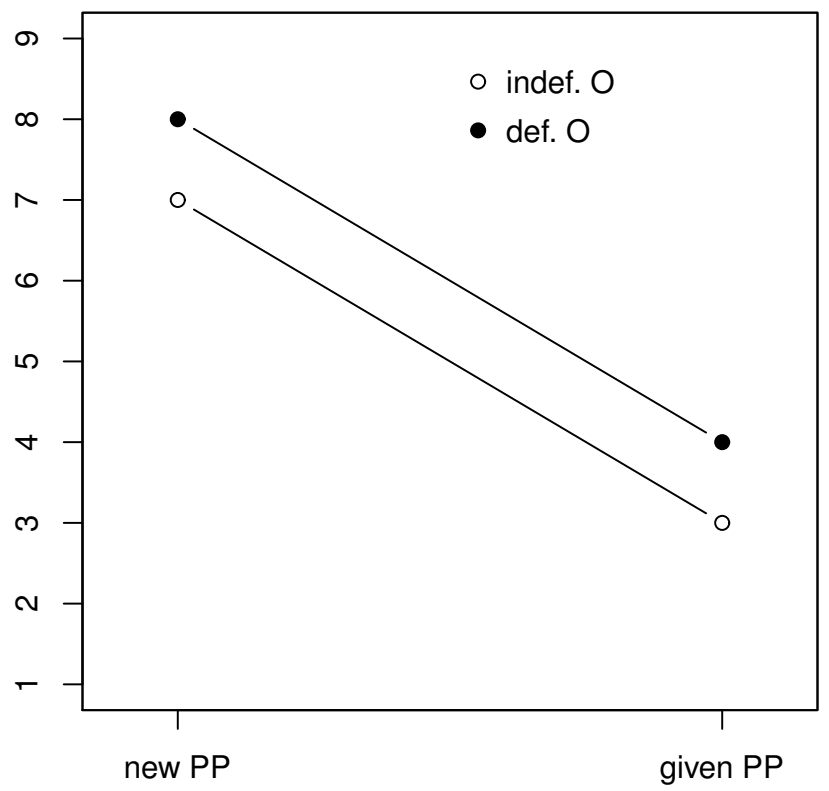

Figure 4 Plot of medians for experiment 2

\begin{tabular}{lllrr}
\hline definiteness & PP & example & median & IQR \\
\hline definite & new & $(39 \mathrm{a})$ & $\mathbf{8}$ & 3 \\
definite & given & $(39 \mathrm{~b})$ & $\mathbf{4}$ & 4 \\
indefinite & new & $(40 \mathrm{O})$ & $\mathbf{7}$ & 4 \\
indefinite & given & $(40 \mathrm{ob})$ & $\mathbf{3}$ & 3
\end{tabular}

Table 6 Summary of medians and interquartile ranges (IQR) for exp. 2

Pairwise Mann-Whitney-U-tests showed significant differences for all comparisons (all $z \mathrm{~s}>3$, all $p$-values $<0.001$ after Holm-Bonferroni correction).

\section{Discussion of the results}

The predictions of Kučerová's theory were not fully borne out. No significant interaction between the two manipulated factors was found. The only condition that would allow an unproblematic (vacuous) insertion of the $G$ operator (the one with a new verb, an indefinite object, and a new PP) is not the best-rated one: the same structure with a definite object was rated better. 
The role of givenness, presupposition, and prosody in Czech word order

As for the predictions of the prosodic approach, the prediction of a main effect of GIVENNESS OF THE PP was confirmed: it is better for a stressed PP to be new than given. However, again the observed effect of definiteness remains unexplained under the prosodic approach.

Although the results do not conform exactly to Kučerová's predictions, it is striking that a significant definiteness effect was found in both experiments. This suggests that the gist of Kučerová's theory - that there is a connection between word order and presupposition - is indeed reflected in the data. One way to explain the difference between definite and indefinite objects in experiment 2 would be to follow Kučerová in assuming that it is problematic for a non-presupposed NP to precede a presupposed one, which would correctly account for the acceptability penalty for indefinite objects preceding the presupposed PP. ${ }^{33}$ Note, however, that this explanation requires two deviations from Kučerová's theory. First, one would have to ignore the (nongiven, non-presupposed) verb in this structure, which means either that verbs do not play a role here (but then a completely different explanation would be needed to account for the differences found in experiment 1), or that the ordering preference should rather be conceptualized as something like a violable constraint rather than a partitioning requirement. Second, Kučerová's partitioning requirement concerns given+presupposed elements, which cannot exactly be the relevant property, because we see the same effect irrespective of the givenness status of the PP. Experiment 2 thus rules out one of the three possible generalizations that were all compatible with the results from experiment 1 : it is not the case that given+presupposed elements have to precede all other ones. It also rules out the idea that definite/presupposed elements have a stronger tendency to scramble, since we observe the effect even in a structure where nothing has moved. If the definiteness/presupposition effect was formulated with reference to movement operations, it would remain unexplained that it also shows up in the absence of movement. Thus, the correct generalization seems to be that it is problematic for presupposed elements to follow non-presupposed ones, no matter whether they are given, whether there is a partition, and whether syntactic movement has taken place.

33 We are grateful to one of the anonymous reviewers for suggesting this explanation. 
Šimík \& Wierzba

\section{Potential confounds}

A number of potential confounds in the two experiments have been brought to our attention. In this section, we want to address them by presenting additional comparisons and analyses within our data. For this, we annotated the items for several factors after running the experiment. This annotation can be found in appendix $C$. The strength of the conclusions that we can draw from these post-hoc analyses is limited, since they are not based on preplanned contrasts, and thus we do not have sufficient data for the relevant conditions in all cases. However, we believe that the trends that are visible in our data are nevertheless useful and can indicate which other factors might have indeed influenced the results and should be investigated more carefully in future studies.

\subsection{Accommodation of definiteness}

There is a potential counterargument to our conclusion that indefinite and definite given object NPs scramble equally well, having to do with the possibility of accommodation. Since we used bare NPs which are not specified formally for definiteness and manipulated this factor purely by context, maybe participants were able to accommodate a definite interpretation even in those contexts which were meant to force an indefinite interpretation. (This possibility was brought to our attention by Ivona Kučerová, p.c.)

It is not possible to rule this possibility out entirely based on our data, but we believe that if there is a way to explain the data without stipulating accommodation (and we think there is, by assuming that avoiding stress on given elements is the motivation for scrambling), this option should be preferred, as long as there is no positive evidence for accommodation.

One potential piece of evidence for accommodation would be to show that participants needed more time to rate the condition with scrambled indefinites than with scrambled definites. Some experimental studies have shown that presupposition accommodation takes time. Haviland \& Clark (1974), for instance, found that a target sentence like The beer was warm was read significantly faster in a context like We got some beer out of the trunk, which supports the presuppositions of the definite, than in a context like Andrew was especially fond of beer, which does not do so.

We found a pattern that could be interpreted along the same lines in a control sub-experiment for experiment 1 . We included this control experi- 
The role of givenness, presupposition, and prosody in Czech word order

ment to test whether our context manipulation worked in the intended way. As in experiment 1 , we constructed contexts that did/did not introduce a unique referent, but this time, we did not insert a bare noun phrase in the target sentence, but a (definite) pronoun. In contrast to bare nouns, definite pronouns always come with an existence presupposition, so it should be less acceptable to use one in a context where this presupposition is not fulfilled. Consequently, if our manipulation of this factor worked in the intended way, we would find a significant difference in acceptability between pronouns in the definite context and pronouns in the indefinite contexts. We did indeed find a significant difference for ratings (median of 9 for "definite" contexts, 6 for "indefinite" contexts; $z=15.61, p<0.001$ ), although the height of the median for indefinite contexts surprised us, considering that the existence presupposition of the pronoun was not fulfilled there. We also found a significant difference in reaction times $(2565 \mathrm{~ms}$ for "definite" contexts, 3918 for "indefinite" contexts; $t=6.61, p<0.001)$. A possible interpretation of these findings is that participants were (at least sometimes) accommodating the existence presupposition, resulting in longer reaction times.

Crucially, in experiment 1 there was no significant difference in reaction times between sentences containing an indefinite/definite object in OV word order, which are listed in Table $7^{34}$ (Welch's two-sample $t(390)=0.26, p=$ 0.80 for the comparison between definites and indefinites in the "scrambling" condition; $t(394)=0.93, p=0.35$ for the "stress shift" condition).

To sum up, Haviland and Clark-style accommodation effects were found in our auxiliary experiment with pronouns but did not show up in experiment 1. Hence, our data show no positive evidence for definiteness presupposition accommodation in the condition where indefinites scramble, even though the method was in principle suited for detecting such effects.

\subsection{Indefinite readings in definite contexts}

As we said in Section 2.1, bare NPs in Czech are ambiguous between definite and indefinite readings. In our experiment we used this property in order to build as direct a comparison as possible between definite and indefinite NPs. Since Czech has no articles, the use of any morphological marking always contributes more than just (in)definiteness.

34 Three data points were excluded because the reaction time was not recorded correctly due to a software error. 


\begin{tabular}{lllll}
\hline order/stress & definiteness & name & mean & SE \\
\hline$\underline{\underline{\mathrm{OV}}}$ & definite & scrambling & 3875 & 226 \\
$\underline{\underline{\mathrm{O}}}$ & definite & stress shift & 3601 & 192 \\
$\underline{\underline{\mathrm{OV}}}$ & definite & both & 3154 & 194 \\
$\underline{\underline{\mathrm{O}}}$ & definite & none & 3790 & 254 \\
\hline$\underline{\mathrm{OV}}$ & indefinite & scrambling & 3795 & 208 \\
$\underline{\mathbf{V O}}$ & indefinite & stress shift & 3846 & 180 \\
$\underline{\mathbf{O V}}$ & indefinite & both & 2922 & 200 \\
$\overline{\mathrm{V}} \underline{\underline{O}}$ & indefinite & none & 3407 & 197
\end{tabular}

Table 7 Summary of mean reaction times and standard errors for exp. 1

For this reason, we decided to manipulate indefiniteness contextually rather than morphosyntactically. That comes with a price though: we cannot be entirely sure that the participants interpreted the bare NPs as definite in definite contexts and indefinite in indefinite contexts - in principle, an undesired interpretation is possible in both cases. However, the two cases are of different nature: in order to obtain a definite reading in one of our "indefinite contexts", the existence of a salient unique referent would need to be accommodated (as discussed in the previous section), since no such referent is provided in the context. This would be parallel to using a definite article in the English translation of (41) in the "indefinite context" condition, which would only be felicitous if one imagines that a specific rat was mentioned in the previous context that is not explicitly presented.

In contrast, no accommodation is required to obtain an indefinite reading in a "definite context": although a particular rat was mentioned by the first speaker, the second speaker might not intend to refer to that rat. How plausible this reading is varies between the items, but it is in principle never semantically incompatible with the context, and it does not involve the need to accommodate previous context. Accordingly, an indefinite and definite article could both be felicitously used in the English translation of (41) in the "definite context" condition, as pointed out to us by Paul Elbourne. 
The role of givenness, presupposition, and prosody in Czech word order

(41) Definite context: 'I don't know how long we will tolerate this. We have to get rid of that rat in the cellar.'

Indefinite context: 'I don't know what you are talking about. There have never been rats in our cellar.'

No, volal mi Jirka, že prý právě (nějakého) potkana well called me Jirka.NOM that allegedly just some $\overline{\text { rat.ACC }}$ objevil.

found

a. 'Well, Jirka called and said that he has just found the rat.'

b. 'Well, Jirka called and said that he has just found a rat.'

In order to find out whether this potential ambiguity in the materials foiled the definiteness manipulation and influenced our results, we ran a post-hoc control study (as proposed by an anonymous reviewer; we are grateful for this suggestion). We used a forced choice test: we presented the items that were used in experiment 1 in written form with a gap preceding the critical bare NP, and participants had to choose a determiner that would fit best in this position. They could choose between a definite determiner (a demonstrative) and two indefinite ones (one used in negated sentences and the other one otherwise). An example, namely the test item from the control questionnaire corresponding to the definite condition of the experimental item (41), is given in (42):

(42) A: Nevím, jak dlouho to ještě budeme snášet. Musíme se toho potkana ve sklepě co nejdřív zbavit.

B: No, volal mi Jirka, že prý právě potkana objevil. toho (definite determiner) nějakého (indefinite determiner) žádného (negative concord indefinite determiner)

It is plausible to assume that the response frequencies in this task correlate with the distribution of definite/indefinite interpretations of bare NPs in experiment 1: although, as mentioned above, the overt determiners express more than just the definiteness/indefiniteness distinction, it is a central part of their meaning. However, we should also keep in mind that asking participants to choose between two explicitly listed readings is different from presenting ambiguous materials. 


\begin{tabular}{lrr}
\hline & "definite context" & "indefinite context" \\
\hline definite determiner & 291 & 33 \\
indefinite determiner & 99 & 305 \\
negative determiner & 26 & 65
\end{tabular}

Table 8 Response frequencies in the forced choice test

Clearly, we could not control for prosody in this test, but if Fodor's (2002) implicit prosody hypothesis is right, we can assume that the participants tended to read the items as involving default prosody and apply rightmost sentence stress. This makes the scrambled versions of our items better candidates for testing, as the OV condition was the most acceptable one in both the definite and the indefinite condition. The VO condition (or more precisely VO, assuming default stress), on the other hand, was less acceptable (especially in the definite condition), which could interfere with the interpretation and therefore give results that are not that informative.

We therefore tested our definite and indefinite context for each item from experiment 1 in the scrambled condition. 21 native speakers took part online via SoSci Survey (Leiner 2014). Each of them saw each item in either the definite or the indefinite condition. The results (again excluding the problematic item 29, which was not considered for the main analysis either) are summarized in Table $8 .{ }^{35}$

The contexts that were designed to invoke an indefinite interpretation of the object seem to have worked in the intended way: in 91.8\% of the cases, an indefinite determiner was chosen. Only one item, which is shown in (43), showed a clearly reversed preference (the definite determiner was picked nine times and an indefinite one only once). According to R ̌̌s's intuition, in this particular case the indefinite determiner indeed sounds infelicitous, although an indefinite interpretation is salient. It is thus possible that participants were interpreting the object in this item as indefinite in experiment 1 after all, but we cannot be sure about it. Removing this one item from the data set would, however, not change the significance of the comparisons nor any of the medians reported for the main experiment. For all other items, the indefinite determiner was chosen in the majority of cases (which we take

35 The unequal total sums for the two conditions result from a small mistake in the implementation of the questionnaire: one of the items was incidentally presented more often in the definite condition. 
The role of givenness, presupposition, and prosody in Czech word order

to mean at least $70 \%)$. We take this as a confirmation that the contextual triggering of indefinite interpretations was successful (which supports the reaction-time based argument against definiteness accommodation from the previous section).

(43) Indefinite context: 'So, how was the circus with the kids? Were there any clowns?'

Bohužel jsem nakonec nešel, ale vzpomínám unfortunately AUX.PAST.1SG in.the.end NEG.went but remember si, že se děti nemohly klauna dočkat. REFL that REFL kids.NOM NEG.could clown.GEN wait.INF 'Unfortunately, I didn't go in the end but I remember that the kids couldn't wait to see the/a clown.'

The picture is more mixed for the contexts that were intended to invoke a definite interpretation. In sum, the demonstrative determiner was selected in $70.0 \%$ of the cases. In 23 out of the 39 items, the definite determiner was chosen in the majority of the cases (again meaning at least 70\%); in 5 out of the 40 items, the indefinite determiner was chosen in the majority of the cases; finally, in 11 items, there was no preference for either the definite or the indefinite determiner. We call these three groups definite-preference group, indefinite-preference group, and no-preference group respectively. See appendix $\mathrm{C}$ for the lists.

Now, suppose our forced choice test is indicative of how the bare NPs were interpreted by the participants of experiment 1 . Then we would expect the items where the indefinite determiner was favored to pattern with the indefinite conditions, the items where the definite determiner was favored to pattern with the definite conditions, and the items where there was no preference to pattern somewhere in between. The results for the three groups of items are illustrated in Figure 5 and summarized in Table 9.

It can be seen in the plots that the indefinite-preference group (the leftmost plot in Figure 5) shows a different pattern than the definite-preference group (the rightmost plot in Figure 5): the difference between the two structures with stress on the verb $(\mathrm{OV}$ and $\mathrm{VO})$ is less pronounced in the former group (non-significant for the indefinite-preference group: $z=1.47, p=0.28$; significant for the definite-preference group: $z=7.10, p<0.001)^{36}$, whereas

36 Here we treated all possible comparisons within one of the groups as a family of tests for the purpose of significance level adjustment. 


\begin{tabular}{lrrr}
\hline order & indefinite-preference & no-preference & definite-preference \\
\hline OV & $\mathbf{6}(4)$ & $\mathbf{7}(4)$ & $\mathbf{8}(4)$ \\
VO & $\mathbf{4}(3)$ & $4(4)$ & $\mathbf{4}(4)$ \\
OV & $\mathbf{1}(1)$ & $2(2)$ & $2(4)$ \\
VO & $\mathbf{2}(2)$ & $3(3)$ & $\mathbf{2}(3)$
\end{tabular}

Table 9 Results for the items from experiment 1 with a definite context, grouped based on the results of the forced choice test; medians in boldface, IQR in parentheses
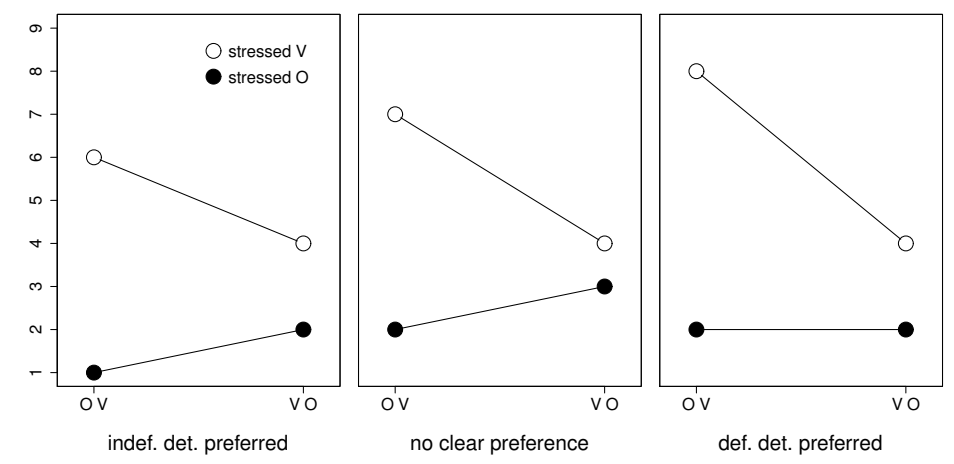

Figure 5 Medians for the items from experiment 1 with a definite context, grouped based on the results of the forced choice test

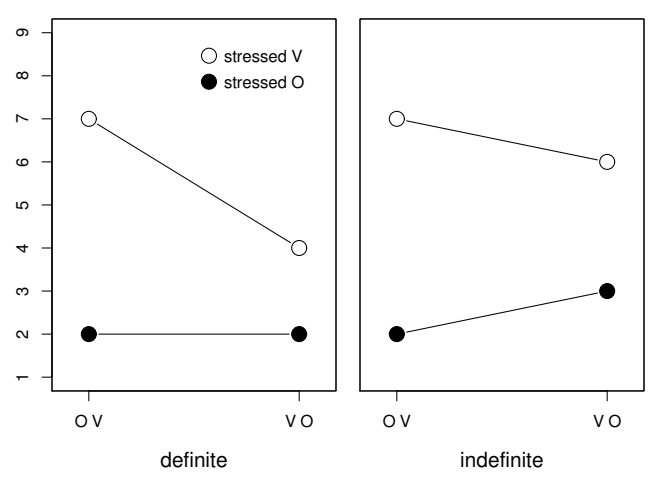

Figure 6 Overall results from experiment 1, repeated for comparison 
The role of givenness, presupposition, and prosody in Czech word order

the difference between the two structures with stress on the object (OV and VO) is increased (numerically; the difference is neither significant for the indefinite-preference group: $z=1.13, p=0.28$, nor for the definitepreference-group: $z=0.73$. $p=0.46$ ). This makes the pattern similar to the one that was found for the items involving an indefinite context, although the ratings were higher in absolute terms for these ${ }^{37}$ (presented again in Figure 6 for comparison). The no-preference group shows an intermediate pattern in that the difference between OV and VO is significant $(z=4.95, p<0.001)$ and greater than for the indefinite-preference group, but smaller than for the definite-preference group. (Like in the other two groups, the difference between $\mathrm{OV}$ and VO is non-significant here, too.) The difference between VO and VO is significant in all three groups (indefinite-preference group: $z=2.74$, $p=0.02$; no-preference group: $z=2.37, p=0.04$; definite-preference group: $z=4.59, p<0.001)$.

The observed trend, namely that the similarity to the indefinite items gradiently increases with a rising degree of preference for indefinite determiners, suggests that the results of the forced choice test indeed correlate with the interpretation preference in experiment 1 , meaning that participants might have obtained an indefinite interpretation in a part of our contexts that were supposed to trigger a definite interpretation.

Crucially, the general pattern reported for experiment 1 would change only minimally if the items which did not show a clear preference for the definite determiner (i.e., for which a definite determiner was chosen in less than $70 \%$ of the cases in the forced choice test) were removed from the item set in trials that were intended to provide a definite context, as the similarity of the rightmost plot in Figure 5 with the left plot in Figure 6 already indicates. The reported (in)significance of each factor and interaction in the cumulative link model would remain the same. The acceptability relations between the conditions would not change, either, as partly described above: all comparisons within the 'clean' subset of the items with a definite context show a significant difference (all $z \mathrm{~s}>3$, all $p \mathrm{~s}<0.001$ ), except for the difference between $\mathrm{OV}$ and VO $(z=0.73, p=0.46)$.

37 We speculate tentatively that the lower absolute acceptability of the indefinite-preference subset of the definite context items might be due to the fact that the indefinite reading was obtained in spite of the presence of a potential unique referent in the context, whereas the indefinite reading was more clearly supported in indefinite contexts. 
We conclude that this confound indeed affected a part of the items with a context that was supposed to trigger a definite interpretation, but it did not alter the results of experiment 1 significantly in general.

\subsection{Partitivity}

As pointed out by an anonymous reviewer, under Kučerová's theory, there is a group of indefinites that is predicted to behave like definites in that they require being marked by the $G$-operator, namely indefinites with a partitive interpretation. If a partitive reading was available for the indefinite object in our items, this could explain our finding that indefinite objects scramble equally well as definite ones, which is otherwise unexpected under Kučerová's theory. For that reason, we conducted a post-hoc analysis of the items and divided them into three groups (based on the intuitions of RŠ):

i. items in which a partitive interpretation was possible (11 items),

ii. unclear items, meaning that the test that we applied had inconclusive results ( 7 items), and

iii. items in which a partitive interpretation was not possible (21 items).

In what follows, we will describe our criteria for the categorization based on two examples.

(44) combined with $(44 \mathrm{a})$ represents the type of item where a partitive interpretation of the indefinite is very unlikely. While it is possible and in fact very natural to use an indefinite determiner nějakou 'some' or jednu 'one' instead of the bare NP krávu 'cow', as in (44b), it is infelicitous to use the partitive complement $z$ nich 'of them' along with the indefinite determiner, see $(44 \mathrm{c})$. Intuitively, the reason is that the context does not support the existence of a particular domain of cows. ${ }^{38}$

38 The standard assumption about cases like (44b), where a determiner occurs without any restriction is that the NP restriction is elided. Czech has no NP proforms like the English one. The numeral jednu 'one' is used as a determiner in this case. For a general discussion about the syntax of the Czech nominal phrase, see Veselovská 1995. 
The role of givenness, presupposition, and prosody in Czech word order

(44) Indefinite context: 'We mainly keep poultry and smaller domestic animals on our farm. Since last year we haven't had any cows.'

a. To je zvláštní, mám pocit, že jsem před chvílí that is strange have.1SG feeling.ACC that AUX.1SG before while krávu viděl.

cow.ACC saw

'That's strange, I have the feeling that a while ago I saw a cow.'

b. To je zvláštní, mám pocit, že jsem před chvílí that is strange have.1SG feeling.ACC that AUX.1SG before while nějakou/jednu viděl.

some/one.ACC saw

'That's strange, I have the feeling that a while ago I saw one.'

c. \#To je zvláštní, mám pocit, že jsem před chvílí that is strange have.1SG feeling.ACC that AUX.1SG before while nějakou/jednu z nich viděl.

some/one.ACC of them.GEN saw

'That's strange, I have the feeling that a while ago I saw one of them.'

(45) combined with (45a) represents the type of item where a partitive interpretation is possible. We infer this from the fact that it is felicitous to use the negative concord determiner žádného 'no' along with the partitive complement $z$ nich 'of them', as in (45c). Yet, this interpretation is not necessary. First, it is not necessary to use the partitive complement, as seen in (45b). Moreover, intuitively, neither (45a) nor (45b) entail that the negative statement is limited to the architects that were part of the working group. Both are compatible with a stronger reading which denies the meeting of any architect whatsoever. That latter reading corresponds to a non-partitive use of the indefinite.

(45) Indefinite context: 'Our working group has been great so far, but last week somehow all the architects disappeared.'

a. Máš pravdu, tento týden už jsme tady have.2SG truth.ACC this week.ACC already AUX.1PL here architekta nepotkali. architect.ACC NEG.met

'You're right, this week we haven't met any architect here.' 

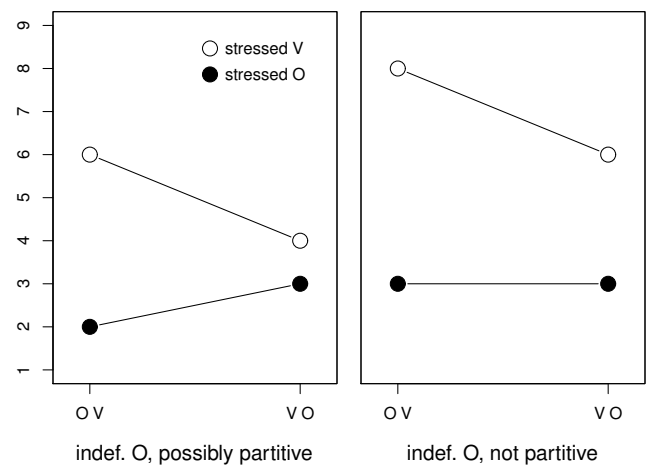

order possibly part. not part.

\begin{tabular}{lll}
\hline OV & $\mathbf{6}(3)$ & $\mathbf{8}(3)$ \\
$\overline{\mathrm{V}}$ & $\mathbf{4}(5)$ & $\mathbf{6}(4)$ \\
$\mathrm{OV}$ & $\mathbf{2}(2)$ & $\mathbf{3}(3)$ \\
$\overline{\mathrm{V}}$ & $\mathbf{3}(4)$ & $\mathbf{3}(6)$
\end{tabular}

Figure 7 Results of the post-hoc analysis for partitive interpretation; medians in boldface, IQR in parentheses

b. Máš pravdu, tento týden už jsme tady have.2SG truth.ACC this week.ACC already AUX.1PL here žádného nepotkali.

no.NCI.DET.ACC NEG.met

'You're right, this week we haven't met one here.'

c. Máš pravdu, tento týden už jsme tady have.2SG truth.ACC this week.ACC already AUX.1PL here žádného $\quad z$ nich nepotkali. nO.NCI.DET.ACC of them.GEN NEG.met 'You're right, this week we haven't met any one of them here.'

The results of the post-hoc analysis are summarized in Figure 7.

In the relevant OV structure, the results go against the hypothesis that scrambled indefinites can only be acceptable when they have a partitive interpretation: in fact, these indefinites were rated lower than those without a salient partitive interpretation (marginally significant: $z=2.38, p=0.05$ after Holm-Bonferroni correction ${ }^{39}$ ). We tentatively conclude that a potentially partitive interpretation was not the reason for the ability of the indefinites to scramble.

39 For the post-hoc analyses in Sections 5.2 through 5.5, in which we always divided the items into two groups, we treated the four comparisons that we made between these groups (one for each condition) as a family of tests for purposes of significance level correction, unless stated otherwise. 
The role of givenness, presupposition, and prosody in Czech word order

In addition, we found a significant penalty for indefinites allowing a partitive interpretation in the stress shift structure $(z=2.67, p=0.03)$. The possibly partitive items behaved similarly to the definite ones in this condition, as it was shown in the discussion of the main results of experiment 1. This could mean that partitive indefinites share the property that is responsible for this contrast with definites. (They are both presupposed, in the sense defined in Section 3.1.1.) However, in contrast to the comparison between indefinites and definites, no difference was found for the Vo condition between the two groups of indefinites $(z=0.13, p=0.90)$. There was no significant difference in the $\underline{\mathrm{OV}}$ condition, either $(z=1.40, p=0.16)$.

\subsection{Scope}

An anonymous reviewer wonders whether some of the indefinite objects in our items could potentially be scope ambiguous and whether the ambiguity might have influenced the results. The idea is that although we show that indefinites can scramble, this might be limited to indefinites with a wide scope interpretation. In order to test this hypothesis, we performed a posthoc analysis of the indefinite half of our items.

Seven of the 39 items contained sentential negation. In none of the cases was it possible to interpret the indefinite as taking wide scope with respect to the negation according to the intuition of RŠ. ${ }^{40}$ An example of this is in (46).

(46) Indefinite context: 'Did you know that the Americans sent a unit specialized on terrorists to Iraq?'

Jo, už před rokem, ovšem ještě teroristu

yes already before year.INSTR but yet terrorist.ACC

nevypátrali.

NEG.tracked.down

a. Possible: 'Yes, already a year ago, but they haven't tracked any terrorist down yet.'

b. Impossible: 'Yes, already a year ago, but they haven't tracked some (specific) terrorist down yet.'

If the reviewer's hypothesis that only wide scope indefinites can scramble is on the right track, then the impossibility of a wide scope interpretation with

40 In fact, it seems that indefinite bare NPs resist wide scope interpretations completely - a crosslinguistically valid observation (see Dayal 2011 for recent discussion). It is possible that wide scope must be explicitly marked (e.g. by using a certain indefinite determiner). 

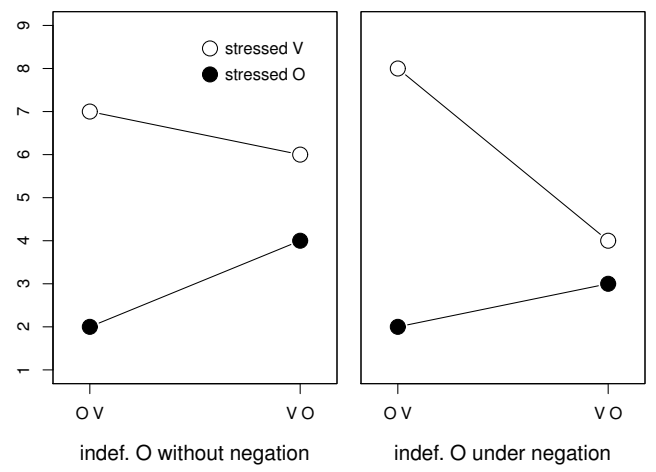

order no NEG. under NEG.

\begin{tabular}{lll}
\hline OV & $7(3)$ & $8(3)$ \\
$\overline{\text { VO }}$ & $6(5)$ & $4(5)$ \\
$\overline{O V}$ & $2(3)$ & $2(3)$ \\
$\overline{\text { VO }}$ & $4(4)$ & $3(4)$
\end{tabular}

Figure 8 Results of the post-hoc analysis for narrow scope under negation; medians in boldface, IQR in parentheses

respect to negation in cases like (46) should be reflected in relatively lower ratings of the scrambled conditions. In Figure 8, we compare the scores of the items with an indefinite object under sentential negation to the remainder of the items with an indefinite object (without negation). The visible trend goes against the predictions: indefinites with narrow scope with respect to negation are better in scrambled positions in comparison to the average indefinite object, and worse in situ. None of the differences reached statistical difference after Holm-Bonferroni correction ( $\underline{\mathrm{OV}}: z=2.01, p=0.18$; VO : $z=1.99, p=0.14$; V $\underline{\mathbf{O}}: z=0.58, p=1$; $\underline{\mathrm{OV}}: z=0.07, p=0.94$ ).

\subsection{Verb contrast}

Although we made sure not to provide verbs in our contexts that would explicitly contrast with the verb in the target sentence, some of the verbs in experiment 1 are nevertheless compatible with a contrastive interpretation. An example of this is, again, the item (36), repeated below, where the verb našel 'found' can be interpreted as contrasting with parts of the preceding claim. More particularly, the type of contrast implicated here is verum focus: the response negates the claim in the context that there are no rats by suggesting that there is one. 
The role of givenness, presupposition, and prosody in Czech word order

(47) Indefinite context: 'I don't know what you are talking about. There have never been rats in our cellar.'

a. No, volal mi Jirka, že prý právě potkana well called me.DAT Jirka.NOM that allegedly just $\overline{\text { rat.ACC }}$ objevil.

found

'Well, Jirka called and said that he has just found a rat.'

b. No, volal mi Jirka, že prý právě objevil potkana.

An anonymous reviewer suggests that under Kučerová's theory, such verb contrast could be held responsible for the relatively high rating of the VO condition, exemplified in (47b): even though Kučerová does not allow for stress shift for givenness reasons, stress shift is allowed if it is for reasons of contrast. (For the sake of this argument we ignore Kučerová's claim that stress shift is only possible in generic contexts, which were excluded from our items; see Section 3.1.4 for discussion.) Interestingly, not all items made the verb contrast interpretation as salient as (47). An example of this is in (48), where the verb poobédvat 'eat for lunch' contrasts with nothing in the context. Of course, some sort of accommodation of contrast is not ruled out (perhaps 'eat for lunch' vs. 'eat for dinner') but we hold it for unlikely. Therefore, analyzing (48b) in terms of stress shift for contrast reasons is not very plausible.

(48) Indefinite context: 'They say they have fresh salmon on the market.'

a. Tak to bychom zítra mohli lososa poobědvat. so part would.1PL tomorrow could salmon.ACC eat.for.lunch 'So we could have a salmon for lunch tomorrow.'

b. Tak to bychom zítra mohli poobědvat lososa.

Kučerová's assumption that stress can shift for contrast in conjunction with the assumptions considered above yields two predictions:

i. $\mathbf{V}_{[+c]} \mathrm{O}$ should be more acceptable than $\mathbf{V}_{[-c]} \underline{O}$. (Contrast on the verb attracts stress.)

ii. $\mathrm{V}_{[-\mathrm{c}]} \mathbf{O}$ should be more acceptable than $\mathbf{V}_{[-c]} \underline{\mathrm{O}}$. (In the absence of verb contrast, there should be default sentence stress on the object; we only consider this prediction for indefinite items because definite ones obligatorily scramble under Kučerová's assumptions, so there are no

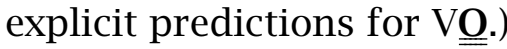



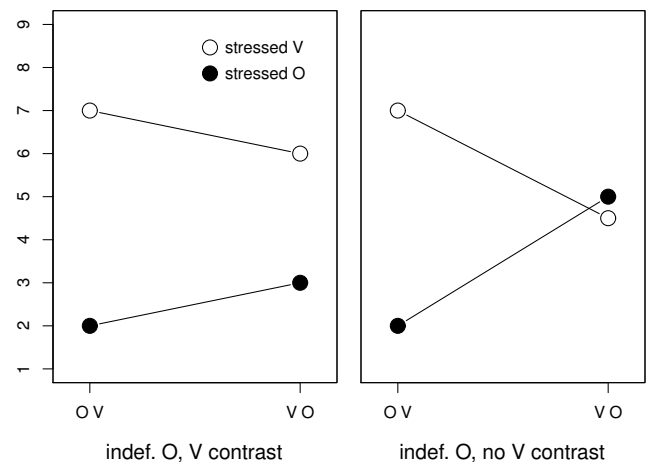

order V contr. no V contr.

\begin{tabular}{llr}
\hline OV & $7(4)$ & $7(3)$ \\
$\overline{\text { VO }}$ & $6(4)$ & $4.5(3.5)$ \\
$\overline{O V}$ & $2(3)$ & $2(3)$ \\
$\overline{\text { VO }}$ & $3(5)$ & $5(5)$
\end{tabular}

Figure 9 Results of the post-hoc analysis for salient verb contrast in the indefinite contexts; medians in boldface, IQR in parentheses
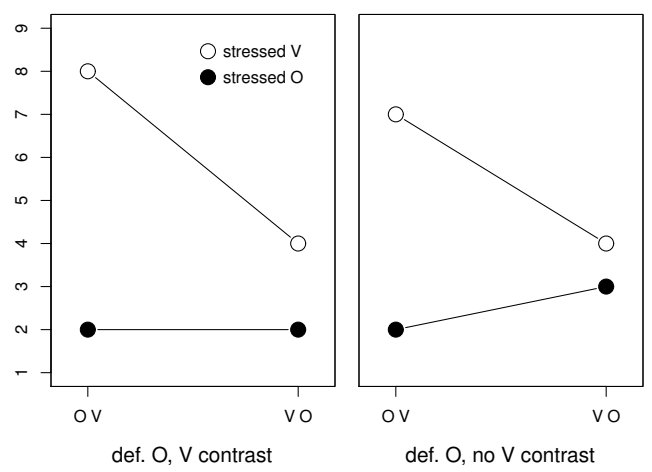

order V contr. no V contr.

\begin{tabular}{lll}
\hline$\underline{\underline{\mathrm{OV}}}$ & $8(3)$ & $7(5)$ \\
$\mathrm{V} \underline{\underline{\mathrm{O}}}$ & $4(3)$ & $4(4)$ \\
$\underline{\underline{\mathrm{V}}}$ & $2(3)$ & $2(3)$ \\
$\underline{\mathrm{O}}$ & $2(3)$ & $3(3)$
\end{tabular}

Figure 10 Results of the post-hoc analysis for salient verb contrast in the definite contexts; medians in boldface, IQR in parentheses

In order to test these prediction, we annotated all the items for whether verb contrast interpretation is likely in them. The annotation was done separately for indefinite and definite contexts. In indefinite contexts we found that 22 items make verb contrast interpretations likely, 11 unlikely, the remaining 6 being difficult to decide on. In definite contexts 20 items make verb contrast interpretations likely, 13 unlikely, the remaining 6 being difficult to decide on. The results are summarized in Figures 9 and 10.

Kučerová's first prediction is borne out: stress shift is significantly more acceptable in the conditions with an indefinite object when a contrastive interpretation of the verb is more likely $(z=2.61, p=0.04)$. On the other hand, among the items with a definite object, there is no significant difference 
The role of givenness, presupposition, and prosody in Czech word order

between the two groups in the stress shift condition $(z=1.67, p=0.29)$. As for Kučerová's second prediction, we indeed see a small trend for default stress (VO) having a higher median than stress shift (VO) in the absence of verb contrast for indefinite objects, although this difference does not reach a significant level $(z=0.59, p=0.56) .{ }^{41}$ Similarly, among the items containing a definite object, we also see a reduced difference between default stress and stress shift. And in this case as well, there is no significant difference between default stress and stress shift in the absence of verb contrast $(z=1.97$, $p=0.19)$.

In summary, our post-hoc analysis revealed an important interaction between contrast and prosody. The results corroborate Kučerová's idea that shifting sentence stress away from indefinite objects is facilitated by contrast. On the other hand, it can be noted that the trends in this post-hoc analysis do not fully support the assumption that mere givenness cannot license stress shift (labeled the "third component" of Kučerová's system in Section 3.2): it seems to be the case that the reduced difference between stress shift (VO) and default stress (VO) in the absence of verb contrast mainly stems from increased acceptability of default stress, and less so from decreased acceptability of stress shift. This might suggest - using the terminology of the prosodic approach - that the weight of a violation of the *STRESS-GIVEN constraint depends on the contrastivity of the adjacent constituent: it seems to be more problematic to stress a given object if the preceding verb is contrastive. This effect should be investigated in more detail in future research by controlling more systematically for the possibility of contrast accommodation; if the observation can be confirmed, it would support Wagner's (2012) view that givenness and focus are tightly linked (see footnote 7 ).

Note that the results of this post-hoc analysis do not influence the evaluation of the other two components of Kučerová's theory (the G-operator and the economy principle), since they only make predictions concerning word order, not stress patterns. As for the prosodic approach, these results could suggest that the *STRESS-GIVEN constraint should either be complemented by an additional contrast-related constraint, or that it should be replaced by a more complex constraint making reference to both givenness and contrast, or that it should be decomposed into multiple constraints. In order to decide between these options, more data is needed. In the remainder of the paper,

41 In this case, the Holm-Bonferroni correction involved adjustment for this additional comparison within one of the groups. 
Šimík \& Wierzba

we will continue to use the simple version of *STRESS-GIVEN as it was defined in Section 3.2.

\subsection{PP contrast}

As pointed out by an anonymous reviewer, there is a potential confound in experiment 2 that has to do with contrast on the PP. In some of our items, a contrast between the PP in the target sentence and a PP in the context was salient, as exemplified in (49), where 'to the garage' could be perceived as contrasting with 'from the carwash'. In other items there was no such salient contrast (e.g. in (50)).

(49) New PP, definite object NP. Context: 'I've just come back from the carwash. The car is washed now.'

Měli byste ještě zavézt auto do garáže. should subj.2PL still take car.Acc to garage.LOC

'You should still take the car to the garage.'

(50) New PP, definite object NP. Context: 'In the communist time Olga and her son must have had a hard life.'

To je pravda, věděla jsi, že Olga porodila that is truth.NOM knew AUX.PAST.2SG that Olga.NOM gave.birth syna ve vězení?

son.ACC in prison.LOC

'That's true, did you know that Olga give birth to her son in prison?'

Again, we annotated the items according to Řs's intuitions. In the items in which the PP was given, there was never a salient contrast. Within the items with a new PP, it turned out that salient PP contrast occurred only in items containing a definite object. (For two of them, there was no salient contrast, and for three of them there was.) However, we did not find a difference between these two (admittedly very small) groups of items: the median was 8 for both groups, and there was no significant difference $(z=0.37, p=0.72)$.

\subsection{Summary of the post-hoc confound analyses}

In view of our post-hoc tests, it seems safe to conclude that indefinites can indeed scramble in Czech: the scrambled structure turned out to be the best option of realizing an indefinite given object and a new verb, irrespective of 
The role of givenness, presupposition, and prosody in Czech word order

partitivity, scope, and contrastivity. It also does not seem to be the case that the similar scrambling behavior of definite and indefinite objects stems from the possibility of interpreting the object as indefinite in our contexts that were supposed to trigger a definite interpretation; this potential confound was tested in a forced choice test, and it was shown that removing the items in which such an undesired interpretation was more likely would not change the results in a relevant way. On the other hand, we do find an interesting influence of contrast in that the acceptability of stress shift is raised when a contrastive interpretation is more likely. Since this finding is based only on a post-hoc analysis, we will not incorporate it into our analysis in this paper; however, we think that this factor is worth being investigated in more detail in future work.

\section{General discussion}

Both the prosodic theory and Kučerová's $G$-marking theory have their merits and problems in explaining our experimental findings. In this final section, we try to shed more light on the complex relation between the findings and the theories. We conclude that the prosodic theory is better suited to model the facts we observe but must be supplemented with an independent word order regulating device which is based on presupposition.

\subsection{Evaluation of Kučerová's theory}

The predictions of Kučerová's theory in its full power differ substantially from what we see in the results. Yet, it is important to keep in mind that it is a relatively independent assumption that is responsible for some of these differences: the idea that Czech scrambling is regulated by an economy condition and scrambling is prohibited if it does not lead to presuppositionmarking that would be unavailable otherwise. This assumption leads to two wrong predictions:

i. that scrambling of given indefinite objects should be worse than leaving them in situ, and

ii. that scrambling of given definite objects should be better than scrambling of given indefinite objects.

If the economy condition was stripped away from the core idea that propositions are partitioned into a given+presupposed area and the rest, Kučerová's 
theory would capture a part of the results of experiment 1: It is indeed the case that scrambling a given+presupposed object over the verb is much better than leaving it in situ (i.e., if default stress assignment is maintained). Also, it is the case that leaving an indefinite object in situ is better than leaving a definite object in situ. Yet, this part of the theory runs into a problem with experiment 2, where VOPP (a new-given-new sequence) is predicted to be better than VOPP (a new-given+preupposed-new sequence), contrary to what we found. Also, in experiment 1, it remains unexplained why scrambling a given indefinite should be better than leaving it in situ. According to a post-hoc analysis of our data, we did not find any support for the hypothesis that the indefinites in our items were interpreted as implicit partitives (or, if they were interpreted as such, it had no effect), nor did we find any support for a word order-based scope ambiguity of the indefinites.

The area where Kučerová's theory provides insight is the effect of definiteness on word order. Remember that in experiment 1 we used definiteness as a proxy to Kučerová's notion of givenness: whereas all objects were given in the sense of discourse-salience (see Section 2.2), only definite objects were given+presupposed in the sense of Kučerová (see Section 3.1.1). And indeed, our results yielded an interesting effect of definiteness: while there was no difference between definites and indefinites in the scrambled position (contrary to Kučerová's predictions, see above), we found a difference between the two when they were in situ: indefinites tolerate the in situ position more easily than definites. We found a comparable though qualitatively different effect in experiment 2, where definite objects were more acceptable than indefinite ones. This can be attributed to the fact that the PP which these objects preceded invariably contained a definite NP. If there is a definiteindefinite ordering preference, as Kučerová's work suggests, $\mathrm{NP}_{\text {ind }} \mathrm{P} \mathrm{NP}_{\text {def }}$ is indeed expected to be worse than $\mathrm{NP}_{\text {def }} \mathrm{P} \mathrm{NP}_{\text {def }}$. Yet, the findings suggest that an adjustment is needed in the exact formulation of the ordering preference, and importantly, we believe that this ordering preference is at work independently of the prosody-givenness interaction which motivates scrambling. We get back to this issue in Section 7.

Another idea from Kučerová (2007: 125) for which we found evidence in a post-hoc analysis is that contrast plays a significant role in the acceptability of stress shift. It seems to be indeed the case that givenness of the object alone is not sufficient to license stress shift to the verb, which seems to support Wagner's (2012) stronger notion of givenness. This effect should be investigated more systemically in future work. 
The role of givenness, presupposition, and prosody in Czech word order

\subsection{Evaluation of the prosodic theory}

A part of the pattern found in experiment 1 is predicted by the prosodic theory. Scrambling combined with rightmost stress assignment is the best option for both definite and indefinite objects. This follows from the prosodic theory as it is the only condition in which neither NSR-I nor *STRESS-GIVEN is violated. Scrambling combined with stress on the object is found to be the worst option. This too is predicted as both NSR-I and *STRESS-GIVEN are violated. Most of the other conditions were rated intermediately, which corresponds to the violation of either NSR-I or *STRESS-GIVEN, the only exception being the in situ definite object condition, which was rated as bad as the worst option (scrambling plus stress shift). Such comparably bad rating for definite as opposed to indefinite NPs is unexpected.

Concerning experiment 2, there too the prosodic theory captures some of the observed differences. In particular, the conditions where the stressed PP is given are rated much worse than the conditions where it is new. This is expected as the former but not the latter violates *STRESS-GIVEN. The fact that definite objects were found to be more acceptable than indefinite ones remains unexplained by the prosodic theory.

In summary, the prosodic theory models our experimental findings well in general; however, the effects of definiteness which we find both in experiment 1 and 2 remain unexplained. This shows that the prosodic theory is not sufficient as a model for word order in Czech: something must be added.

\subsection{Combining the theories?}

So far, we have established that neither the $G$-movement theory nor the prosodic approach can account for the full range of data. The idea of a combined theory suggests itself: can the two accounts or parts of them be combined to a theory that is able to account for both the observed relation between prosody and givenness and for the effect of definiteness?

The $G$-movement theory is at heart incompatible with the prosodic approach in several respects. Under the prosodic theory, constraints concerning the interaction between prosody and word order (NSR-I) and the interaction between prosody and information structure ("STRESS-GIVEN) are assumed to cause syntactic reordering. In Kučerová 2007, 2012, the existence of a

systematic relation between accentuation and givenness in Czech is denied 
(see Section 3.1.4). It is argued that in Czech, givenness is marked by the $G$ operator instead. As an additional difference to prosodic givenness marking in English, givenness in the sense of discourse salience alone is assumed not to be sufficient for marking in Czech; given+presupposed elements are marked.

Only if we disentangle givenness and presupposition, does a division of labor within the theory in accounting for the results become possible to a certain extent. Our data show that there is a systematic relation between accentuation and givenness in Czech: sentence stress on a given element causes a strong decrease in acceptability. We also see that sentence stress preferably falls on the rightmost element in Czech, since structures with shifted stress are also decreased in acceptability. We propose that these two constraints in combination motivate scrambling of given objects, because only in a scrambled OV word order can both constraints be satisfied. Since scrambling is the optimal structure irrespective of whether the object is definite/presupposed or indefinite/non-presupposed, presupposition cannot be a necessary condition on scrambling. It does not seem to be a sufficient condition for scrambling, either, as experiment 2 shows that an indefinite/non-presupposed object is perfectly acceptable (or at least as acceptable as the scrambled structures in experiment 1) in a position following the (non-presupposed) verb, as long as it does not carry sentence stress. We conclude that presupposition is not involved in motivating or restricting scrambling in Czech. However, we did see a significant impact of presupposition on acceptability in both experiments: in experiment 1, indefinite objects were significantly better in situ than definite ones, and in experiment 2, definite objects were found to be more acceptable than indefinite ones. We propose to capture these findings by an additional constraint concerning the ordering of presupposed and non-presupposed elements. We will show that this component of our analysis makes predictions similar to those that would follow from a $G$-operator if it marked elements only as presupposed and was not be related to givenness in the sense of discourse-salience at all. We flesh out our proposal in more detail in the next section.

\section{Proposed analysis}

We have established that we need to represent the constraints *STRESSGIVEN and NSR-I in our model of Czech grammar if we want to account for the empirical data pattern. NSR-I restricts the prosodic form of a sentence; 
The role of givenness, presupposition, and prosody in Czech word order

*STRESS-GIVEN restricts the way in which the prosodic representation of a sentence can be mapped to its information-structural representation. Thus, the constraints can only apply after a prosodic representation was assigned to the sentence. We assume that in addition to a structure-building grammatical component, there is a post-derivational component that compares and evaluates the produced candidates. Linear Optimality Theory (LOT; Keller 2000) seems to be the most suitable framework for modeling fine-graded acceptability judgments like the ones that we find in our experiments without losing information. In Standard Optimality Theory (A. Prince \& Smolensky 1993/2002), only a single winner is determined among a set of candidates.

We think that adding explicit effect sizes to our model can be a useful descriptive tool that has the benefit of allowing to test the theory for consistency and to make very precise predictions. If further research involving different constructions reveals acceptability differences that can be fully accounted for by our model, this would provide evidence that the proposed constraints are really at play in Czech.

A core assumption of LOT is that "[t]he cumulativity of constraint violations can be implemented by assuming that the grammaticality of a structure is proportional to the weighted sum of the constraint violations it incurs" (Keller 2000, pp. 252-253). In other words, weights representing how bad a violation is are assigned to the constraints. The acceptability of a sentence can then be predicted by summing up the weights of the constraints that it violates.

We propose a model with three constraints: *STRESS-GIVEN, NSR-I and *NON-PRES $>$ PrES. The first two were described in detail in Section 3.2. *NoNPRES $>$ PRES is a new constraint that we introduce. It evaluates the mapping between the linear ordering of elements and their interpretation, and it is violated by structures in which non-presupposed expressions occur to the left of presupposed expressions. More particularly, this constraint is violated once for each non-presupposed expression that precedes one or more presupposed expressions.

(51) *NON-PRES>PRES: A non-presupposed expression does not linearly precede a presupposed expression.

Table 10 shows in which conditions of experiment 1 the constraints are satisfied/violated. We assume *STRESS-GIVEN to be violated in all conditions in which sentence stress falls on the given object. NSR-I is violated in those conditions in which sentence stress does not fall on the rightmost element, 
but is shifted to the left. *NON-PRES>PRES is violated in the two conditions in which a non-presupposed verb precedes a definite (presupposed) object. We estimated the effect size of the constraints by comparing conditions which only differ in whether this constraint is violated or satisfied in experiment 1. In contrast to Keller 2000, we did not estimate the effect size in raw scores, but we use Cliff's $\delta$ (Cliff 1993, 1996). This statistic can be used to calculate a more relative and scale-independent measure of effect size based on the degree of overlap between two distributions. When the two distributions are identical, $\delta$ is 0 ; if all observations in one of the groups are larger than in the other group, $\delta$ will be -1 or +1 . Romano et al. (2006) and Hess \& Kromrey (2004), among others, propose to use this statistic as an estimate of effect size for ordinal data. Romano et al. (2006) show that there is a specific relation between Cliff's $\delta$ and Cohen's $d$ (Cohen 1988); the latter is standardly used to report effect sizes for linguistic and psychological experiments. Cohen's $d$ can also be interpreted as degree of overlap, but it can only be used for normally distributed data. Cohen (1988:25-27) characterizes an effect size around $d=0.2$ as "small", an effect size of $d=0.5$ as "medium" (around this effect size, the contrast begins to be "visible to the naked eye"), and an effect size greater than $d=0.8$ as "large" ("grossly perceivable"). Romano et al. (2006) show that for two normally distributed populations, a Cliff's $\delta$ of 0.15 represents a degree of overlap corresponding to a "small" effect in Cohen's measure, a $\delta$ of 0.33 would correspond to a "medium" effect, and a $\delta$ of 0.47 to a "large" effect. Although this is not fully transferable to the case of non-normally distributed data, this relation can serve as a basis of comparison to other studies in which effect sizes are reported in terms of Cohen's $d$.

All relevant comparisons of pairs differing only in a violation of *STRESSGIVEN yielded an effect size in terms of Cliff's $\delta$ between 0.45 and 0.55 , between 0.2 and 0.3 for NSR-I, and also between 0.2 and 0.3 for *NoNPRES $>$ PRES. Translating that into Cohen's categorization, *STRESS-GIVEN has a large effect and the other two have a small to medium effect.

In experiment 2, the relevant comparisons reveal an effect size between 0.6 and 0.65 for *STRESS-GIVEN, and between 0.2 and 0.3 for *NON-PRES> PRES. (There is no condition violating NSR-I, so nothing can be deduced about that constraint from experiment 2.) This is consistent with the constraint weights estimated from experiment 1 to the extent that *STRESS-GIVEN has a large effect in both experiments and *NON-PRES $>$ PRES has a small to medium one. However, we find discrepancies in the exact numbers, especially for 
The role of givenness, presupposition, and prosody in Czech word order

\begin{tabular}{|c|c|c|c|c|c|c|}
\hline order/stress & def. & description & median (IQR) & $* S G$ & NSR-I & $* \mathrm{~N}-\mathrm{P}>\mathrm{P}$ \\
\hline$\underline{\underline{O}} \mathbf{V}$ & def. & scrambling & $7(3.5)$ & & & \\
\hline $\mathrm{V} \underline{\underline{O}}$ & def. & stress shift & $4(4)$ & & * & $*$ \\
\hline$\underline{\underline{\mathrm{OV}}}$ & def. & both & $2(3)$ & * & $*$ & \\
\hline $\mathrm{V} \underline{\underline{\mathrm{O}}}$ & def. & none & $2(3)$ & $*$ & & $*$ \\
\hline OV & ind. & scrambling & $7(3)$ & & & \\
\hline$\overline{\mathbf{V}} \mathrm{O}$ & ind. & stress shift & $6(5)$ & & $*$ & \\
\hline $\mathrm{OV}$ & ind. & both & $2(3)$ & $*$ & $*$ & \\
\hline$\overline{\mathrm{V}} \mathbf{O}$ & ind. & none & $3(4)$ & $*$ & & \\
\hline
\end{tabular}

Table 10 Constraint profile for experiment 1

\begin{tabular}{|c|c|c|c|c|c|}
\hline definiteness & PP & median (IQR) & $* S G$ & NSR-I & $* \mathrm{~N}-\mathrm{P}>\mathrm{P}$ \\
\hline def. & new & $8(3)$ & & & $*$ \\
\hline def. & given & $4(4)$ & $*$ & & $*$ \\
\hline ind. & new & $7(4)$ & & & $* *$ \\
\hline ind. & given & $3(3)$ & $*$ & & $* *$ \\
\hline
\end{tabular}

Table 11 Constraint profile for experiment 2

*STRESS-GIVEN. This could point at an additional factor being involved. One difference between experiment 1 and experiment 2 is that in the latter we were able to estimate the effect size of *STRESS-GIVEN by comparing a new and a given version of the same element in the same position because we manipulated the givenness of the PP, whereas in the former we had to compare across elements and across positions, since we kept the givenness of the elements constant. So the increased size of the *STRESs-GIVEN constraint in experiment 2 could mean that the category of the stressed element (direct object in experiment 1 vs. PP modifier in experiment 2) or its position (in situ or scrambled) matters as well.

Related to that, it has to be noted that we have not incorporated anything like a "cost" for movement operations, for instance by assuming a constraint like STAY that is violated by any syntactic movement (see Grimshaw 1997) or an economy condition restricting movement to where it is necessary (as found, e.g., in Reinhart's (2006) framework). We have been assuming that 
scrambling is a free optional operation in Czech. ${ }^{42}$ However, the difference in the effect size of *STRESS-GIVEN we find between experiment 1 and experiment 2 could point towards a small but significant penalty for scrambled vs. default structures. If this explanation is on the right track, then this could also shed light on the question why the best options in experiment 1, which do not violate any of our model's constraints but have a scrambled word order, are less acceptable than the best options in experiment 2, which violate *NoNPRES $>$ PRES once but have a default word order. Since we did not manipulate this factor systematically within one experiment, we leave this issue for future research.

As for the status of *NON-PRES $>$ PRES, we implemented it as a constraint applying post-derivationally just like the two other constraints. That definiteness plays a role for the relative linear ordering of elements has been proposed for other languages, as discussed by Lenerz (1977) for German or recently by Titov (2012) for Russian. The similarity of our constraint to restrictions that are assumed to be active in other languages is in line with our general proposal that no special machinery is required for Czech. The rather small effect size of the constraint and the fact that it seems to add up with violations of other constraints in a cumulative way favors the view that it should be represented at the same grammatical level as *STRESSGIVEN and NSR-I over the idea that it is operative during the derivation. If we wanted to maintain a mechanism similar to the $G$-operator to account for the observed definiteness effect, its functionality would need to be changed considerably: it would have to be related only to presupposition and say nothing about discourse-givenness, and we would need to assume that an improper insertion causes only a slight decrease in acceptability and not infelicity. The latter property seems to us to be at odds with the core idea of the $G$-operator, namely that its wrong insertion leads to too many or too few presuppositions. We would expect this to lead to a more severe decrease in acceptability, comparable to incorrect uses of the definite/indefinite article in English.

The model presented here allows us to make precise predictions for further empirical studies on givenness, presupposition and word order in Czech. So far we have only looked at given elements in situ and at very

42 In a framework where scrambling is derived by base-generation (e.g., Fanselow 2001), the derivational constraint STAY could be rephrased as the representational constraint *COMPLEMENT>HEAD. We thank Gisbert Fanselow (p.c.) for making us aware of this possibility. 
The role of givenness, presupposition, and prosody in Czech word order

local verb-object reordering. Our model in its current form predicts that it should also be possible to scramble a given element to a position further to the left. For instance, in structures like the ones tested in experiment 2 (VOPP), OVPP should also be an acceptable option, since *STRESS-GIVEN and NSR-I are still satisfied in this configuration (and nothing changes for the *NON-PRES $>$ PRES constraint). This was confirmed in a study reported in Šimík, Wierzba \& Kamali 2014, where no difference was found between OVPP and VOPP. Another prediction would be that adding more non-presupposed elements to the left of a presupposed object should lead to a decrease in acceptability.

The model can also be used to detect and quantify cross-linguistic differences. It is conceivable that between Czech and languages which also mark givenness prosodically there are differences with respect to the exact weights of the constraints. A first comparison between Czech and one such language can be drawn based on the study by Seiffe (2013), who investigated the impact of sentence stress and givenness on the ordering of a direct object and a PP adjunct in the German middlefield. She reports a mean acceptability rating of 5.93 (sd: 1.4) on a 7-point scale for the scrambled OPP structure, 4.67 (1.81) for the PPO structure with stress shift, 3.36 (1.77) for OPP with both scrambling and stress shift, and 3.79 (1.88) for PPO with default order and default stress. From these values, a Cohen's $d$ between 0.7 and 1.3 (which would correspond to a "large" effect) can be estimated for the effect of *STRESS-GIVEN in German, and of 0.5 ("medium") for NSR-I. We take this as a first hint that the prosodic givenness marking systems of Czech and German could be indeed very similar, even to the extent of the effect sizes of constraint violations.

\section{Conclusion}

We conclude that Czech does not have a givenness marking system that is completely different from the system that we find in English or German. We have shown that the requirement to deaccent given elements in conjunction with a default sentence stress rule successfully account for a large part of the data about the behavior of given elements in Czech. We proposed to model these constraints in the framework of Linear Optimality Theory by assuming a weight for *STRESS-GIVEN that corresponds to a large effect size in terms of Cohen (1988) and a weight corresponding to a small to medium effect size for NSR-I. We have shown that the $G$-movement theory proposed 
by Kučerová $(2007,2012)$ does not provide a suitable alternative view on our data, because it incorrectly predicts that presupposition should be a necessary condition for scrambling (experiment 1 showed that non-presupposed objects do scramble), and that a partitioning between given and new elements should be obligatory (experiment 2 showed that a given object can follow a new verb, if the object is not in the stress-bearing sentence-final position).

In addition to that, we do find an interaction of word order and presupposition, which corroborates Kučerová's idea that this property also influences the acceptability of word order options in Czech. We incorporated this into our model by adding the constraint *NON-PRES $>$ PRES with a small to medium weight that is violated by each non-presupposed element preceding a presupposed one.

In this paper we have aimed at establishing generalizations concerning several aspects of the surface form of Czech sentences, such as the prosodic form and linear word order. So far our model is compatible with almost all theoretical approaches to scrambling, concerning questions such as whether it should be thought of as base-generation or movement, how it is triggered, and so on. However, at least as far as our data is concerned, it does not seem necessary to make reference to givenness within narrow syntax, since the observed pattern can fully be explained by rules applying at the syntaxprosody interface.

Some questions remain open: Should we think of Czech scrambling as a free or a costly operation? We found a small inconsistency in effect sizes between experiment 1 and experiment 2 that could point to the latter. What role does contrast play? Or, more generally, how would other informationstructural categories interact with the factors that we manipulated? We saw that verb contrast might have an influence on the acceptability of stress shift. Concerning the envisioned account of the relation between presupposition and word order: What is the nature of the factor or factors that interact with word order? In this paper, we considered it to be presupposition in a rather liberal understanding of the term. Can the effect of more specific factors such as definiteness, specificity, or scope be isolated? These questions are left to be addressed in future work, in which the empirical range should be broadened by including further constructions, further factors, and potentially further languages. 
The role of givenness, presupposition, and prosody in Czech word order

\section{References}

Abney, Stephen. 1987. The English noun phrase in its sentential aspect. Cambridge, MA: Massachusetts Institute of Technology PhD thesis.

Arnaudova, Olga. 2003. Focus and Bulgarian clause structure. University of Ottawa PhD thesis.

Arregi, Karlos. 2002. Focus on Basque movements. Cambridge, MA: Massachusetts Institute of Technology $\mathrm{PhD}$ thesis.

Biskup, Petr. 2011. Adverbials and the phase model (Linguistik Aktuell/Linguistics Today). Amsterdam: John Benjamins. http://dx.doi.org/10.1075/ la.177.

Bošković, Željko. 20o9a. More on the no-DP analysis of article-less languages. Studia Linguistica 63(2). 187-203. http:// dx.doi.org/10.1111/j.14679582.2009.01158.x.

Bošković, Željko. 20ogb. Scrambling. In Sebastian Kempgen, Peter Kosta, Tilman Berger \& Karl Gutschmidt (eds.), The Slavic languages: An international handbook of their structure, their history and their investigation, vol. 1 (Handbooks of Linguistics and Communication Science), 714-725. Berlin \& New York, NY: de Gruyter.

Büring, Daniel. 2001. Let's phrase it! Focus, word order, and prosodic phrasing in German double object constructions. In Gereon Müller \& Wolfgang Sternefeld (eds.), Competition in syntax (Studies in Generative Grammar), 69-105. Berlin: de Gruyter.

Büring, Daniel \& Rodrigo Gutiérrez-Bravo. 2001. Focus-related word order variation without the NSR: A prosody-based crosslinguistic analysis. Syntax and Semantics at Santa Cruz 3. 41-58.

Chomsky, Noam. 1971. Deep structure, surface structure, and semantic interpretation. In Danny Steinberg \& Leon Jakobovits (eds.), Semantics: An interdisciplinary reader in philosophy, linguistics, and psychology, 183-216. Cambridge: Cambridge University Press.

Chomsky, Noam \& Morris Halle. 1968. The sound pattern of English. New York, NY: Harper \& Row.

Christensen, R. H. B. 2013. Ordinal-Regression Models for Ordinal Data. R package version 2013.9-30. http://www.cran.r-project.org/package= ordinal/.

Christophersen, Paul. 1939. The articles: A study of their theory and use in english. Copenhagen: Munksgaard. 
Cliff, Norman. 1993. Dominance statistics: Ordinal analyses to answer ordinal questions. Psychological Bulletin 114(3). 494-509. http://dx.doi.org/10. 1037/0033-2909.114.3.494.

Cliff, Norman. 1996. Answering ordinal questions with ordinal data using ordinal statistics. Multivariate Behavioral Research 31(3). 331-350. http: //dx.doi.org/10.1207/s15327906mbr3103_4.

Cohen, Jacob. 1988. Statistical power analysis for the behavioral sciences. 2nd edn. Hillsdale, NJ: Erlbaum.

Daneš, František. 1957. Intonace a věta ve spisovné češtině. Praha: Československá akademie věd.

Dayal, Veneeta. 2011. Bare noun phrases. In Claudia Maienborn, Klaus von Heusinger \& Paul Portner (eds.), Semantics: An international handbook of natural language meaning, 1088-1109. Berlin: de Gruyter.

Déprez, Viviane. 1989. On the typology of syntactic positions and the nature of chains. Cambridge, MA: Massachusetts Institute of Technology PhD thesis.

Elbourne, Paul. 2008. Demonstratives as individual concepts. Linguistics and Philosophy 31(4). 409-466. http://dx.doi.org/10.1007/s10988-008-9043-0.

Elbourne, Paul. 2013. Definite descriptions (Oxford Studies in Semantics and Pragmatics). Oxford: Oxford University Press.

Enç, Mürvet. 1991. The semantics of specificity. Linguistic Inquiry 22(1). 1-25. http://www.jstor.org/stable/4178706.

Fanselow, Gisbert. 2001. Features, $\theta$-roles, and free constituent order. Linguistic Inquiry 32(3). 405-438. http://www.jstor.org/stable/4179156.

Fanselow, Gisbert. 2012. Scrambling as formal movement. In Ivona Kučerová \& Ad Neeleman (eds.), Contrasts and positions in information structure, 267-295. Cambridge: Cambridge University Press.

Féry, Caroline \& Vieri Samek-Lodovici. 2006. Focus projection and prosodic prominence in nested foci. Language 82(1). 131-150. http://dx.doi.org/10. 1353/lan.2006.0031.

von Fintel, Kai. 1994. Restrictions on quantifier domains. Amherst, MA: University of Massachusetts $\mathrm{PhD}$ thesis.

Fodor, Janet D. 2002. Prosodic disambiguation in silent reading. North East Linguistic Society (NELS) 32. 112-132.

Fox, Danny. 1995. Economy and scope. Natural Language Semantics 3(3). 283-341. http://dx.doi.org/10.1007/BFo1248820.

Fox, Danny. 2000. Economy and semantic interpretation (Linguistic Inquiry Monographs). Cambridge, MA: MIT Press \& MIT Working Papers in Linguistics. 
The role of givenness, presupposition, and prosody in Czech word order

Frege, Gottlob. 1892. Über Sinn und Bedeutung. Zeitschrift für Philosophie und philosophische Kritik 100. 25-50.

Grimshaw, Jane. 1997. Projections, heads and optimality. Linguistic Inquiry 28(3). 373-422. http://www.jstor.org/stable/4178985.

Halliday, Michael A. K. 1967. Notes on transitivity and theme in English: Part 2. Journal of Linguistics 3(2). 199-244. http://dx.doi.org/10.1017/ Soo22226700016613.

Hamlaoui, Fatima. 2009. La focalisation à l'interface de la syntaxe et de la phonologie: Le cas du français dans une perspective typologique. Université Paris 3 Sorbonne Nouvelle PhD thesis.

Hamlaoui, Fatima. 2011. On the role of phonology and discourse in Francilian French wh-questions. Journal of Linguistics 47(1). 129-162. http://dx.doi. org/10.1017/Soo22226710000198.

Haviland, Susan \& Herbert Clark. 1974. What's new? Acquiring new information as a process in comprehension. Journal of Verbal Learning and Verbal Behavior 13(5). 512-521. http://dx.doi.org/10.1016/Soo22-5371(74)80003-4. Heim, Irene. 1982. The semantics of definite and indefinite noun phrases. Amherst, MA: University of Massachusetts PhD thesis.

Heim, Irene. 1991. Artikel und Definitheit. In Arnim von Stechow \& Dieter Wunderlich (eds.), Semantics: An international handbook of contemporary research (Handbooks of Linguistics and Communication Science), 487-535. Berlin: de Gruyter.

Hess, Melinda R. \& Jeffrey D. Kromrey. 2004. Robust confidence intervals for effect sizes: A comparative study of Cohen's $d$ and Cliff's $\delta$ under nonnormality and heterogeneous variances. Paper presented at the Annual Meeting of the American Educational Research Association. San Diego, CA.

Horváth, Júlia. 2010. Discourse features, syntactic displacement, and the status of contrast. Lingua 120(6). 1346-1369. http://dx.doi.org/10.1016/j. lingua.2008.07.011.

Jackendoff, Ray. 1972. Semantic interpretation in generative grammar. Cambridge, MA: MIT Press.

Kamp, Hans. 1981. A theory of truth and semantic representation. In Jeroen Groenendijk, Theo Janssen \& Martin Stokhof (eds.), Formal methods in the study of language, 277-321. Amsterdam: Mathematical Centre.

Keller, Frank. 2000. Gradience in grammar. University of Edinburgh $\mathrm{PhD}$ thesis. 
Kučerová, Ivona. 2007. The syntax of givenness. Cambridge, MA: Massachusetts Institute of Technology $\mathrm{PhD}$ thesis.

Kučerová, Ivona. 2008. Givenness and maximize presupposition. Sinn und Bedeutung (SuB) 12. 353-366.

Kučerová, Ivona. 2012. Grammatical marking of givenness. Natural Language Semantics 20(1). 1-30. http://dx.doi.org/10.1007/s11050-011-9073-y.

Ladd, D. Robert. 1980. The structure of intonational meaning. Bloomington, IN: Indiana University Press.

Leiner, Dominik J. 2014. Sosci survey (computer software, version 2.4.oo-i). https://www.soscisurvey.de.

Lenerz, Jürgen. 1977. Zur Abfolge nominaler Satzglieder im Deutschen. Tübingen: Narr.

Mahajan, Anoop. 1990. The A/A'-distinction and movement theory. Cambridge, MA: Massachusetts Institute of Technology $\mathrm{PhD}$ thesis.

Mathesius, Vilém. 1939. O tak zvaném aktuálním členění větném. Slovo a slovesnost 5(4). 171-174. http://sas.ujc.cas.cz/archiv.php?lang=en\&art= 308.

Mykhaylyk, Roksolana. 2011. Middle object scrambling. Journal of Slavic Linguistics 19(2). 231-272.

Neeleman, Ad \& Tanya Reinhart. 1998. Scrambling and the PF interface. In Miriam Butt \& Wilhelm Geuder (eds.), The projection of arguments: Lexical and compositional factors, 309-353. Stanford, CA: CSLI Publications.

Pereltsvaig, Asya. 2007. On the universality of DP: A view from Russian. Studia Linguistica 61(1). 59-94. http:// dx. doi.org/10.1111/j.14679582.2007.00129.x.

Petř́k, Stanislav. 1938. O hudební stránce stredočeské věty. Praha: Filosofická fakulta University Karlovy.

Prince, Alan \& Paul Smolensky. 1993/2002. Optimality theory: Constraint interaction in generative grammar. Technical report, Rutgers and University of Colorado.

Prince, Ellen. 1981. Toward a taxonomy of given-new information. In Peter Cole (ed.), Radical pragmatics, 223-255. New York, NY: Academic Press.

R Core Team. 2013. R: A Language and Environment for Statistical Computing. R Foundation for Statistical Computing. Vienna, Austria. http://www.Rproject.org/.

Reinhart, Tanya. 1995. Interface strategies. In OTS working papers in theoretical linguistics 95-002. OTS, Utrecht University. 
The role of givenness, presupposition, and prosody in Czech word order

Reinhart, Tanya. 2006. Interface strategies: Optimal and costly computations. Cambridge, MA: MIT Press.

Roberts, Craige. 2002. Demonstratives as definites. In Kees van Deemter \& Rodger Kibble (eds.), Information sharing: Reference and presupposition in language generation and interpretation, 89-136. Stanford, CA: CSLI Publications.

Rochemont, Michael. 1986. Focus in generative grammar. Philadelphia, PA: John Benjamins.

Romano, Jeanine, Jeffrey D. Kromrey, Jesse Coraggio \& Jeff Skowronek. 2006. Appropriate statistics for ordinal level data: Should we really be using $t$-test and Cohen's $d$ for evaluating group differences on the NSSE and other surveys? Paper presented at the Annual Meeting of the Florida Association of Institutional Research. Cocoa Beach, FL.

Rooth, Mats. 1992. A theory of focus interpretation. Natural Language Semantics 1(1). 75-116. http://dx.doi.org/10.1007/BFo2342617.

Russell, Bertrand. 1905. On denoting. Mind 14(4). 479-493. http://dx.doi.org/ 10.1093/mind/XIV.4.479.

Samek-Lodovici, Vieri. 2005. Prosody-syntax interaction in the expression of focus. Natural Language \& Linguistic Theory 23(3). 687-755. http: //dx.doi.org/10.1007/s11049-004-2874-7.

Schwarzschild, Roger. 1999. Givenness, AvoidF and other constraints on the placement of accent. Natural Language Semantics 7(2). 141-177. http: //dx.doi.org/10.1023/A:1008370902407.

Seiffe, Laura. 2013. Scrambling und Akzentverschiebung in deutschen Nebensätzen. Bachelor's thesis, University of Potsdam.

Šimík, Radek, Marta Wierzba \& Beste Kamali. 2014. Givenness and the position of the direct object in the Czech clause. Formal Approaches to Slavic Linguistics (FASL) 22. 302-318.

Slioussar, Natalia. 2007. Grammar and information structure: A study with reference to Russian. Utrecht University $\mathrm{PhD}$ thesis. http://www.lotpublications. $\mathrm{nl} /$ index3.html.

Szendröi, Kriszta. 2001. Focus and the syntax-phonology interface. University College London PhD thesis.

Szendröi, Kriszta. 2003. A stress-based approach to the syntax of Hungarian focus. The Linguistic Review 20(1). 37-78. http://dx.doi.org/10.1515/tlir. 2003.002.

Taglicht, J. 1982. Intonation and the assessment of information. Journal of Linguistics 18(2). 213-230. http://dx.doi.org/10.1017/Soo2222670001358X. 
Šimík \& Wierzba

Titov, Elena. 2012. Information structure of argument order alternations. University College London PhD thesis.

Truckenbrodt, Hubert. 1995. Phonological phrases: Their relation to syntax, focus, and prominence. Cambridge, MA: Massachusetts Institute of Technology $\mathrm{PhD}$ thesis.

Truckenbrodt, Hubert. 2012. On the prosody of German wh-questions. In Gorka Elordieta \& Pilar Prieto (eds.), Prosody and meaning, 73-117. Berlin \& Boston, MA: de Gruyter.

Veselovská, Ludmila. 1995. Phrasal movement and $X^{0}$ morphology: Word order parallels in Czech and English nominal and verbal projections. Olomouc: Palacký University PhD thesis.

Wagner, Michael. 2006. Givenness and locality. Semantics and Linguistic Theory (SALT) 16. 295-312.

Wagner, Michael. 2012. Focus and givenness: A unified approach. In Ivona Kučerová \& Ad Neeleman (eds.), Contrasts and positions in information structure, 102-147. Cambridge: Cambridge University Press.

Witkoś, Jacek. 2007. Polish and the A-type scrambling. Formal Description of Slavic Languages (FDSL) 6. 165-180.

Zubizarreta, Maria Luisa. 1998. Prosody, focus, and word order. Cambridge, MA: MIT Press.

Radek Šimík

University of Potsdam

Linguistics Department/SFB632

Karl-Liebknecht-Straße 24-25

14476 Potsdam

Germany

simik@uni-potsdam.de

\author{
Marta Wierzba \\ University of Potsdam \\ Linguistics Department/SFB632 \\ Karl-Liebknecht-Straße 24-25 \\ 14476 Potsdam \\ Germany \\ wierzba@uni-potsdam.de
}

\section{A Instructions for the participants}

The instructions to the participants were presented in the form of a written text that appeared on the monitor (each participant was seated at a different computer) immediately before the onset of the experiment. The instructions appeared on three subsequent screens and each participant could decide to move on to the next screen by pressing SPACE - giving everybody as much time as they needed to read the instructions. The instructions included three example items (see B.1) which were designed to help the participants to conceptualize the notion of "acceptability". They included one clearly acceptable utterance (predicted to be acceptable by all relevant theories) and two clearly unacceptable utterances (predicted 
The role of givenness, presupposition, and prosody in Czech word order

to be unacceptable by all relevant theories). The participants had the choice to listen to the examples once or twice. Naturally, the instructions were written in Czech. Below, I provide an English translation.

\section{First screen}

During this experiment your task will be to evaluate the acceptability of utterances in a particular context. You will listen to 126 short dialogs, one-by-one. These dialogs function in isolation, that is, one dialog does not have any relation to another. Every dialog consists of an utterance of a woman and a subsequent utterance of a man. Sometimes it is a questionanswer pair, other times it is a different kind of dialog.

Your task will be to evaluate the acceptability of the man's utterance in the context of the woman's utterance. The evaluation proceeds on a scale from 1 (completely unacceptable utterance/reaction) to 9 (completely acceptable utterance/reaction). Be careful - your evaluation always only targets the man's utterance, the woman's utterance only serves as a context and your evaluation does not target it.

\section{Second screen}

For your idea of what we mean by acceptability, we will play three example dialogs for you. In the first one the man's utterance as a reaction to the woman's utterance is acceptable (evaluation roughly 7,8 , or 9 ) and in the next two it is unacceptable (roughly 1, 2, or 3). [After each example dialog, the participant was reminded of the acceptability status.]

\section{Third screen}

The experiment will proceed as follows. You will hear a dialog, after which a numerical scale from 1 to 9 (a completely unacceptable utterance to a completely acceptable utterance) appears. At that point, press the key that corresponds to your evaluation of the acceptability of the man's utterance. By pressing SPACE you proceed to the next dialog. Some warnings before you start: You will hear every dialog only once. It is impossible to get back to previous dialogs. Likewise, it is impossible to change your previous evaluations. In case you fail to hear the dialog properly or if you make a mistake in your evaluation, there is nothing to be done, you should simply proceed with the experiment. Please, behave silently during the experiment, so that you do not disturb other participants.

\section{B Items}

This appendix contains all the experimental items in a written form. (The actual items were presented auditorily.) Sentence stress is marked by capitals. In experiment 1 (B.3), definite contexts are in (ai) and indefinite ones are in (aii).

\section{B.1 Example items}

(1) a. Nevíš, na čem dnes večer dávají ten tenis? NEG.know.2SG on what today evening give.3PL the tennis 
'Do you know which channel is showing the tennis tonight?'

b. Podle mě dávají ten tenis NA NOVĚ.

according me give.3PL the tennis on Nova

'In my opinion the Nova channel is showing the tennis.'

(2) a. Nevíš, na čem dnes večer dávají ten tenis?

NEG.know.2SG on what today evening give.3PL the tennis

'Do you know which channel is showing the tennis tonight?'

b. Podle mě dávají ten TENIS na Nově.

according me give.3PL the tennis on Nova

'In my opinion the Nova channel is showing the tennis.'

(3) a. Nevíš, na čem dnes večer dávají ten tenis?

NEG.know.2SG on what today evening give.3PL the tennis

'Do you know which channel is showing the tennis tonight?'

b. Podle mě ten tenis NA NOVĚ dávají.

according me the tennis on Nova give.3PL

'In my opinion the Nova channel is showing the tennis.'

\section{B.2 Training items}

(1) a. Pozval jsem toho tvého kamaráda zítra na večeři. Nevíš, jestli je invited be.1SG that your friend tomorrow on dinner NEG.know.2SG if be.3SG něco, co vyloženě nemá rád?

something that really NEG.have.3SG glad

'I invited that friend of yours for dinner tomorrow. Do you kow if there is something he really doesn't like?'

b. Myslím, že nemá rád ŠPENÁT.

think.1SG that NEG.have.3SG glad spinach

'I think he doesn't like spinach.'

(2) a. Když jsem se potkali minule, hledal jsi nějaký dárek pro svou when be.1SG REFL met last.time looked.for be.2SG some present for your matku. Cos jí vlastně koupil? mother what-be.2SG her actually bought

'Last time we met you were looking for a present for your mother. What did you buy for her?'

b. Byl to těžký výběr, ale nakonec jsem jí koupil stříbrné NÁUŠNICE. was it difficult choice but finally be.1SG her bought silver earrings 'It was hard to choose but in the end I bought silver earrings.'

(3) a. Jé, taky bych brala dva týdny volna. Jak chceš to volno využít? oh also would.1SG took two weeks off how want.2SG the days.off use 'Oh, I would love to have two weeks off. How are you going to spend it?'

b. Přihlásil jsem se do intenzivního kurzu ŠPANĚLŠTINY. enrolled be.1SG REFL in intensive course spanish 'I enrolled on an intensive Spanish course.' 
The role of givenness, presupposition, and prosody in Czech word order

(4) a. Takže tento víkend budeš trávit se synem? Už máte nějaký plán? so this weekend will.2SG spend with son already have.2PL some plan 'So, will you spend this weekend with your son? Do you have any plans already?'

b. Jo, chtěl bych SYNA vzít do zoo.

yes wanted would.isG son take to zoo

'Yes I'd like to take my son to the zoo.'

(5) a. Komus prosím tě půjčil tu sekačku na trávu?

whom-be.2SG please.1SG you lent that mower on lawn

'Who did you lend the lawnmower, please?'

b. Půjčil jsem Karlovi tu sekačku NA TRÁVU.

lent be.1SG Karel the mower on lawn

'I lent that lawnmower to Karel.'

(6) a. Nevíš náhodou, co Marie studovala?

NEG.know.2SG by.chance what Marie studied

'By chance do you know what Marie studied?'

b. MARIE studovala fyziku.

Marie studied physics

'Marie studied physics.'

\section{B.3 Experiment 1}

(1) a. (i) Jak bylo na dovolené? Karel se tak těšil, že uvidí zámek v how was on holiday Karel REFL so looked.forward that see.pf castle in Hluboké.

Hluboká

'How was the holiday? Karel was looking forward to seeing the Hluboká Castle so much.'

(ii) Jak bylo na dovolené? Před odjezdem mi Karel říkal, že ještě nikdy how was on holiday before departure me Karel said that still never.NCI neviděl žádný zámek.

NEG.saw no.NCI castle

'How was the holiday? Before the departure, Karel told me that he had never seen any castle.'

b. (i) Kvůli němu jsme nakonec zámek NAVŠTívILI.

because.of him AUX.1PL in.the.end castle visited

'In the end we visited the/a castle because of him.'

(ii) Kvůli němu jsme nakonec ZÁMEK navštívili.

(iii) Kvůli němu jsme nakonec navštívili ZÁMEK.

(iv) Kvůli němu jsme nakonec NAVŠTívILI zámek. 
(2) a. (i) Jak bylo včera $\mathrm{v}$ lese? Slyšel jsem, že jste měli na mušce how was yesterday in forest heard be.1SG that be.2PL had on front.sight nádherného jelena.

beautiful deer 'How was the forest yesterday? I heard that you were aiming at a beautiful deer.'

(ii) Jak bylo včera $\mathrm{v}$ lese? Slyšel jsem, že se přemnožili how was yesterday in forest heard be.1SG that REFL reproduced.excessively jeleni.

deer

'How was the forest yesterday? I heard that deer reproduced excessively.'

b. (i) Máš pravdu, ale bohužel jsme jelena NEULOVILI. have.2SG truth but unfortunately be.1PL deer NEG.shot 'You're right but unfortunately we didn't kill the/a deer.'

(ii) Máš pravdu, ale bohužel jsme JELENA neulovili.

(iii) Máš pravdu, ale bohužel jsme neulovili JELENA.

(iv) Máš pravdu, ale bohužel jsme NEULOVILI jelena.

(3) a. (i) To je zvláštní, najednou zmizely všechny sekretářky. it be.3SG strange suddenly disappeared all secretaries That's strange, all of a sudden all secretaries disappeared.

(ii) Slyšel jsem, že je dnes nouze o dobré sekretářky. heard be.1SG that be.3SG today shortage about skillfull secretaries 'I heard there is a shortage of skillfull secretaries.'

b. (i) Máš pravdu, na katedře biologie pořád ještě sekretářku HLEDAJí. have.2SG truth at department biology always still secretary look.for.3PL 'You're right, at the biology department they're still looking for the/a secretary.'

(ii) Máš pravdu, na katedře biologie pořád ještě SEKRETÁŘKU hledají.

(iii) Máš pravdu, na katedře biologie pořád ještě hledají SEKRETÁŘKU.

(iv) Máš pravdu, na katedře biologie pořád ještě HLEDAJí sekretářku.

(4) a. (i) Co budeme zítra jíst? Vidím, že $v$ ledničce je ještě jeden what will.1PL tomorrow eat see.1SG that in fridge be.3SG still one losos.

salmon

'What are we going to eat tomorrow? I can see that there is one more piece of salmon in the fridge.'

(ii) Na trhu prý mají čerstvé lososy. at market reportedly have.3PL fresh salmon 'Reportedly they have fresh salmon at the market'

b. (i) Tak to bychom zítra mohli lososa POOBĚDVAT. so it would.1PL tomorrow could salmon have.for.lunch 'So tomorrow we could have the/a salmon for lunch.'

(ii) Tak to bychom zítra mohli LOSOSA poobědvat.

(iii) Tak to bychom zítra mohli poobědvat LOSOSA.

(iv) Tak to bychom zítra mohli POOBĚDVAT lososa. 
The role of givenness, presupposition, and prosody in Czech word order

(5) a. (i) Všiml sis už, že soused si pořídil novou kočku? noticed refl-be.2SG already that neighbour REFL got new cat 'Have you noticed that our neighbour has got himself a new cat?'

(ii) Měla jsem za to, že náš soused nemá rád kočky, ale asi had be.1SG for it that our neighbour NEG.have.3SG glad cats but maybe jsem se mýlila.

be.1SG REFL was.wrong 'I thought that our neighbour doesn't like cats but maybe I was wrong.'

b. (i) Jo, včera $\mathrm{z}$ balkónu kočku PŘIVOLÁVAL. yes yesterday from balcony cat called 'Yes, yesterday he was calling the/a cat from his balcony.'

(ii) Jo, včera $\mathrm{z}$ balkónu KOČKU přivolával.

(iii) Jo, včera z balkónu přivolával KOČKU.

(iv) Jo, včera z balkónu PřIVOLÁVAL kočku.

(6) a. (i) Pořád jsem ještě nepřečetl tu tlustou knížku do literárního semináře. still be.1SG yet NEG.read that thick book for literary seminar 'I still haven't finished that thick book for literary seminar.'

(ii) Už mě začíná štvát, že tu nemám co číst. Nevím, already me start.3SG annoy that here NEG.have.1SG what read NEG.know.1SG proč jsem si s sebou nevzala žádnou knížku. why be.1SG REFL with myself NEG.took any book 'It starts to annoy me that I haven't got anything to read. I don't know why I didn't bring a book.'

b. (i) Jsem na tom stejně, zítra asi konečně zajdu do knihovny be.1SG on that the.same.way tomorrow maybe finally go.1SG to library

a knížku si VYPŮJČím. and book REFL borrow.1SG 'It's the same for me; tomorrow I'll go to the library and borrow the/a book.'

(ii) Jsem na tom stejně, zítra asi konečně zajdu do knihovny a KNÍŽKU si vypůjčím.

(iii) Jsem na tom stejně, zítra asi konečně zajdu do knihovny a vypůjčím si KNÍŽKU.

(iv) Jsem na tom stejně, zítra asi konečně zajdu do knihovny a VYPƯJČím si knížku.

(7) a. (i) Jedním z cílů této hry je mít na konci hry tento zlatý poklad. one of goals this game be.3SG have at end game this golden treasure 'One of the goals of this game is to have this golden treasure by the end of the game.'

(ii) Jedním z cílů této hry je mít na konci hry aspoň tři poklady. one of goals this game be.3SG have at end game at.least three treasures 'One of the goals of this game is to have at least three golden treasures by the end of the game.'

b. (i) Výborně, já už jsem poklad OBJEVIL. great I already be.1sG treasure discovered 'Great, I've already discovered the/a treasure.'

(ii) Výborně, já už jsem POKLAD objevil.

(iii) Výborně, já už jsem objevil POKLAD.

(iv) Výborně, já už jsem OBJEVIL poklad. 
(8) a. (i) Vzpomínáš si na toho doktora? Nevíš, jestli bude i na remember.2SG REFL on that doctor NEG.know.2SG if will.be.3SG even at té akci?

that event

'Do you remember that doctor? Do you know if he's going to be at that event?'

(ii) Nevíš, jestli bude na té akci nějaký doktor?

NEG.know.2SG if will.be.3SG at that event any doctor

'Do you know if there is going to be a doctor at that event?'

b. (i) Jo, podle mě doktora POZVALI.

yes according me doctor invited

'Yes, I think they invited the/a doctor.'

(ii) Jo, podle mě DOKTORA pozvali.

(iii) Jo, podle mě pozvali DOKTORA.

(iv) Jo, podle mě POZVALI doktora.

(9) a. (i) Zajímalo by mě, proč fitness centrum v našem městě musí být interested would.3SG me if fitness centre in our city must.3sg be v tak hrozném stavu.

in such horrible state

'I wonder why the fitness centre in our city has to be in such a horrible state.'

(ii) Škoda, že u nás ve městě nikdy nebylo fitness centrum.

pity that by us in town never NEG.was fitness centre

'It's a pity that there has never been a fitness centre in our city.'

b. (i) Náš ředitel prý jednou fitness centrum PROVOZOVAL. our director they.say once fitness centre ran

'They say that our director once ran the/a fitness centre.'

(ii) Náš ředitel prý jednou FITNESS centrum provozoval.

(iii) Náš ředitel prý jednou provozoval FITNESS centrum.

(iv) Náš ředitel prý jednou PROVOZOVAL fitness centrum.

(10) a. (i) Víš, že Američané nasadili do Iráku na jednoho afgánského know.2SG that americans deployed in Iraq on one afghan teroristu zvláštní komando?

terrorist special commando

'Do you know that Americans have deployed a special commando for one Afghan terrorist in Iraq?'

(ii) Víš, že Američané nasadili do Iráku na teroristy zvláštní

know.2SG that americans deployed in Iraq on terrorists special

komando?

commando

'Do you know that Americans have deployed a special terrorist commando in Iraq?' 
The role of givenness, presupposition, and prosody in Czech word order

b. (i) Jo, už před rokem, ovšem ještě teroristu NEVYPÁTRALI. yes already before year though yet terrorist NEG.tracked.down 'Yes, already a year ago but they still haven't tracked down the/a terrorist.'

(ii) Jo, už před rokem, ovšem ještě TERORISTU nevypátrali.

(iii) Jo, už před rokem, ovšem ještě nevypátrali TERORISTU.

(iv) Jo, už před rokem, ovšem ještě NEVYPÁTRALI teroristu.

(11) a. (i) To video myslím můžeš zastavit použitím tlačítka escape. this video think.1SG can.2SG stop using button escape 'I think you can stop the video by using the escape button.'

(ii) To video myslím můžeš zastavit použitím jakéhokoliv tlačítka. this video think.1SG can.2SG stop using any button 'I think you can stop the video by using any button.'

b. (i) To právě nejde, už jsem tlačítko STISKNUL. that just NEG.work.3SG already be.1SG button pressed 'Only it's not working, I've already pressed the/a button.'

(ii) To právě nejde, už jsem TLAČÍTKO stisknul.

(iii) To právě nejde, už jsem stisknul TLAČÍTKO.

(iv) To právě nejde, už jsem STISKNUL tlačítko.

(12) a. (i) Doufám, žes včera večer nehladověl, ta jediná hope.1SG that-be.2SG yesterday evening NEG.was.hungry the only večerka $\quad \mathrm{v}$ okolí je dost dobře ukrytá. convenience.store in neighbourhood be.3SG rather well hidden 'I hope you weren't starving again last night; the only convenience store in the neighbourhood is rather well hidden.'

(ii) Doufám, žes včera večer nehladověl, není tady v hope.1SG that-be.2SG yesterday evening NEG.was.hungry NEG.be.3SG here in okolí bohužel moc večerek. neighbourhood unfortunately many convenience.stores 'I hope you weren't starving last night; there aren't many convenience stores in the neighbourhood.'

b. (i) No, měl jsem štěstí, nakonec jsem večerku NAŠEL. well had be.1SG luck eventually be.1SG convenience.store found 'Well, I was lucky, eventually I found the/a conveniece store.'

(ii) No, měl jsem štěstí, nakonec jsem VEČERKU našel.

(iii) No, měl jsem štěstí, nakonec jsem našel VEČERKU.

(iv) No, měl jsem štěstí, nakonec jsem NAŠEL večerku. 
(13) a. (i) Petr je hrozný romantik. Když chystal tu večeři s Marií, Petr be.3SG terrible romantic.person when prepared the dinner with Marie byla dokonce řeč o jedné vzácné svíčce, kterou nedávno was even conversation about one unique candle which recently koupil. bought 'Petr is a terribly romantic person. When he was preparing the dinner with Marie, there was even a talk about a unique candle he had recently bought.'

(ii) Petr je hrozný romantik. Když chystal tu večeři s Marií, Petr be.3SG terrible romantic.person when prepared the dinner with Marie byla dokonce řeč o svíčkách.

was even conversation about candles

'Petr is a terribly romantic person. When he was preparing the dinner with Marie, there was even a talk about candles.'

b. (i) Jo, mám pocit, že opravdu při večeři svíčku ZAPÁLIL. yes have.1SG feeling that really during dinner candle lit 'Yes, I think that he really lit the/a candle during the dinner.'

(ii) Jo, mám pocit, že opravdu při večeři SVÍČKU zapálil.

(iii) Jo, mám pocit, že opravdu při večeři zapálil SVÍČKU.

(iv) Jo, mám pocit, že opravdu při večeři ZAPÁLIL svíčku.

(14) a. (i) Zdeňkův nový byt je hezký, ale jde mu pořád ještě Zdeněk.poss new flat be.3SG nice but be.possible.3SG him always still vidět z ulice do oken. Nedávno mi ale říkal, že konečně našel see from street to windows not.long.ago me but told that finally found ten pravý závěs. the right curtain 'Zdeněk's new flat is nice but people walking on the street can still see through his windows. However, not long ago, he told me that he finally found the right curtain.'

(ii) Zdeňkův nový byt je hezký, ale jde mu pořád ještě Zdeněk.poss new flat be.3SG nice but be.possible.3sG him always still vidět z ulice do oken. Prý v obchodech nemají žádné see from street to windows they.say in shops NEG.have.3PL any dobré závěsy. favourable curtains

'Zdeněk's new flat is nice but people walking on the street can still see through his windows. They say that there aren't any favourable curtains in shops.'

b. (i) Slyšel jsem, že si zrovna včera závěs POŘíDIL. heard be.1SG that REFL just yesterday curtain got 'I heard he just bought the/a curtain yesterday.'

(ii) Slyšel jsem, že si zrovna včera ZÁVĚS pořídil.

(iii) Slyšel jsem, že si zrovna včera pořídil ZÁVĚS.

(iv) Slyšel jsem, že si zrovna včera POŘíDIL závěs. 
The role of givenness, presupposition, and prosody in Czech word order

(15) a. (i) Je pravda, že se váš syn poté co jste byli v zoo úplně be.3SG truth that REFL your son after what be.2PL was in zoo totally zbláznil do toho čerstvě narozeného slona?

fell for the newly born elephant

'Is it true that after visiting the zoo your son totally fell for the newly born elephant?'

(ii) Je pravda, že se váš syn úplně zbláznil do slonư?

be.3SG truth that REFL your son totally fell for elephants

'Is it true that your son totally fell for elephants?'

b. (i) Jo, to je fakt, včera ve školce prý slona yes it be.3SG fact yesterday in kindergarden they.say elephant NAMALOVAL.

drew

'Yes, that's true, just yesterday he drew the/an elephant in the kindergarden, they say.'

(ii) Jo, to je fakt, včera ve školce prý SLONA namaloval.

(iii) Jo, to je fakt, včera ve školce prý namaloval SLONA.

(iv) Jo, to je fakt, včera ve školce prý NAMALOVAL slona.

(16) a. (i) Jak se daří Lenčině vzácné pokojové rostlině? Má how REFL be.doing.3SG Lenka.poss rare indoor plant have.3SG ještě pořád ten krásný obrovský list? always still the marvellously gigantic leaf 'How is Lenka's rare indoor plant doing? Has it still got that marvellously gigantic leaf?'

(ii) Jak vidím, Lenčina vzácná pokojová rostlina trochu strádá, má as see.1SG Lenka.poss rare indoor plant a.little wither.3SG have.3SG vůbec ještě všechny listy? actually still all leaves 'I can see that Lenka's rare indoor plant is withering a little, has it still got all leaves?'

b. (i) Pokud vím, nedávno už list ZTRATILA. as.far.as know.1SG recently already leaf lost 'As far as I know, it has recently lost the/a leaf.'

(ii) Pokud vím, nedávno už LIST ztratila.

(iii) Pokud vím, nedávno už ztratila LIST.

(iv) Pokud vím, nedávno už ZTRATILA list. 
(17) a. (i) Honzík už je pryč? Určitě si tady zase zapomněl ten rohlík, co Honzík already be.3SG away surely REFL here again forgot the roll that jsem mu nachystala.

be.1SG him prepared

'Has Honzík already gone? For sure, he has again forgotten that roll I prepared for him.'

(ii) Honzík si určitě zase zapomněl vzít do školy něco na jídlo. Honzík REFL surely again forgot take to school something to eat

Neměl by si aspoň koupit rohlík?

NEG.should would.3SG REFL at.least buy roll

'For sure, Honzík has again forgotten to take something to eat to school. Shouldn't he buy a roll at least?'

b. (i) Žádný strach, když odcházel, viděl jsem, jak si rohlík BERE.

no fear when left saw be.1SG how REFL roll take.3SG

'Don't worry, when he was leaving I saw him taking the/a roll.'

(ii) Žádný strach, když odcházel, viděl jsem, jak si ROHLÍK bere.

(iii) Žádný strach, když odcházel, viděl jsem, jak si bere ROHLíK.

(iv) Žádný strach, když odcházel, viděl jsem, jak si BERE rohlík.

(18) a. (i) Slyšel jsem o jedné nové počítačové hře, která je prý heard be.1SG about one new computer game which be.3SG they.say obzvlášt' brutální. Snad jste ji nekoupili Martinovi na Vánoce? especially brutal hopefully be.2PL it NEG.bought Martin for Christmas 'I have heard about a new computer game which is particularly brutal, they say. I hope you didn't buy Martin one for Christmas.'

(ii) Nezdá se vám, že Martin už má těch počítačových NEG.seem.3SG REFL you that Martin already have.3SG those computer her trošku moc? Snad jste mu na Vánoce nekoupili games a.little.bit many hopefully be.2PL him for Christmas NEG.bought další? another 'Don't you think Martin has got way too many computer games? I hope you didn't buy him another one for Christmas?'

b. (i) My ne, ale přesto na Vánoce Martin hru DOSTAL. we not but yet for Christmas Martin game got 'Not us and yet Martin got the/a game for Christmas.'

(ii) My ne, ale přesto na Vánoce Martin HRU dostal.

(iii) My ne, ale přesto na Vánoce Martin dostal HRU.

(iv) My ne, ale presto na Vánoce Martin DOSTAL hru. 
The role of givenness, presupposition, and prosody in Czech word order

(19) a. (i) Nedávno tu vlastně byl cirkus s tím slavným klaunem. Jaký byl not.long.ago here actually was circus with the famous clown how was a jak se líbil dětem?

and how REFL liked kids

'Not long ago actually, there was this circus with the famous clown. How was he and how did the kids like him?'

(ii) Tak jak bylo $\mathrm{s}$ dětma $\mathrm{v}$ cirkuse? Měli tam i nějaké klauny? so how was with kids in circus had there even some clowns 'So, how was the circus with kids? Were there any clowns?'

b. (i) Bohužel jsem nakonec nešel, ale vzpomínám si, že se unfortunately be.1SG eventually NEG.went but remember.1SG REFL that REFL děti nemohly klauna DOČKAT.

kids NEG.could clown wait.to.see 'Unfortunately, I didn't go in the end but I remember that the kids couldn't wait to see the/a clown.'

(ii) Bohužel jsem nakonec nešel, ale vzpomínám si, že se děti nemohly KLAUNA dočkat.

(iii) Bohužel jsem nakonec nešel, ale vzpomínám si, že se děti nemohly dočkat KLAUNA.

(iv) Bohužel jsem nakonec nešel, ale vzpomínám si, že se děti nemohly DOČKAT klauna.

(20) a. (i) Mám problém, nutně si dnes musím obléct košili, ale uvědomil have.1SG problem urgently REFL today must.1SG put.on shirt but realized jsem si, že moje jediná košile není čistá! be.1SG REFL that my only shirt NEG.be.3SG clean 'I've got a problem, I really need to put on a shirt but I realized that I haven't got a single clean shirt!'

(ii) Dneska si nutně musím obléct košili, ale jak se tak dívám, today REFL urgently must.1SG put.on shirt but how REFL so see.1SG nemám už žádnou čistou!

NEG.have.1SG any clean

'I really need to put on a shirt today but I can see I haven't got a single clean one!'

b. (i) Žádný strach, včera jsem ti košili VYPRAL.

no fear yesterday be.1SG you shirt washed

'Don't worry, I washed the/a shirt for you yesterday.'

(ii) Žádný strach, včera jsem ti KOŠILI vypral.

(iii) Žádný strach, včera jsem ti vypral KOŠILI.

(iv) Žádný strach, včera jsem ti VYPRAL košili. 
(21) a. (i) Už jsme s přípravami skoro hotoví, chybí nám jen ta already be.1PL with preparations almost finished miss.3SG us only the dekorovaná židle. decorated chair 'We're nearly done with the preparations, the only thing left to do is that decorated chair.'

(ii) Už jsme s př́pravami skoro hotoví, chybějí nám už already be.1PL with preparations almost finished miss.3PL us already jenom nějaké židle. only some chairs 'We're nearly done with the preparations, the only thing left to do are some chairs.'

b. (i) $\mathrm{Z}$ vedlejšího pokoje vám můžu židli PŘINÉST. from neighbouring room you can.1SG chair bring 'I can bring a chair from the/a neighbouring room.'

(ii) Z vedlejšího pokoje vám můžu ŽIDLI přinést.

(iii) Z vedlejšího pokoje vám můžu přinést ŽIDLI.

(iv) Z vedlejšího pokoje vám můžu PŘINÉST židli.

(22) a. (i) U sousedů na farmě je pozdvižení - utekla jim jejich jediná at neighbours on farm be.3SG fuss ran.away them their only kráva. Už hodiny ji bezúspěšně hledají. cow already hours her unsuccessfully look.for.3PL 'There has been a lot of fuss at the neighbours' farm - their only cow has run away. They have been looking for her for hours but without success.'

(ii) Na naší farmě chováme hlavně drůbež a menší hospodářská zvířata. on our farm keep.1PL mainly poultry and smaller farm animals Od minulého roku už nemáme žádné krávy. since last year already NEG.have.1PL any cows 'We keep mainly poultry and smaller farm animals at our farm. Since the last year we haven't got cows anymore.'

b. (i) To je zvláštní, mám pocit, že jsem před chvílí krávu VIDĚL. it be.3SG strange have.1SG feeling that be.1SG before while cow saw 'That's strange; I thought I saw the/a cow just a while ago.'

(ii) To je zvláštní, mám pocit, že jsem před chvílí KRÁVU viděl.

(iii) To je zvláštní, mám pocit, že jsem před chvílí viděl KRÁVU.

(iv) To je zvláštní, mám pocit, že jsem před chvílí VIDĚL krávu.

(23) a. (i) Jitka ztratila svioj sešit. Neviděl jsi ho někde? Jitka lost her exercise.book NEG.saw be.2SG it somewhere 'Jitka has lost her exercise book. Have you seen it somewhere?'

(ii) Právě jsem zjistila, že nám došly sešity. Ted' nemáme just be.1SG found.out that us ran.out.of exercise.books now NEG.have.1PL do čeho zapisovat výsledky.

to what write.down results

'I've just found out that we ran out of exercise books. We've got nothing to write the results in.' 
The role of givenness, presupposition, and prosody in Czech word order

b. (i) Počkej, podívám se, jestli náhodou sešit NEMÁM.

wait look.1SG REFL if accidentally exercise.book NEG.have.1SG

'Wait, I'll take a look, maybe I've got the/an exercise book.'

(ii) Počkej, podívám se, jestli náhodou SEŠIT nemám.

(iii) Počkej, podívám se, jestli náhodou nemám SEŠIT.

(iv) Počkej, podívám se, jestli náhodou NEMÁM sešit.

(24) a. (i) Zvláštní, včera jsem natrhala nějaké sněženky a ted' je strange yesterday be.1SG picked some snowdrops and now them nemůžu najít.

NEG.can.1SG find

'Strange, just yesterday I picked some snowdrops but I can't find them now.'

(ii) Zvláštní, jaro je skoro tady, a stejně jako poslední tři roky strange spring be.3SG almost here and still as last three years jsem nenarazila na žádnou sněženku. be.1SG NEG.came across any snowdrop 'Strange, spring is coming and just as in the last three years I haven't come across any snowdrops.'

b. (i) Fakt? Mirek prý někde sněženky ZAHLÉDL. really Mirek they.say somewhere snowdrops saw 'Really? I hear Mirek has seen the/some snowdrops somewhere.'

(ii) Fakt? Mirek prý někde SNĚŽENKY zahlédl.

(iii) Fakt? Mirek prý někde zahlédl SNĚŽENKY.

(iv) Fakt? Mirek prý někde ZAHLÉDL sněženky.

(25) a. (i) Slyšel jsi, že Kubík dnes na pouti vyhrál krásného plyšáka? heard be.2SG that Kubík today at funfair won gorgeous stuffed.animal 'Did you hear that today Kubík won a gorgeous stuffed animal at the funfair?'

(ii) Na pouti se prý dnes dali vyhrát krásní plyšáci. Měl at funfair REFL they.say today could win gorgeous stuffed.animals had Kubík taky štěstí?

Kubík also luck

'They say you could win gorgeous stuffed animals at the funfair today. Was Kubík also lucky?'

b. (i) Jo, viděl jsem, jak si plyšáka NESE.

yes saw be.1SG how REFL stuffed.animal carry.3SG

'Yes, I've seen him carrying the/a stuffed animal.'

(ii) Jo, viděl jsem, jak si PLYŠÁKA nese.

(iii) Jo, viděl jsem, jak si nese PLYŠÁKA.

(iv) Jo, viděl jsem, jak si NESE plyšáka. 
(26) a. (i) Nechápu, proč tu tento policista tak postává, když na NEG.understand.1SG why here this policeman so stand.3SG while at vedlejším náměstí potřebují posily.

next square need.3PL backup

'I don't understand why that policeman is still hanging around while at the next square they need backup.'

(ii) To je neuvěřitelné, už je to půl hodiny a na místě činu it be.3SG unbelievable already be.3SG it half hour and at crime scene pořád ještě není ani jeden policista. always still NEG.be.3SG not.even one policeman 'It's unbelievable, it's been already half an hour and at the crime scene there isn't even a single policeman.'

b. (i) Dobře, okamžitě tam policistu POŠLEME.

ok immediately there policeman send.ıPL

'Alright, we're sending the/a policeman immediately.'

(ii) Dobře, okamžitě tam POLICISTU pošleme.

(iii) Dobře, okamžitě tam pošleme POLICISTU.

(iv) Dobře, okamžitě tam POŠLEME policistu.

(27) a. (i) Před nějakou dobou Karel tvrdil, že každému namaluje originální before some time Karel claimed that everyone paint.3SG authentic obraz. Nejspíš z toho ale sešlo.

painting probably from that but went.off

'Some time ago Karel said that he was going to paint an authentic picture for everyone. But I guess it went off.'

(ii) Karel je všestranný umělec, ovšem klasické obrazy ho nikdy moc Karel be.3SG versatile artist though classical painting him never much nezajímaly.

NEG.interested

'Karel is a versatile artist but classical paintings has never been of any interest to him.'

b. (i) Mně ale dnes ř́ikal, že mi obraz NAMALUJE. me but today said that me painting paint.3SG

'But he told me today that he's going to paint the/a picture for me.'

(ii) Mně ale dnes říkal, že mi OBRAZ namaluje.

(iii) Mně ale dnes říkal, že mi namaluje OBRAZ.

(iv) Mně ale dnes říkal, že mi NAMALUJE obraz. 
The role of givenness, presupposition, and prosody in Czech word order

(28) a. (i) Ty máš ale krásnou propisku, ta by se mi hodila you have.2SG such lovely biro that would.3SG REFL me came.in.handy k podepisování té nové smlouvy. for signing that new contract 'You've got such a lovely biro; it would come in handy for signing that new contract.'

(ii) Nechápu proč, ale pořád ztrácím propisky. Už zase

NEG.undestand.1SG why but still lose.1SG biros yet again

nemám čím psát.

NEG.have.1SG by.it write

'I don't get why I keep loosing biros all the time. I've got nothing to write with again.'

b. (i) Jestli chceš, můžu ti propisku PUீJČIT.

if want.2SG can.1SG you biro lend

'If you want I can lend you the/a biro.'

(ii) Jestli chceš, můžu ti PROPISKU půjčit.

(iii) Jestli chceš, můžu ti půjčit PROPISKU.

(iv) Jestli chceš, můžu ti PƯJČIT propisku.

(29) a. (i) Tak co Táňa, zkoušela už ty svoje nové brusle?

so what Tán̆a tried already the her new skates

'So what about Táňa, has she already tried her new skates?'

(ii) Naši dceru vždycky strašně bavilo jezdit na bruslích. Co Táňa, už our daughter always terribly liked ride on skates what Táňa already to někdy zkoušela?

it ever tried

'Our daughter always really liked skating. What about Táňa, has she ever tried that?'

b. (i) Zkoušela, ale jenom jednou, potom totiž někde brusle ZTRATILA.

tried but only once then actually somewhere skates lost

'She has, but only once; then she actually lost the/some skates somewhere.'

(ii) Zkoušela, ale jenom jednou, potom totiž někde BRUSLE ztratila.

(iii) Zkoušela, ale jenom jednou, potom totiž někde ztratila BRUSLE.

(iv) Zkoušela, ale jenom jednou, potom totiž někde ZTRATILA brusle.

(30) a. (i) Při mém posledním letu se událo malé drama. Nemohli jsme during my last flight REFL happened little drama NEG.could be.1PL vzlétnout, protože jedna letuška zapomněla nastoupit do služby. take.off because one flight.attendant forgot appear for shift 'During my last flight there had been a little drama. We couldn't take off because one flight attendant didn't appear for her shift.'

(ii) Při mém posledním letu se událo malé drama. Nějaká stará paní during my last flight REFL happened little drama some old lady se začala dusit a najednou nebyla $\mathrm{k}$ nalezení ani jedna REFL started choke and suddenly NEG.was to find not.even one letuška.

flight.attendant 
'During my last flight there had been a little drama. An old woman started choking and suddenly no flight attendant was to be found.'

b. (i) A podařilo se nakonec letušku ZAVOLAT?

and managed REFL eventually flight.attendant called

'Did they eventually manage to call the/a flight attendant?'

(ii) A podařilo se nakonec LETUŠKU zavolat?

(iii) A podařilo se nakonec zavolat LETUŠKU?

(iv) A podařilo se nakonec ZAVOLAT letušku?

(31) a. (i) Ty máš prý ten nový automatický vysavač. Funguje dobře you have.2SG they.say the new automatic vaccum.cleaner work.3SG well

i ted', co ses prestěhoval - tvůj nový byt je dost členitý. even now when be.2SG-refl moved your new flat be.3SG very divided 'I heard you have that new automatic vacuum cleaner. Does it work properly even now when you moved - your new flat has many sections.'

(ii) Bavili jsme se $\mathrm{s}$ Jarkem o tom, jestli vysavač nemůže talked be.1PL REFL with Jarek about it if vacuum.cleaner NEG.can.3SG uškodit parketám.

harm parquet.floor

'We were talking with Jarek about whether the vacuum cleaner can possibly do some harm to the parquet floor.'

b. (i) No, já jsem $\mathrm{v}$ novém bytě ještě vysavač NEPOUŽIL.

well I be.1SG in new flat yet vacuum.cleaner NEG.used

'Well, I haven't used the/a vacuum cleaner in my new flat yet.'

(ii) No, já jsem v novém bytě ještě VYSAVAČ nepoužil.

(iii) No, já jsem v novém bytě ještě nepoužil VYSAVAČ.

(iv) No, já jsem v novém bytě ještě NEPOUŽIL vysavač.

(32) a. (i) Jdeš s náma hrát na bubny? Už jsme všichni zvědaví na ten tvůj go.2SG with us play on drums already be.1PL all curious on the your buben, co sis nedávno vyhlídl na internetu.

drum which be.2SG-refl lately picked.out on internet

'Are you going to play the drums with us? We are all curious about your new drum you have picked out on the internet.'

(ii) Právě mi volal Marek, že vyráží do parku hrát s kamarády na just me called Marek that set.out.3SG to park play with friends on bubny.

drums

'Marek's just called me saying that he's about to go to the park to play the drums with his friends.'

b. (i) Rád bych se přidal, ale ještě se mi nepodařilo buben SEHNAT. glad would.1SG REFL joined but yet REFL me NEG.managed drum get 'I'd love to join you but I haven't managed to get myself the/a drum yet.'

(ii) Rád bych se přidal, ale ještě se mi nepodařilo BUBEN sehnat.

(iii) Rád bych se přidal, ale ještě se mi nepodařilo sehnat BUBEN.

(iv) Rád bych se přidal, ale ještě se mi nepodařilo SEHNAT buben. 
The role of givenness, presupposition, and prosody in Czech word order

(33) a. (i) Naše pracovní skupina je zatím výborná, jenom se zdá, že our working group be.3SG so.far outstanding only REFL seem.3SG that nám onemocněl náš architekt.

us fell.ill our architect

'Our working group has been outstanding so far but it seems that our architect fell ill.'

(ii) Naše pracovní skupina je zatím výborná, jenom minulý týden our working group be.3SG so.far outstanding only last week jaksi zmizeli všichni architekti. somehow disappeared all architects 'Our working group has been outstanding so far but last week all architects somehow disappeared.'

b. (i) Máš pravdu, tento týden už jsme tady architekta NEPOTKALI. have.2SG truth this week already be.1PL here architect NEG.met 'You're right, we haven't met the/an architect this week.'

(ii) Máš pravdu, tento týden už jsme tady ARCHITEKTA nepotkali.

(iii) Máš pravdu, tento týden už jsme tady nepotkali ARCHITEKTA.

(iv) Máš pravdu, tento týden už jsme tady NEPOTKALI architekta.

(34) a. (i) Před půl rokem jsem slyšel, že náš mládežnický orchestr začíná before half year be.1SG heard that our youth orchestra begin.3SG cvičit Haydnovu pátou symfonii. Nevíš, jestli už ji rehearse Hayden.poss fifth symphony NEG.know.2SG if already it predvedli? performed 'Six months ago I heard that our youth orchestra was going to start rehearsing Hayden's fifth symphony. Do you know if they have already performed it?'

(ii) Nevíš, jestli si náš mládežnický orchestr už troufnul na NEG.know.2SG if REFL our youth orchestra already dared to nějakou symfonii?

some symphony

'Do you know if our youth orchestra has ever dared to perform a symphony?'

b. (i) Podle mě ještě symfonii NEHRÁLI. according me already symphony NEG.performed

'In my opinion, they haven't performed the/a symphony yet.'

(ii) Podle mě ještě SYMFONII nehráli.

(iii) Podle mě ještě nehráli SYMFONII.

(iv) Podle mě ještě NEHRÁLI symfonii. 
(35) a. (i) Mezi oběma zeměmi se začínají vyhrocovat vztahy. Jeden between both countries REFL begin.3PL escalate relationships one kazažský diplomat prý nepokrytě kritizoval uzbeckou vládu.

kazakh diplomat allegedly openly criticized uzbek government 'The relationships between the two countries are beginning to escalate. Allegedly, one Kazakh diplomat has openly criticized Uzbek government.'

(ii) Mezi oběma zeměmi se začínají vyhrocovat vztahy. Diplomati between both countries REFL begin.3PL escalate relationships diplomats to ted' nebudou mít jednoduché.

it now NEG.will.3PL have easy

'The relationships between the two countries are beginning to escalate. Diplomats are now facing a rough time.'

b. (i) Jo, nedávno prý diplomata VYHOSTILI. yes recently allegedly diplomat expelled

'Yes, they say they expelled the/a diplomat recently.'

(ii) Jo, nedávno prý DIPLOMATA vyhostili.

(iii) Jo, nedávno prý vyhostili DIPLOMATA.

(iv) Jo, nedávno prý VYHOSTILI diplomata.

(36) a. (i) Vzpomínáš si na ten dárek, co minulý rok dostala naše dcera remember.2SG REFL on the present which last year got our daughter od Jindry? Předal jí ho tehdy osobně?

from Jindra handed.over her it then personally

'Do you remember that present our daughter got from Jindra last year? Did he give it to her personally?'

(ii) Slyšel jsem, že Jindra se vůbec nezajímá $\quad$ o svou heard be.1SG that Jindra REFL at.all NEG.be.interested.3SG about his

dceru. Ani se prý neobtěžuje dát jí sem tam daughter not.even REFL they.say NEG.bother.3SG give her every.now.and.then nějaký dárek.

some present

'I heard Jindra is not at all interested in his daughter. They say, he doesn't even bother to give her a present every now and then.'

b. (i) Pokud vím, minulý rok na Vánoce jí dárek POSLAL. as.far.as know.1SG last year for Christmas her present sent 'As far as I know, he sent her the/a present for Christmas last year.'

(ii) Pokud vím, minulý rok na Vánoce jí DÁREK poslal.

(iii) Pokud vím, minulý rok na Vánoce jí poslal DÁREK.

(iv) Pokud vím, minulý rok na Vánoce jí POSLAL dárek. 
The role of givenness, presupposition, and prosody in Czech word order

(37) a. (i) Kontrolovala jsem tu databázi měst a vesnic a viděla jsem, že controlled be.1SG the database cities and villages and saw be.1SG that nám tam pořád ještě chybí ta jedna jihomoravská vesnice. us there always still miss.3SG the one south.moravian village 'I was checking the database of cities and villages and I noticed that we're still lacking one south Moravian village.'

(ii) V té nové databázi prý musíme mít zahrnutá nejen města, ale in the new database they.say must.1PL have included not.only cities but i vesnice. Ale jak se tak dívám, tak tu nic nemáme. even villages but how REFL so look.1SG so here nothing NEG.have.1PL 'We have to include not only cities but also villages into the new database. But as I'm looking at it there is nothing like that.'

b. (i) To je zvláštní, Hanka mi tvrdila, že už vesnici ZAEVIDOVALA. that be.3SG strange Hanka me claimed that already village registered 'That's strange, Hanka told me she had already registered the/a village.'

(ii) To je zvláštní, Hanka mi tvrdila, že už VESNICI zaevidovala.

(iii) To je zvláštní, Hanka mi tvrdila, že už zaevidovala VESNICI.

(iv) To je zvláštní, Hanka mi tvrdila, že už ZAEVIDOVALA vesnici.

(38) a. (i) Nevím, jak dlouho to ještě budeme snášet. Musíme se toho NEG.know.1SG how long it still wil.1PL stand must.1PL REFL that potkana ve sklepě co nejdřív zbavit. sewer.rat in basement as.soon as.possible get.rid.of 'I don't know how much longer we can take it. We have to get rid of that sewer rat in the basement as soon as possible.'

(ii) Nevím, o čem to mluvišs. U nás ve sklepě přece nikdy žádní NEG.know.1SG about what it talk.2SG by us in basement still never any potkani nebyli. sewer.rat NEG.was 'I don't know what you're talking about. There have never been any sewer rats in our basement.'

b. (i) No, volal mi Jirka, že prý právě potkana OBJEVIL. well called me Jirka that they.say just sewer.rat found 'Well, Jirka called me and said that he had just found the/a sewer rat.'

(ii) No, volal mi Jirka, že prý právě POTKANA objevil.

(iii) No, volal mi Jirka, že prý právě objevil POTKANA.

(iv) No, volal mi Jirka, že prý právě OBJEVIL potkana. 
(39) a. (i) Už jsi slyšel to nové cédéčko od Talking Heads? Potřeboval already be.2SG heard the new CD by Talking Heads needed bych ho sehnat, mám na něho na př́ští týden psát would.1SG it get be.supposed.to.1SG on it next week write review recenzi.

'Have you already listened to the new CD by Talking Heads? I'd need to get one, I'm supposed to write a review of it next week.'

(ii) Tak konečně jsme $\mathrm{s}$ tou analýzou hotoví. Jen ted' nevím, jak so finally be.1PL with the analysis finished only now NEG.know.1SG how ti ty data předat. Nejlepší by to bylo vypálit, ale bohužel you the data give best would.3SG it was burn but unfortunately tu zrovna nemám žádné cédéčko.

here now NEG.have.1SG any CD

'So, we're finally finished with the analysis. I just don't know how to give it to you. The best would be to burn it out but unfortunately I don't have any CDs here.'

b. (i) Počkej, zeptám se bráchy, jestli náhodou cédéčko NEMÁ. wait ask.1SG REFL brother if by.chance CD NEG.have.3SG 'Wait, I'll ask my brother if he has the/a CD by chance.'

(ii) Počkej, zeptám se bráchy, jestli náhodou CÉDÉČKO nemá.

(iii) Počkej, zeptám se bráchy, jestli náhodou nemá CÉDÉČKO.

(iv) Počkej, zeptám se bráchy, jestli náhodou NEMÁ cédéčko.

(40) a. (i) Ta výstava se mi velmi líbí. Úplně jsem si zamilovala the exhibition REFL me very like.3SG completely be.1SG REFL fell.in.love.with tady tu koláž od Petry Mackové. Mohla bych se zeptat, kolik here this collage by Petra Macková could would.1SG REFL ask how.much stojí?

cost.3SG

'I like the exhibition very much. I've completely fallen in love with this collage by Petra Macková. Could I ask how much it is?'

(ii) Ta výstava se mi velmi líbí - hlavně jsem naprosto nadšená the exhibition REFL me very like.3SG especially be.1SG absolutely excited $\mathrm{z}$ tady těch koláží. Mohla bych se zeptat, $\mathrm{v}$ jakém rozmezí about here those collages could would.1SG REFL ask in what range se pohybují ceny? REFL fluctuated prices 'I like the exhibition very much - I'm absolutely excited about these collages. Could I ask what the price range is?'

b. (i) Moc mě to mrzí, ale bohužel vám nemůžeme koláž PRODAT. very me it be.sorry.3SG but unfortunately you NEG.can.1PL collage sell 'I'm really sorry but unfortunately we can't sell the/a collage to you.'

(ii) Moc mě to mrzí, ale bohužel vám nemůžeme KOLÁŽ prodat.

(iii) Moc mě to mrzí, ale bohužel vám nemůžeme prodat KOLÁž.

(iv) Moc mě to mrzí, ale bohužel vám nemůžeme PRODAT koláž. 
The role of givenness, presupposition, and prosody in Czech word order

\section{B.4 Experiment 2}

\section{Definite NP, given PP}

(1) a. Co dělají na chodbě ty tašky. Vůbec jsem nemohl projít. what do.3PL in hallway those bags at.all be.1SG NEG.could walk.through 'Why are the bags in the hallway? I couldn't go through.'

b. Promiň, když jsem přišel z nákupu, nechal jsem stát tašky NA CHODBĚ. sorry when be.1SG came from shopping left be.1SG stand bags in hallway 'Sorry, when I came back from the store I left the bags in the hallway.'

(2) a. Chtěli bychom začít jíst, můžeš prosím tě sklidit ty knížky ze stolu, wanted would.ıPL start eat can.2SG please.1SG you put.away the books from table nebo je budeš ještě používat? or them will.2SG still use

'We'd like to start eating, can you please put the books away from the table, or are you going to use them?'

b. Zeptej se Radky, myslím, že ona položila ty knížky NA STŮL. ask.2SG REFL Radka think.1SG that she put the books on table 'Ask Radka, I think she put the books on the table.'

(3) a. Hledám vrtačku, myslíš, že je ve sklepě? look.for.1SG drill think.2SG that be.3SG in basement 'I'm looking for a drill, do you think it's in the basement?'

b. Jo, včera jsem zanesl vrtačku DO SKLEPA. yes yesterday be.1SG took drill to basement 'Yes, I took the drill to the basement yesterday.'

(4) a. Proč stojí tvoje kolo na terase? why stand.3SG your bike at terrace 'Why is your bike at the terrace?'

b. Dneska jsem lakoval kolo NA TERASE. today be.1SG varnished bike at terrace 'I was varnishing the bike at the terrace today.'

(5) a. Nevíš kde máme brokolici? Díval jsem se do ledničky, ale NEG.know.2SG where have.1PL broccoli looked be.1SG REFL to fridge but nenašel jsem ji tam. NEG.found be.1SG it there 'Do you know where we have broccoli? I looked to the fridge but I didn't find it there.'

b. Myslím, že Maruška nedávala brokolici DO LEDNIČKY. think.1SG that Maruška NEG.put broccoli to fridge 'I think Maruška didn't put broccoli to the fridge.' 


\section{Definite NP, new PP}

(6) a. Tak jsme se právě vrátili z myčky. Auto už je umyté. so be.1PL REFL just came.back from car.wash car already be.3SG washed 'So we've just come back from the car wash. The car is washed.'

b. Měli byste ještě zavézt auto DO GARÁŽE. should would.2PL also take car to garage 'You should also take the car to the garage.'

(7) a. Právě volal brácha a ptal se, jestli mu můžeme přivézt kabát. just called brother and asked REFL if him can.1PL bring coat Nevíš, kde ho má? NEG.know.2SG where it have.3SG 'My brother has just called and asked if we could bring him a coat. Do you know where it is?'

b. Pokud vím, tak si brácha vždycky věší kabát DO SKŘíNĚ. as.far.as know.1SG so REFL brother always hang.3SG coat to closet 'As far as I know, your brother always hangs it in the closet.'

(8) a. Ty sis s sebou nebral čepici? I když je taková zima? you refl-be.2SG with yourself NEG.took cap even when be.3SG so cold 'You didn't take a cap? Even when it's so cold outside?'

b. Jsem fakt sklerotik, zase jsem si zapomněl čepici DOMA. be.1SG really forgetful.person again be.1SG REFL forgot cap at.home 'I'm really forgetfull, I forgot the cap at home again.'

(9) a. Za komunistů měla asi Olga a její syn dost těžký život. during communists had maybe Olga and her son very tough life 'During the Communist era Olga and her son might have had a tough life.'

b. To je pravda, věděla jsi, že Olga porodila syna VE VĚZENí? it be.3SG truth knew be.2SG that Olga gave.birth son in jail 'That's true, did you know that Olga gave birth to her son in jail?'

(10) a. Nevíš, kde je ten soubor s tou databází? NEG.know.2SG where be.3SG the file with the database 'Do you know where the file with the database is?'

b. Podle mě už ti Olda nahrál soubor NA POČíTAČ. according me already you Olda uploaded file to computer 'I think Olda has already uploaded it to your computer.'

\section{Indefinite NP, given PP}

(11) a. Včera V tesku předváděli nějaké úžasné pánve. yesterday in tesco presented some amazing pans 'Yesterday they were presenting some amazing pans in Tesco.'

b. Já jsem si nikdy nekoupil pánev V TESKU. I be.1SG REFL never NEG.bought pan in tesco 'I have never bought a pan in Tesco.' 
The role of givenness, presupposition, and prosody in Czech word order

(12) a. Viděl jsi ty hodinky, co měl Radim včera na pláži? saw you the watch that had Radim yesterday on beach 'Have you seen the watch Radim was wearing yesterday on the beach?'

b. Ne, ale nedávno jsem našel hodinky NA PLÁžI. no but recently be.1SG found watch on beach 'No, but I've recently found a watch on the beach.'

(13) a. Byli jste minulý rok $\mathrm{v}$ kostele na koncertě vánočních písní? were be.2PL last year in church in concert Christmas songs 'Did you go to the Christmas songs concert in church last year?'

b. Ne, ale tento rok budeme zpívat píseň $\mathrm{V}$ KOSTELE. ne but this year will.1PL sing song in church 'No, but this year we're going to sing a song in church.'

(14) a. Mobily by se podle mě měly $v$ tramvaji zakázat. cells would.3PL REFL accordding me should on tram ban 'I think using cell phones on trams should be banned.'

b. Mm, to je fakt... Jo a slyšela jsi, že Petra ztratila mobil V $\mathrm{hm}$ that be.3SG fact yes and heard be.2SG that Petra lost cell on TRAMVAJI? tram 'Hm, that's true...And have you heard that Petra lost her cell on the tram?'

(15) a. Nechápu, proč tak hrozně zanedbávají stromy v parku. NEG.understand.1SG why so terribly neglect.3PL trees in park 'I don't understand why they neglect trees in the park so much.'

b. No nevím, ale nedávno jsem viděl, jak sází strom V PARKU. well NEG.know.1SG but lately be.1SG saw how plant.3PL tree in park 'I don't know but lately I've seen people planting trees in the park.'

\section{Indefinite NP, new PP}

(16) a. Tak nevím, jak mám udělat tu omeletu, Roman zapomněl koupit so NEG.know.1SG how should.1SG do the omelette Roman forgot buy vajíčka.

eggs

'I don't know how I should make the omelette, Roman forgot to buy the eggs.'

b. Jsi si jistá, mám pocit, že jsem viděl vajíčko VE SPÍŽI.

be.2SG REFL sure have.1SG feeling that be.1SG saw egg in pantry

'Are you sure, I think I've seen an egg in the pantry.'

(17) a. Tak honem, obuj si boty, musíme vyrazit.

hurry up put.on.2SG REFL shoes must.1PL set.out

'Hurry up, put the shoes on, we have to go.'

b. Rád bych, ale brácha mi vyhodil botu Z OKNA.

glad would.1SG but brother me threw shoe out.of window

'I'd like to but my brother threw my shoe out of the window.' 
(18) a. Budeme potřebovat hodně kaštanů.

will.1PL need a.lot.of chestnuts

'We'll need a lot of chestnuts.'

b. Pavel už našel kaštan NA NÁMĚSTÍ.

Pavel already found chestnut.tree at square

'Pavel has already found a chestnut tree at the square.'

(19) a. Proboha, co se ti stalo se zubama?

for.god.poss.sake what REFL you happened with teeth

'For God's sake, what happened to your teeth?'

b. Nebudeš tomu věřit, ale včera mi někdo vyrazil zub VE RVAČCE.

NEG.will.2SG it believe but yesterday me somebody broke tooth in fight

'You won't believe it but yesterday someone broke my tooth in a fight.'

(20) a. Musíme rychle vyrazit, zbývají nám k naložení ještě nějaké kufry?

must.1PL quickly set.out remain.3PL us for loading still some suitcases

'We must go now. Is there still some luggage that needs to be loaded?'

b. Myslím, že jsem ještě viděl stát kufr V PŘEDSíNI.

think.1SG that be.1SG also saw stand suitcase in entrance.hall

'I think I've seen one more suitcase in the entrance hall.'

\section{B.5 Auxiliary experiment with pronouns}

\section{Definite contexts}

(1) a. Je Petrova pračka pořád ještě pokažená?

is Petr.poss washing.machine always still broken

'Is Peter's washing machine still broken?'

b. Ne, včera tu byl opravář a opravil ji. no yesterday here was repairman and repaired it

'No, a repairman came yesterday and repaired it.'

(2) a. Bolí tě ještě pořád zuby, nebo už jsi $s$ tou stoličkou něco hurt.3PL you always still teeth or already be.2SG with the molar something udělal?

did

'Do your teeth still hurt or have you already done something about that molar?'

b. Už je to lepší, v pondělí mi ji zubař vytrhl.

already be.3SG it better on monday me it dentist pulled.out

'It's better now, my dentist pulled it out on Monday.'

(3) a. Četl jsi už ten článek, který jsem ti doporučil?

read be.2SG already the article which be.1SG you recommended

'Have you read that article I recommended to you?'

b. Ještě ne, ale už jsem si ho v knihovně okopíroval.

yet not but already be.1SG REFL it in library copied

'Not yet, but I've already copied it in the library.' 
The role of givenness, presupposition, and prosody in Czech word order

(4) a. Dnes ráno s tebou chtěl mluvit správce domu. today morning with you wanted talk caretaker house 'The caretaker of the house wanted to speak to you this morning.'

b. Jo, už jsem ho potkal, všechno je vyřízeno. yes already be.1SG him met everything be.3SG arranged 'Yes, I met him and everything has been arranged.'

(5) a. Už jsi viděl toho psa, kterého si Zuzka přinesla z útulku? already be.2SG saw the dog which REFL Zuzka brought from dog.shelter 'Have you seen that dog Zuzka brought from the dog shelter?'

b. Jo, včera jsem ho se Zuzkou byl venčit - je úžasný! yes yesterday be.1SG it with Zuzka was walk be.3SG awesome 'Yes, I went to walk it with Zuzka yesterday - he's awesome!'

(6) a. Kam se ztratila ta hezká váza, kterou jste měli postavenou na where REFL disappeared the nice vase which be.2PL had put on kamnech?

stove

'Where did the vase you had on the stove disappear?'

b. Nedávno ji shodil náš pes, takže už je po ní. recently it knocked.over our dog so already be.3sG after it 'Our dog has recently knocked it over so it's gone.'

(7) a. Můžeš mi ještě jednou ukázat tu pohlednici, která ti přišla od bratrance can.2SG me once more show the postcard which you arrived from cousin

$\mathrm{z}$ Panamy?

from Panama

'Can you show me once more the postcard you got from your cousin from Panama?'

b. Bohužel už jsem ji vyhodil.

unfortunately already be.1SG it threw.out

'Unfortunately I threw it out.'

(8) a. Tak vidím, že univerzita není od tvého privátu až tak daleko. Jezdíš so see.1SG that university NEG.be.3SG from your flat not that far ride.2SG někdy na kole?

ever on bike

'So, I can see that the university is not that far from your flat. Do you sometimes ride a bike there?'

b. Ted' už ne, nedávno mi ho totiž ukradli.

now already no recently me it actually stole

'Not anymore, it has been stolen recently.'

(9) a. Ten dřez je už zas úplně špinavý.

this sink be.3SG already again really dirty

'The sink is really dirty again.'

b. To není možné, před chvílí jsem ho umýval.

it NEG.be.3SG possible before while be.1SG it washed

'It's not possible, I've just been washing it.' 
Šimík \& Wierzba

(10) a. Jaký byl $\mathrm{v}$ pátek pohovor $\mathrm{s}$ tou uchazečkou z Brna? how was on friday interview with the applicant from Brno 'How was the Friday interview with that applicant from Brno?'

b. Dobrý, všichni byli nadšení, takže jsme ji přijali.

good everyone was excited so be.1PL her accepted

'Good, everyone was excited so we gave her the job.'

\section{Indefinite contexts}

(11) a. Nevím, na co budeme dávat jídlo, vždyt' tady nejsou žádné talírée. NEG.know.1SG on what will.1PL put food actually here NEG.be.3PL any plates 'I don't know where we're going to put the food, there are no plates.'

b. To je zvláštní, já jsem je přinesl.

it be.3SG strange I be.1SG them brought

'That's strange, I brought them.'

(12) a. Marie tvrdila, že $\mathrm{v}$ žádném případě nechce na stole žádné květiny. Marie claimed that in any case NEG.want.3SG on table any flowers

'Marie said that in any case she doesn't want any flowers on the table.'

b. No to mě potěš, na co jsem je pak kupoval?

well it me cheer.2SG for what be.1SG her then bought

'No way, so what did I buy them for, then?'

(13) a. To snad není pravda, zase jsem si doma zapomněl tužku.

it may NEG.be.3SG truth again be.1SG REFL at.home forgot pencil

'That can't be true, I forgot my pencil at home again.'

b. Nemusíš se stresovat, můžu ti ji půjčit.

NEG.must.2SG REFL be.stressed can.1SG you it lend

'Relax, I can lend you one.'

(14) a. Zrovna ted' když mám naspěch, nemůžu najít ani jednu kancelářskou right now when have.1SG in.a.hurry NEG.can.1SG find not.a single office sponku.

clip

'Right now, when I'm in a hurry I can't find a single paper clip.'

b. Tak přijd' sem, můžu ti ji dát.

so come.2SG here can.1SG you it give

'So come here, I can give you one.'

(15) a. Tohle je fakt divný les, kráčíme tu už hodinu a ještě jsme this be.3SG really strange forest march.1PL here already hour and yet be.1PL nenarazili na žádnou houbu.

NEG.Come.1PL upon any mushroom

'This is a really strange forest; we have been walking around for an hour and we still haven't come upon any mushrooms.'

b. Taky mě to překvapuje, i když Máša ř́kala, že ji zahlídla. also me it suprise.3SG even when Máša said that it saw 'It suprises me too, even though Máša said she saw one.' 
The role of givenness, presupposition, and prosody in Czech word order

(16) a. Nevím, kam vyrazíme, tady v okolí bohužel moc barů NEG.know.1SG where go.1PL here in neighbourhood unfortunately many bars

není.

NEG.be.3SG

'I don't now where we're going to go, there aren't many bars around, unfortunately.'

b. Když jsem přicházel, tak jsem ho viděl.

when be.1SG came then be.1SG him saw

'When I was coming, I saw him.'

(17) a. Zdá se mi, že se letos přemnožili chrousti.

seem.3SG relf me that REFL this.year reproduced.excessively cockchafers

'It seems to me that the cockchafers have reproduced excessively this year.'

b. Aa, tak proto, když jsem šel pro vodu, tak jsem ho zašlápl.

oh so why when be.1SG went for water then be.1SG it trampled

'Oh, that's why; when I went to get the water, I trampled on it.'

(18) a. Viděl jsi, že Marta přinesla plnou tašku lískových ořechů?

saw be.2SG that Marta brought full bag hazel nuts

'Have you seen - Marta has brought a bag full of hazelnuts.'

b. Jo, už jsem ho snědl.

yes already be.1SG it ate

'Yes, I've already eaten it.'

(19) a. Na naší univerzitě se staví jako o život. Některé budovy vypadají at our university REFL build.3SG like for life some buildings look.like.3PL dost hezky.

very nice

'They have been furiously building new facilities at our university. Some of the buildings look really nice.'

b. Nějaký slavný architekt ji prý dokonce navrhoval.

some famous architect her they.say even suggested

'They say it was designed by a famous architect.'

(20) a. Na fakultě podle mě platí zákaz veškerých drog, včetně cigaret. at faculty according me be.valid.3SG ban all drugs including cigarettes 'In my opinion, there is a ban on all drugs including cigarettes at the faculty.'

b. A přesto když jsem minule vcházel k Machálkovi do kabinetu, tak ji even though when be.1SG last.time entered to Machálek to cabinet then it zrovna típal.

just stubbed.out

'Despite that, last time I entered Machálek's cabinet he was just stubbing one out.'

\section{Annotations for post-hoc confound analyses}

\section{Partitivity in experiment 1}

Concerning the indefinite conditions, is a partitive interpretation of the bare NP possible?

- YES: $2,7,10,12,16,25,30,33,35,37,40$ 
- NO: 1, 3, 5, 6, 8, 13, 14, 17, 19, 20, 21, 22, 23, 24, 28, 29, 31, 32, 34, 36, 38, 39

- BORDERLINE: 4, 9, 11, 15, 18, 26, 27

\section{Scope in experiment 1}

Concerning the indefinite conditions, is a wide scope interpretation of the bare NP with respect to negation possible?

- YES:

- NO: 2, 10, 19, 32, 33, 34, 40

- DOES NOT APPLY: 1, 3, 4, 5, 6, 7, 8, 9, 11, 12, 13, 14, 15, 16, 17, 18, 20, 21, 22, 23, 24, 25, $26,27,28,29,30,31,35,36,37,38,39$

Concerning the indefinite conditions, is a wide scope interpretation of the bare NP with respect to intensional operators possible?

- YES: 21, 28, 40

- NO: 3, 4, 19, 22, 23, 39

- DOES NOT APPLY: 1, 2, 5, 6, 7, 8, 9, 10, 11, 12, 13, 14, 15, 16, 17, 18, 20, 24, 25, 26, 27, 29, 30, 31, 32, 33, 34, 35, 36, 37, 38

\section{Indefinite readings in definite conditions in experiment 1}

Concerning the definite conditions, was the definite or an indefinite determiner preferred in the forced choice task (preferred $=$ chosen in at least $70 \%$ of the cases), or was there no preference at all?

- Indefinite determiner preferred: 3, 9, 14, 24, 27

- No clear preference: 2, 5, 13, 15, 22, 25, 33, 34, 35, 36, 38

- Definite determiner preferred: 1, 4, 6, 7, 8, 10, 11, 12, 16, 17, 18, 19, 20, 21, 23, 26, 28, 29, 30, 31, 32, 37, 39, 40

\section{Verb contrast in experiment 1}

Concerning the indefinite conditions, is verb contrast interpretation likely?

- YES: 6, 8, 9, 10, 11, 12, 14, 16, 17, 18, 20, 21, 22, 23, 24, 26, 27, 34, 36, 37, 38, 39

- NO: 2, 3, 4, 7, 13, 15, 19, 31, 32, 33, 40

- BORDERLINE: 1, 5, 25, 28, 29, 30, 35

Concerning the definite conditions, is verb contrast interpretation likely?

- YES: 2, 3, 8, 10, 11, 12, 14, 16, 17, 18, 20, 21, 22, 24, 27, 29, 31, 32, 34, 36, 37

- NO: $1,4,5,7,9,13,15,19,25,28,33,38,40$

- BORDERLINE: 6, 23, 26, 30, 35, 39 
The role of givenness, presupposition, and prosody in Czech word order

\section{PP contrast in experiment 2}

Concerning the PP-new indefinite conditions, is PP contrast interpretation likely?

- YES:

- NO: $36,37,38,39,40$

Concerning the PP-new definite conditions, is PP contrast interpretation likely?

- YES: 26, 27, 30

- NO: 28,29 